\title{
El desafío o problema nacionalista
}

\author{
Ignacio M. ${ }^{a}$ Beobide Ezpeleta \\ Catedrático de Derecho Constitucional \\ Universidad de Deusto
}

Resumen: Este trabajo pretende analizar las interpretaciones que los partidos políticos y la prensa en sus editoriales y comentarios hicieron sobre el planteamiento estratégico que el nacionalismo vasco - Partido Nacionalista Vasco y Eusko Alkartasuna - inició con la idea de culminarlo en la legislatura siguiente a las elecciones de 2004, una vez fracasado el llamado pacto de Estella de 1998 entre todas las fuerzas nacionalistas, políticas y sociales. Para el Partido Popular se trató de un desafío al Estado constitucional, que se agravaba por las alianzas de los socialistas con los nacionalistas y por la debilidad y división ideológica del socialismo. Para el Partido Socialista, el desafío lo había ya desarrollado la derecha española contra la democracia y las libertades, y la radicalización del nacionalismo era una de sus consecuencias. La prensa criticó la exageración de los partidos y defendió de manera expresa o tácita que el problema político en el País Vasco era el nacionalismo y que, si cabía hablar de reto, éste provenía de la violencia de ETA, de las relaciones con el resto del nacionalismo y de la nueva estrategia nacionalista.

Palabras clave: nacionalismo, prensa, elecciones, partidos políticos.

Abstract: This paper tries to analyse the explanations that political parties and newspapers - editorials and opinion articles - elaborated on the strategic approach that the Basque Nationalism -Partido Nacionalista Vasco and Eusko Alkartasunainitiated after the failure of the 1998 Estella Agreement between all nationalist forces, social and political, to be undertaken after the 2004 elections. According to the Partido Popular's view, it was about a challenge to the Constitutional State, aggravated by the alliance between the nationalist forces and the weakness and ideological division of socialism. In turn, the Partido Socialista considered that the Spanish Right had already challenged democracy and social and political liberties, and that the radicalisation of nationalism was just a consequence. The press criticised the immoderation of political parties and argued, expressly or tacitly, that nationalism was the political problem in the Basque Country and that, if there was a challenge, this came from ETA's violence, the relationships with the rest of nationalist forces and the new nationalist strategy.

Key words: nationalism, the press, elections, political parties.

Sumario: Introducción. - Las campañas del PNV, PSOE y PP en las elecciones generales de 2004. - La tragedia del 11 de marzo en Madrid: la aparente suspensión de la campaña._La línea editorial._Las colaboraciones: A) Comentarios anteriores al 11 de marzo; B) Comentarios a la tragedia del 11 de marzo. - Conclusiones. 


\section{Introducción}

El año 1998 trajo consigo un notable cambio en la política en el País Vasco. No fue un cambio ideológico, sino estratégico. Fue el nacionalismo en su conjunto el protagonista de ese cambio, que se concretó en la llamada Declaración de Estella - a la que se unió un partido que no se definía nacionalista, Izquierda Unida-EB - y en la tregua indefinida de ETA de 12 y 16 de septiembre. Estos dos acontecimientos, según los nacionalistas, habían permitido crear un momento histórico excepcional, debido a la agregación de las fuerzas nacionalistas y la exclusión de las no nacionalistas, que había que aprovechar de manera inmediata en las elecciones autonómicas de octubre del mismo año para realizar la paz y los objetivos últimos del nacionalismo.

La unidad de los firmantes del pacto se fundamentó en los siguientes criterios: la exclusión de los partidos no nacionalistas, la muerte por agotamiento de la Constitución y del Estatuto de Gernika; la defensa de la autodeterminación para conseguir la soberanía e independencia de Euskal Herria; las consecuencias integradoras para la sociedad vasca de las tesis nacionalistas y la difusión a la opinión pública de lo que Weber llamaba «el estado del sol naciente», es decir, la comunicación de una supuesta euforia e ilusión colectiva por el nuevo camino del pueblo vasco hacia su libertad.

Esta unidad influyó en la campaña de 1998; se redujeron enormemente los ataques entre los partidos nacionalistas y aumentaron las censuras a los partidos nacionales. Sin embargo, no pudieron evitarse las divergencias entre ellos. Mientras el PNV defendió que la tregua indefinida se convertiría necesariamente en definitiva, Batasuna lo puso en duda. Hubo, además - teniendo siempre en cuenta las manifestaciones y acciones de los protagonistas-, diferencias más profundas. PNV y EA entendieron que el proceso político a partir de la celebración de las elecciones debía comenzar por la paz y el fin de la violencia. Consolidada la paz y, siempre que quedara claro que la paz era obra del nacionalismo, éste estaría en condiciones de ir gradualmente a la realización de sus objetivos máximos. Esto dependía del éxito inmediato electoral. De este modo, la paz sería una paz nacionalista. Herri Batasuna, por el contrario, defendió que la paz y la soberanía eran la misma cosa o, más bien, dos aspectos de una misma realidad. La paz y la desaparición de la violencia serían la consecuencia de la soberanía y la independencia. Mientras ésta no fuera total no habría paz. Los pasos graduales hacia la soberanía acercarían a la paz, pero la paz sólo podía ser «soberana»y, mientras no lo fuese, la ausencia de violencia únicamente sería una concesión provisional y vigilada.

Este planteamiento de Lizarra fue un fracaso política y socialmente. $\mathrm{Ni}$ siquiera consiguió aumentar el número de escaños del bloque nacionalista. 
Se repitieron los resultados de las autonómicas anteriores de 1994: 41 nacionalistas $v$. 34. ETA volvió a asesinar a socialistas y populares, se rompió la unidad nacionalista, se demostró que la euforia era una invención de la clase política nacionalista, se deshicieron los pactos de gobierno y los nacionalistas tuvieron la tribuna pública de la campaña de las elecciones generales de 2000 para echarse mutuamente la culpa del fracaso. La razón esgrimida por ambas partes - PNV-EA y HB-ETA - fue la misma: el incumplimiento de los acuerdos. Ésta no fue la única cosa en común; también estuvieron de acuerdo en que el pacto fue valioso y lo seguía siendo y en que la unidad nacionalista era absolutamente imprescindible. Es decir, se mostraba la convicción de que sólo la unidad podía ser garante del éxito del nacionalismo ante el crecimiento de socialistas y populares en la década de los años noventa. Pero el fracaso de Estella demostraba que la unidad era mucho más difícil de lo que frívolamente se creía. El avance de los populares en las elecciones y la ausencia de HB dieron, de nuevo, el triunfo a los partidos de ámbito nacional en las elecciones generales de 2000, en las que el nacionalismo recurrió al derecho de autodeterminación y a la culminación del Estatuto de Gernika como pasos previos hacia la soberanía y libertad vascas.

A pesar de la desunión estratégica entre las fuerzas nacionalistas, todas ellas siguieron defendiendo los mismos puntos que les habían unido anteriormente. PNV y EA, en coalición en las elecciones autonómicas de 2001, incluyeron en su programa el respeto a las decisiones de la sociedad vasca, el reconocimiento del derecho a decidir su propio futuro, es decir, la autodeterminación, la federación de Euskadi y Navarra y la asociación con los territorios vasco-franceses, siempre con la intención de alcanzar en último término la soberanía nacional, aunque, a la hora de pedir el voto, moderaron su nacionalismo en busca del éxito electoral, que no llegaría.

El programa electoral de 2001 repetía el ideal del Pacto de Lizarra, cuando afirmaba que los fundamentos de la paz en el País Vasco eran el derecho a la vida y a la libertad individual, el diálogo político y el respeto a las decisiones de los vascos. De este modo, se repetía como en Lizarra que la consecución de los fines políticos nacionalistas eran la condición de la paz. Pero esta interpretación era la que, en su momento, hizo el abertzalismo de HB, no la que hizo el PNV. Según esto, el PP no andaba lejos de la realidad al decir que el PNV había radicalizado aún más su postura política. El orden estratégico no era ya primero la paz «nacionalista» y después la soberanía, sino el que defendió HB: primero, el triunfo político y, después o a la vez, la paz.

En 2001, pues, el Pacto de Lizarra, aunque parecía imposible, seguía siendo un desideratum nacionalista. La causa de la contradicción entre la unidad deseada y la división real la coalición nacionalista la basó en la violencia criminal de ETA, mientras que Batasuna la explicó por el rechazo del PNV y EA a la oferta de alianza para la construcción nacional y la soberanía. Pero el 
rechazo de ETA por su violencia no despejó todas las dudas sobre el posible apoyo de EH a la investidura de Ibarretxe. La misma condena de ETA y de su violencia se ensombrecía, cuando el PNV colocaba a ETA y al PP en los extremos del arco político vasco polarizando la oposición a un centro «nacionalista» $\mathrm{y}$ «demócrata» ocupado, fundamentalmente, por el PNV. Con este planteamiento se ocultaba la verdadera naturaleza del problema de Euskadi y se insinuaba la convicción, tantas veces dicha, de que ETA, por asesina que fuera, era una consecuencia del problema que sufría Euskadi.

El PP interpretó que los nacionalistas buscaban la reedición del pacto de Lizarra mediante una nueva tregua. El PNV, según esto, tendría elaborada una estrategia de convergencia con ETA y el objetivo popular era, por consiguiente, derrotar al régimen nacionalista. Para ello había que desalojar a los nacionalistas del poder. De la misma manera pensó el PSOE. El triunfo electoral de un PNV radicalizado traería consigo la potenciación del frente nacionalista. Las elecciones eran la ocasión para derrotar al fascismo, al fanatismo, a la intransigencia, a la impunidad y al miedo nacionalistas. El resultado de las elecciones de 2001 redujo las diferencias entre nacionalistas -40 escaños - y los demás partidos $-35-$.

La ilegalización posterior de $\mathrm{EH}$, que creó nuevas afinidades entre el PNV y los nacionalistas de EH bajo la fórmula de defensa de los derechos políticos de todos, la aprobación por el Parlamento Vasco de la falsamente llamada reforma del Estatuto - o plan Ibarretxe-, por su carácter netamente anticonstitucional y, sobre todo, el anuncio de que se sometería a referéndum en la siguiente legislatura, fuese cual fuese el resultado de su paso por las Cortes, permiten plantear el objeto de análisis de este trabajo: la interpretación que hicieron los partidos políticos y la prensa del planteamiento estratégico del nacionalismo vasco tal como aparece en las campañas de las elecciones generales de $2004^{1}$.

Los datos básicos de estas elecciones generales de 2004 fueron los siguientes (1. ${ }^{\text {er }}$ cuadro):

$$
\begin{array}{lrr}
\text { Censo electoral } \ldots \ldots \ldots \ldots & 34.571 .831 & \\
\text { N. }^{\circ} \text { votantes } \ldots \ldots \ldots \ldots \ldots & 26.155 .436 & 75,66 \% \\
\text { Abstención } \ldots \ldots \ldots \ldots \ldots & 8.416 .395 & 24,34 \% \\
\text { Votos válidos } \ldots \ldots \ldots \ldots \ldots & 25.891 .299 & 98,99 \%
\end{array}
$$

${ }^{1}$ Sólo se utiliza el periódico El Correo de Bilbao en su edición para Vizcaya. Para la introducción, ver mis trabajos: Rev. Estudios de Deusto; vol. 46/2, julio-diciembre 1998, «Elecciones al Parlamento Vasco de 25 de octubre de 1998»; vol. 48/2, julio-diciembre 2000, «Prensa y elecciones generales en Euskadi (12 de marzo de 2000)»; vol. 49/1, enero-junio 2001, «Comunidad Autónoma Vasca: Elecciones autonómicas del 13 de mayo de 2001. La coalición electoral nacionalista». 
En el segundo cuadro ${ }^{2}$ se pueden ver los resultados generales al Congreso:

\begin{tabular}{crrr}
\hline Candidatura & \multicolumn{1}{c}{ Votos } & \multicolumn{1}{c}{$\%$} & Diputados \\
\hline PSOE & 11.026 .163 & 42,59 & 164 \\
PP & 9.763 .144 & 37,71 & 148 \\
CIU & 835.471 & 3,23 & 10 \\
ERC & 652.196 & 2,52 & 8 \\
PNV & 420.980 & 1,63 & 7 \\
IU & 1.284 .081 & 4,96 & 5 \\
CC & 235.221 & 0,91 & 3 \\
BNG & 208.688 & 0,81 & 2 \\
CHA & 94.252 & 0,36 & 1 \\
EA & 80.905 & 0,31 & 1 \\
NA-BAI & 61.045 & 0,24 & 1 \\
\hline
\end{tabular}

En el tercer cuadro aparecen los resultados de las elecciones en el País Vasco, donde se disputaban 19 escaños:

\begin{tabular}{cccc}
\hline Candidatura & Votos & $\%$ & Escaños \\
\hline PNV & 420.980 & $34,19 \%$ & 7 \\
PSE-EE/PSOE & 339.751 & $27,59 \%$ & 7 \\
PP & 235.785 & $19,15 \%$ & 4 \\
EA & 80.095 & $6,57 \%$ & $1^{3}$ \\
\hline
\end{tabular}

La evolución en el País Vasco por bloques ${ }^{4}$, nacionales o de ámbito general y nacionalistas o de ámbito regional, tanto de votos (V) como de escaños (E) aparece en el siguiente cuadro:

${ }^{2}$ En este cuadro como en los siguientes sólo se tienen en cuenta los partidos que sacaron algún escaño.

3 Izquierda Unida-EB sacó 102.342 votos, pero no obtuvo ningún escaño.

${ }^{4}$ Los bloques los integran el Partido Socialista, el Partido Popular (o sus antecesores como Unión de Centro Democrático), IU (o antecesores como el Partido Comunista), por un lado, y, por el otro, el Partido Nacionalista, Eusko Alkartasuna, Batasuna (con sus diversos nombres) y, en su momento, Euskadiko Eskerra. El número de escaños a repartir fue de 21 hasta 1989. A partir de 1993 inclusive es de 19. Únicamente en 1993 el bloque ganador en escaños tuvo menos votos. 


\begin{tabular}{lrrrrrrrrr}
\hline & 1977 & 1979 & 1982 & 1986 & 1989 & 1993 & 1996 & 2000 & 2004 \\
\hline $\begin{array}{c}\text { B. nacional } \\
\text { V }\end{array}$ & 442.358 & 358.842 & 487.768 & 402.885 & 337.347 & 469.200 & 645.918 & 589.818 & 575.536 \\
E & 12 & 10 & 10 & 9 & 8 & 11 & 11 & 11 & 11 \\
\hline B. nacionalista & & & & & & & & & \\
V & 357.610 & 505.075 & 647.077 & 597.807 & 659.667 & 580.419 & 574.274 & 433.974 & 501.885 \\
E & 9 & 11 & 11 & 12 & 13 & 10 & 8 & 8 & $8^{5}$ \\
\hline
\end{tabular}

En primer lugar, desarrollo la campaña - dividida en dos partes, hasta la tragedia del día 11 de marzo en Madrid y la posterior hasta el día de las votaciones - de los tres grandes partidos en las circunscripciones vascas, PNV, PSE y PP, dejando para notas las campañas de EA y EB-IU; en segundo lugar, los editoriales; en tercer lugar, los comentarios, también separados en dos bloques, antes y después del día 11, y, por último, las conclusiones del trabajo.

La descripción de las campañas sigue un orden cronológico, que trata de transmitir no sólo los «mensajes» de los partidos, sino también el «masaje» - siguiendo la terminología conceptual de McLuhan - a que someten los políticos al electorado.

\section{La campaña del PNV}

Casi al final de la campaña el cabeza de lista del PNV por Vizcaya manifestó en una entrevista que el PNV no tenía nada que hacer en una campaña polarizada en torno a Rajoy y Zapatero, los candidatos del Partido Popular y del Partido Socialista a la presidencia del Gobierno de España. Algunos comentarios añadieron que esto ocurría a pesar de los intentos nacionalistas de abrirse un hueco en la campaña. Tal vez, sea más exacto decir que no tuvo sitio en la campaña, porque no existía ni conciencia de Estado, ni interés de Estado, ni política de Estado. Se trató de una campaña exclusivamente localista y nacionalista que, salvo alguna referencia difusa a posibles pactos con el partido ganador, se dedicó a reclamar al Estado reivindicaciones políticas y sociales, que se usaron, además, como instrumentos de ataque y censura contra los partidos nacionales. Fue lo más parecido a una campaña autonómica de elecciones al Parlamento vasco.

El eje de la campaña lo constituyó el objetivo de lograr un grupo «fuerte» en el Parlamento para conseguir el nuevo Estatuto - el «plan Ibarretxe»- en cuanto instrumento para la normalización política de Euskadi,

${ }^{5}$ http://www.elecciones.mir.es/MIR/jsp/resultados/index.htm, http://www9.euskadi.net/q93 TodoWar/q93Indice.jsp y elaboración propia. 
es decir, para su libertad y democracia nacionales, la autodeterminación y su identidad como pueblo y, también, para defender los intereses vascos económicos y de cualquier otro tipo ante la actitud contraria a la nación vasca de los grandes partidos, PP y PSOE, principalmente, el primero, que pretendían borrar la identidad del País Vasco.

El 55\% de las intervenciones estuvo dirigido contra los partidos políticos, destacando el ataque contra el Partido Popular con un 35\% y, en menor cuantía, el Partido Socialista y ETA-Batasuna con un $10 \%$ cada uno. El resto de la campaña, el 45\%, lo ocupó el programa electoral, en el que de manera abrumadora, el $30 \%$ del total de la campaña, sobresalió el proyecto político de reforma del Estatuto vasco. El horizonte político lo constituía la normalización política, concepto que contenía las reivindicaciones radicales nacionalistas que eran su conditio sine qua non de la paz definitiva. La campaña unió la presentación del proyecto político y la censura a los partidos políticos.

Después de una tensa precampaña, el presidente del PNV, Imaz, inició sus intervenciones con el anuncio de que descartaba pactos con Rajoy o Zapatero, a no ser que se abordase la normalización de Euskadi. El objetivo electoral era consolidar los 345.000 votos y 7 escaños conseguidos en las generales del 2000 para tener un grupo fuerte en el Congreso que pudiera impulsar el plan Ibarretxe. El PNV consideraría una buena noticia que el PP no repitiera mayoría absoluta, ante lo cual no cerraba ninguna puerta para la siguiente legislatura. Las premisas para llegar a acuerdos con cualquiera de los dos partidos nacionales eran la apuesta por el diálogo y la voluntad clara de resolver el problema de la normalización política de Euskadi. De momento, resultaba ser pura ficción pensar en pactos con Rajoy o Zapatero sobre la base de un proyecto compartido de normalización y un trabajo conjunto en favor de un nuevo Estatuto. De todos modos, en cualquier negociación el plan Ibarretxe estaría en cima de la mesa. Diálogo con todos los partidos y ayuda para la regeneración democrática tras la involución y la regresión autonómica del PP eran la oferta del nacionalismo, que se consideraba a sí mismo, y no a los socialistas, como la verdadera oposición al PP. En este sentido, el voto nulo propugnado por la ilegalizada HB eran votos perdidos que favorecían al Partido Popular. La comunicación entre partidos era imprescindible para hacer frente a la crispación y alcanzar un doble pacto entre vascos y con el Estado. Ibarretxe, por su parte, pidió a los electores que respaldasen el 14-M la eventual convocatoria de una consulta en la que los ciudadanos vascos pudiesen decidir su futuro sin ir a la cárcel ${ }^{6}$.

Esta presentación del contenido de la campaña se repitió en los días siguientes con pequeñas modificaciones. Así, en el primer mitin oficial de

${ }^{6}$ El Correo 27-2-04 (24 y 28). 
la campaña Arzalluz e Imaz justificaron la trascendencia de estar en Madrid en defender la nación vasca, su reconocimiento jurídico y su derecho a decidir en un eventual referéndum. Es decir, en Madrid era necesario un grupo «fuerte» para impulsar el plan Ibarretxe - la mayoría del tribunal constitucional, diría Ibarretxe, no estaba por la labor de paralizarlo - orientado a cerrar la transición en Euskadi - la primer transición, según Arzalluz, fue una enorme improvisación y una farsa - con un nuevo pacto con el Estado que garantizase el derecho de autodeterminación y el reconocimiento jurídico de la nación vasca. Prácticamente se dijeron las mismas cosas que en la presentación de la campaña. Lo que se añadió fue un intento de justificación del nuevo pacto, ya que el anterior se había quebrado con la actuación continua del Partido Popular de reducir el autogobierno vasco, de lo que sería un ejemplo el recurso interpuesto contra la ley universitaria vasca; por otra parte, lo que llevó a impulsar el texto del Estatuto fue la adicional que recogía una reserva de derechos históricos. La participación de Ibarretxe en este mitin destacó que la verdadera oposición al PP en Madrid la había hecho el Partido Nacionalista demostrando que los intereses vascos se podían defender con ideas y no con la violencia irracional e inhumana de ETA; así mismo, insistió en que PP y PSOE tenían que aceptar que existía un conflicto político más allá del terrorismo que exigía afrontarlo con el diálogo $0^{7}$.

Del mismo modo, Urkullu manifestó que tras cuatro años de mayoría absoluta, la presencia «fuerte» del PNV en Madrid era necesaria para preservar «la libertad, la democracia y la identidad como pueblo» de los vascos, cerrar la segunda transición y conseguir el derecho de los vascos a decidir su futuro. En Madrid se jugaba el plan Ibarretxe y se jugaba, también, la defensa de los intereses de Euskadi (afirmación esta última que se dijo en todas las elecciones desde 1977). La legislatura siguiente iba a ser (Imaz) la del reconocimiento nacional de Euskadi y creación de un nuevo modelo de Estado. Los votos que preocupaban al PP eran los que obtenía el PNV, no las papeletas inútiles que pedía Batasuna, sufragios no sólo perdidos, sino favorables para quienes intentaron destrozar políticamente a Carod Rovira y formar una nueva mayoría del PP. Las únicas novedades en el mensaje nacionalista fueron las de decir que el Estatuto se había desarrollado sólo gracias a los nacionalistas, la crítica conjunta al PP y PSOE, a quien se acusaba de seguidismo, y la afirmación de Olabarria de que el PP y PSOE habían gobernado juntos a través de siete pactos de Estado ${ }^{8}$.

La afirmación de la unidad de acción y de objetivos antinacionalistas del PP y el PSOE se repetiría en el acto del Kursaal en San Sebastián, donde

7 El Correo 28-2-04 (26).

8 El Correo 29-2-04 (34). 
previamente el PNV aludió a la división del nacionalismo y defendió que su oferta a $\mathrm{EA}^{9}$ para dotar de estabilidad a la coalición no buscaba la absorción de los por el momento «nuestros hermanos separados»; era necesario sumar para ser fuertes; las elecciones generales eran también «nuestras elecciones» y había que agruparse el 14-M; ETA no confiaba «en la gente de este país». Pero el centro de atención y descalificación en el Kursaal fue el ayuntamiento del PP y PSOE contra la nación vasca. Las críticas, que durante las semanas previas a la campaña fueron dirigidas contra el PP, ahora se hacían extensivas a los socialistas. Ibarretexe dixit: «Populares y socialistas son prácticamente lo mismo aquí»; son «los militantes del "no", del nunca jamás»; «su proyecto es el de diluir Euskadi como un azucarillo en el Estado español»; los dos grandes partidos rechazaban la nacionalidad vasca y cualquier propuesta que dijese que «aquí hay un pueblo, que tenemos derecho a decidir nuestro propio futuro y que lo podemos hacer a través de una consulta democrática sin ir a la cárcel». Ibarretxe jamás participaría en un proyecto de Estado que no reconociese «la nacionalidad y la nación vasca; esto es lo que tenemos que trasladar sin que nos tiemblen las

9 EA se presentó a las elecciones separada del PNV. Su campaña fue, también, netamente parroquial y localista con un carácter radicalmente nacionalista, como ha ocurrido habitualmente en sus campañas. Destaca su pretensión de diferenciarse del Partido Nacionalista y de Batasuna y su condición de partido de izquierda y socialdemócrata, independentista, soberanista, a favor de la autodeterminación (por ser nación y mejora del bienestar) y el derecho de los pueblos a ejercer la soberanía, garante del plan Ibarretxe (por la desconfianza hacia el PNV sobre la autodeterminación) y defensor de la pacificación y normalización en el sentido de la jerga nacionalista. Contrario a la violencia de ETA, cuya desaparición defendía, representaba una opción nacional vasca de izquierdas fundada en un concepto de nación cultural y lingüística. Su esquema de campaña fue similar al de la campaña del PNV, destacando más la crítica a los partidos que la exposición del programa. Puesto que disputaba el voto nacionalista, la preferencia de su crítica recayó sobre los nacionalistas (PNV, especialmente), aunque con una frecuencia parecida criticó al Partido Popular y a los socialistas - al PP, principalmente, por el recorte de derechos individuales y colectivos, criminalización del pueblo catalán, pueblo vasco y nacionalistas, y utilización (y utilidad objetiva) de la violencia de ETA - . El Correo informó diariamente de su campaña, aunque con menor extensión que la dedicada al PNV y, mucho menor, que la dedicada a los dos partidos nacionales. Su crítica al PP le llevó al extremo de afirmar sin ningún tipo de rubor, puesto que lo decía una nacionalista, Lasagabaster, que conocía las restricciones a la libertad de expresión que sufrían los no nacionalistas en el País Vasco, que la política de exclusión del PP había provocado que muchos ciudadanos necesitasen bajar la voz, cuando querían «manifestar opiniones contrarias al pensamiento único del PP» (El Correo 7-3-04, p. 36). Aralar también hizo campaña, pero la atención que le prestó el periódico fue prácticamente nula. En la poca atención que le prestó, Aralar manifestó que quería estar en el Congreso para que se reconociesen los sufrimientos de todas las víctimas, no sólo los causados por ETA, la mayoría, sino también los causados por las fuerzas policiales y parapoliciales. Su debate interno estaba centrado en la autodeterminación, la autonomía y la construcción nacional (Ver El Correo 3-3-04 p. 21 y 11-3-04 p. 23. Los contenidos de EA se encuentran en la sección diaria que El Corrreo dedicó a EA). 
rodillas». No había miedo al fracaso ni prisa, y la campaña era tan sencilla como aclarar si existía un pueblo vasco y si sus instituciones podían convocarle a una consulta. Imaz exageró demasiado al afirmar que el bipartidismo en Euskadi lo formaban el PNV, por una parte, y PP-PSOE, por la otra, y, también, exageró, dirigiéndose a Ibarretxe, al decirle: «Lehendakari, el nuevo Estatuto lo vamos a sacar adelante» ${ }^{10}$.

En Vitoria Imaz explicó que los socialistas habían pactado con el PP a lo largo de la legislatura medidas de involución democrática y recorte de libertades (hay que suponer que se refería a la Ley de partidos políticos y a la ilegalización de Batasuna) y habían dado gratuitamente a los populares los gobiernos de la Diputación de Álava y el Ayuntamiento de Vitoria. Por ello, el PNV era la única oposición y la garantía de la regeneración democrática y defensa del autogobierno. Además, el PNV era el único en defender los intereses de la sociedad vasca en Madrid. Los ejemplos eran la segunda pista del aeropuerto de Foronda, que el Ministerio y Aena obstaculizaban, porque había intereses en desarrollar una zona logística en Zaragoza, y el proyecto de la línea de alta velocidad del Gobierno del PP que exigía pasar por Madrid «para ir de Vitoria a Pamplona, a Logroño o a Barcelona». Esta era la alternativa del PP. ${ }^{11}$

En relación con las detenciones de miembros de ETA en Cuenca, la portavoz del Gobierno vasco manifestó su alegría, a la vez que preguntó a los que confiaban en la violencia si ése era al camino. La portavoz repitió lo dicho por Ibarretxe: «ETA asesina a los que se acercan a hablar con ella». Otras voces nacionalistas coincidieron en felicitarse por lo evitado, condenaron a ETA por secuestrar la voluntad popular, aprovecharon la ocasión para criticar a Acebes y, como en el caso de Aralar, manifestaron de manera cínica que la organización armada no sólo vulneraba los derechos humanos, sino que hacía del PP «el mayor beneficiario de sus actos» ${ }^{12}$.

En la visita a la margen izquierda, Anasagasti, que calificó alegremente la campaña de antidemocrática, porque estaba incitando al bipartidismo, repitió los argumentos conocidos para pedir el voto, añadiendo: «Si no hay una presencia nacionalista, no sólo sería un rodillo, sino que no habría una voz que marcara bien el terreno y la ideología de una organización surgida en este pueblo». Y, dado el lugar del acto de campaña, Imaz denunció la

${ }^{10}$ El Correo 1-3-04 (20).

11 El Correo 2-3-04 (24).

12 El Correo 1-3-04 (26). La frase lapidaria de Ibarretxe podía ser interpretada como defensa de la política del PNV de acercamiento al mundo radical y un intento de destacar el sufrimiento y el precio político que pagaban hombres políticos como Rovira y los nacionalistas vascos, a diferencia de populares y socialistas, en sus estrategias por superar la violencia. Esto era aprovechar el terrorismo de ETA para resaltar tanto la generosidad del PNV como la utilización ventajista que hacían de ella populares y socialistas. 
falta de voluntad del PP para defender a la empresas vascas, tales como La Naval y Babcok, y exigió más autogobierno y la presencia de las instituciones vascas para defender los intereses de estas compañías. Además, Imaz se puso por montera a la Unión Europea al decir: «No admitimos que exista una directiva que impide a La Naval no tener ayudas que sí tiene un astillero chino o coreano». Por otra parte, en respuesta a Rajoy por acusar al plan de Ibarretxe de intromisión en la voluntad de los navarros, defendió el respeto hacia tal comunidad y el compromiso de su partido de aceptar su decisión. No estaría mal, venía a decir con una argumentación falaz, que Rajoy desvelara si asumiría que el futuro de la sociedad vasca dependiese «exclusivamente de la voluntad democrática expresada por todos los ciudadanos» ${ }^{13}$.

De nuevo, Imaz insistió en que el verdadero bipartidismo era entre el PNV, por un lado, y el PSOE y el PP, por otro, de ahí que retara a ambos a un debate sobre la búsqueda de soluciones para Euskadi, basándose en la idea de que la sociedad vasca tenía derecho a saber qué plan tenían sobre la paz y la normalización política en Euskadi. La propuesta del PNV era el plan de Ibarretxe. La razón del bipartidismo era que ambos partidos nacionales seguían en Euskadi la misma estrategia. El único grupo que se había opuesto a la política de recortes de libertades del PP había sido el PNV. El presidente del PNV acusó al PP de meter miedo a los ciudadanos con la mentira de que con el plan Ibarretxe peligraban las pensiones. Era el último grito de guerra de un Mayor Oreja que metía la pata, mentía y trataba de difamar. La propuesta del Lehendakari al defender la gestión propia de la Seguridad Social redundaría en la mejora de las prestaciones sociales. El autogobierno (era el argumento no contrastado de todas las elecciones) traería más bienestar. El superávit del sistema de Seguridad Social y el INEM en Euskadi en los últimos cuatro años había sido de 2.321 millones. «Podríamos hacer - añadió - cinco Gugenheims al año» ${ }^{14}$.

Supuestos los ataques de Otegi a Imaz poniendo en duda su intención de seguir la pauta del soberanismo y, especialmente, las sospechas levantadas por aquél contra CIU por la supuesta filtración de la entrevista de Carod con ETA, el presidente del PNV salió en defensa de los firmantes del Pacto de Barcelona y en contra de Otegi, dando por perdidos los votos nulos pedidos por los abertzales e interpretándolos, además, como un apoyo a la estrategia de ETA. Otegi parecía, en su opinión, tener interés en atacar al nacionalismo catalán y vasco con lo que hacía una importante contribución a la campaña del PP. Imaz defendió, asimismo, el plan Ibarretxe como instrumento de desarrollo de un autogobierno renovado y abierto para decidir

13 El Correo 3-3-04 (21).
14 El Correo 4-3-04 (20). 
los vascos su futuro, enfrentarse a los retos de una Europa unida y a un mundo más globalizado, a la vez que ante representantes de la industria y el comercio valoró los logros del Estatuto y su encaje en la tradición pactista de los vascos. El plan Ibarretxe no sólo no suponía un inconveniente para el bienestar de los vascos, sino que con el apoyo de los presentes al acto podía encauzar una segunda transición y el reconocimiento de la nación vasca ${ }^{15}$.

No dio más de sí la primera semana de campaña. El programa del PNV para la segunda semana incluía una fuerte participación de Ibarretxe con el «plan» debajo del brazo como reclamo electoral. De momento, Ibarretxe volvió a acusar a Aznar de constituir un problema para que la Constitución europea fuese aprobada, e Imaz reivindicó, una vez más, mayor autogobierno, dada la falta de compromiso del gobierno central con Euskadi, tal como se demostraría en el tratamiento del problema de La Naval o de la regeneración de la bahía de Pasajes, y volvió a negar que el plan de Ibarretxe fuese secesionista. Lo que él quería era que las elecciones calibraran el plan, cuyos conceptos de ciudadanía y nacionalidad eran avalados por la mayoría del Parlamento catalán ${ }^{16}$.

En la celebración del centenario del nacimiento de José Antonio Aguirre hubo varias intervenciones que unieron la persona del primer lehendakari con la campaña y los propósitos del PNV. Ibarretxe lo hizo en plan humilde y heroico a la vez: nuevo marco político, consulta popular sobre su plan de nuevo Estatuto y traslado a Madrid para discutirlo con «cordialidad», aunque «cambien 100.000 leyes y quieran meter al lehendakari 300.000 veces en la cárcel». La democracia de los que, como el PP, se oponían ahora era similar a la de los que insultaron a Aguirre. Izquierda y derecha insultaban ahora al lehendakari como en la II República lo hicieron con Aguirre. «Nuestro pecado es ser demócratas y abertzales», porque los vascos buenos en Madrid eran los que renunciaban a decir que Euskadi era una nación. No importaba que ganase el PP o el PSOE, ya que los dos hacían lo mismo en Euskadi. Ambos se prestaban mutuo apoyo para impedir gobiernos nacionalistas en algunas instituciones locales y ambos acusaban al PNV de haber asumido las ideas de ETA. Imaz consideró que su partido era el de los herederos de aquella generación que defendió siempre la democracia y la libertad. El PNV merecería ser arrastrado por las calles, si no amparara los derechos humanos de todos. El momento actual era también de involución democrática, pero el PNV era el garante de la regeneración, del reconocimiento de la nación vasca y de su derecho a decidir. Ardanza (con los mismos silencios que sus correligionarios) dijo de Aguirre que «fue nacionalista por ser demócrata y se mantuvo leal a la democracia por

15 El Correo 5-3-04 (26).

16 El Correo 6-3-04 (24). 
ser nacionalista». No había que olvidar el caso para poder contrarrestar las críticas «falsas e injustas» contra el PNV. Pero Ardanza pidió a los suyos reproducir los comportamientos de un dirigente como Aguirre, «capaz de aglutinar a todos los demócratas de su tiempo en un Gobierno plural», que supo enfrentarse al totalitarismo. Ardanza alabó el talante profundamente democrático y tolerantemente nacionalista de Aguirre y aseguró que la nación cívica de ciudadanos libres defendida por Imaz enlazaba con una corriente que caracterizaba a los mejores hombres que había dado el $\mathrm{PNV}^{17}$.

En Vitoria, Ibarretxe dio su versión política de las pensiones y de las deudas del gobierno central con Euskadi. «Igual que la sanidad y la educación vascas son mejores que las españolas, cuando tengamos, y la tendremos, capacidad de gestionar y ordenar el sistema de pensiones en Euskadi, será mejor que el español». Todos los presentes lo verían, y socialistas y populares deberían aceptar la voluntad de los vascos. En cuanto a las supuestas deudas del gobierno central -60 millones de euros por los gastos del Prestige y 32 del Cupo - Ibarretxe (entre la ocultación y la insolidaridad) preguntó a sus oyentes si dejarían la gestión de sus cuentas corrientes en manos de «alguien que os quiere quitar el dinero para trasladarlo a no sé qué otras administraciones por capricho de algún ministro. Sólo faltaba que además de meter la mano para no trasladarnos competencias, nos metan también la mano en la cartera». Las promesas de Zapatero de no gobernar, si no era la fuerza más votada, no las creía teniendo en cuenta el apoyo socialista a los populares en la Diputación de Álava. Debía enmendar lo hecho en Álava, porque de lo contrario todo lo que dijera Zapatero iría «al cubo de la basura».

En el mismo acto de Vitoria, Imaz preguntó a Rajoy si la certeza que éste mostraba en el fracaso del plan de Ibarretxe se basaba en la manipulación de la justicia, «tapando la voz y la boca a una sociedad para que no pueda decidir sobre su futuro» o «metiendo en la cárcel al lehendakari». Las mismas acusaciones de manipulación de la justicia vertió al referirse a la tardanza del Tribunal Constitucional en definirse sobre la admisión a trámite del recurso presentado por Aznar contra el mismo plan ${ }^{18}$.

En el día de la mujer, Ibarretxe manifestó tener absolutamente claro que la igualdad de sexos suponía para él el proyecto político más grande del siglo XXI, «mucho más que nuestra propuesta de Estatuto», y confió en que Euskadi siguiese dando ejemplo en la lucha por la igualdad y fuese pionero en promover tal objetivo con un texto legislativo. Como «vasco, como hombre y como lehendakari» Ibarretxe se avergonzaba de que en Euskadi hubiese varones que maltratasen a sus compañeras. Para él, luchar por y

17 El Correo 7-3-04 (32).

18 El Correo 7-3-04 (19). 
para la libertad era hacerlo por la paz, la democracia y también para que hombres y mujeres fuesen iguales en dignidad. «Sólo un partido reaccionario como el PP - afirmó Emilio Olabarria - hace desaparecer políticas de igualdad» ${ }^{19}$.

La idea de que el PP era responsable de la crispación de la sociedad vasca la había defendido el PSE, pero en la segunda semana de campaña tanto los socialistas, por medio de Josu Montalbán, como el PNV, a través de Josu Erkoreka, culparon de lo mismo al PP. En esta ocasión ambos añadieron que el discurso del PP había llevado a la sociedad vasca a confundir violencia con independencia ${ }^{20}$.

La denuncia de Urquijo, del PP, sobre la utilización del término Euskal Herria y el plan Ibarretxe brindó el tema de las actuaciones de Ibarretxe e Imaz en Baracaldo, el corazón de Euskadi, según el lehendakari. La primera cuestión era una muestra de que el PP quería eliminar cualquier resto de identidad del País Vasco, «negar la cultura, la lengua y la nacionalidad vascas» con imposiciones destinadas a cosechar votos en España. Los franquistas querían dominar al pueblo vasco a través de la incultura e Ibarretxe puso como ejemplos que él tuvo que aprender el «Cara al sol» y se enteró de que el Nervión pasaba por Llodio gracias a que bajaba a la plaza del pueblo. Pero, a partir de entonces no habría ninguna generación de vascos que no pudiese conocer el euskera o la historia vasca. Este argumento permitía a Imaz pedir una «marea» de votos contra la imposición de quienes querían quitar el euskera de Navarra y «llenar Euskadi de bandera españolas, como si fuera la plaza de Colón» y, también, defender el plan Ibarretxe contra las críticas de fractura social y de empobrecimiento que llevaría su aplicación. Eran las acusaciones del miedo, de la mentira y de la manipulación. Para Ibarretxe las cuentas vascas de la Seguridad Social de los tres primeros trimestres de 2003 daban superávit. Ahora bien, el responsable del abandono de la margen izquierda era el $\mathrm{PP}^{21}$. En La Puebla de Arganzón, otro corazón de Álava y Euskadi según Imaz, prometió trabajar duro para que Treviño fuese Euskadi. Se iba a cumplir en pleno siglo XXI la voluntad de las personas de manera que Treviño sería lo que sus habitantes quisieran que fuera ${ }^{22}$.

Pedro Aspiazu, en la entrevista más arriba citada, repitió el guión de la campaña nacionalista, del que únicamente se podía destacar la presentación del plan Ibarretxe en el sentido de instrumento imprescindible para llevar adelante un nuevo modelo económico y social, aunque ignoraba el

19 El Correo 9-3-04 (20).

${ }^{20}$ El Correo 9-3-04 (22).

${ }^{21}$ El Correo 10-3-04 (20).

22 El Correo 10-3 04 (20). 
entrevistado qué se jugaba el plan en aquellas elecciones. Esta crítica al propio mensaje nacionalista acompañaba a otras afirmaciones carentes de rigor como la acusación a socialistas y populares de no haber contribuido al desarrollo autonómico o la de que el PNV nunca había abandonado las Cortes. La afirmación de que el Estado español era plurinacional y pluricultural las utilizó para justificar la organización territorial asimétrica conforme con las diferencias de identidad ${ }^{23}$.

Como final de campaña, Imaz leyó el «pliego» de argumentos del PNV: grupo «fuerte» en Madrid, garantía en el Congreso y en el Senado de los intereses de Euskadi, defensa del plan de Ibarrretxe, apuesta por el diálogo, mayor autogobierno, construcción de un país con todos y para todos, eje de la sociedad vasca, guardagujas de su convivencia, único capaz de aglutinar a la inmensa mayoría de los ciudadanos fuera de los extremos -ETA y $\mathrm{PP}-\mathrm{y}$ evitar el «choque de trenes». Entre sus críticas estaban la «violencia sin piedad de ETA», el uso partidista del terrorismo por parte del PP, el rechazo de Aznar y Zapatero a entrevistarse con Ibarretxe y la paralización de la «Y» ferroviaria. Anasagasti repitió alguno de estos argumentos y añadió el carácter de voto útil que tenía el voto al PNV. Su gran aportación fue decir que «a Madrid hay que ir a plantar cara, pero también a conseguir cosas». Ahora había que «trabajar para que fuesen 176» los que apoyasen el plan de Ibarretxe. Recordó el carácter pactista del PNV para apoyar su tesis de conseguir cosas en Madrid y alardeó del Concierto Económico, «la envidia del grupo catalán $»^{24}$.

El rechazo de ETA, que se recoge en el párrafo anterior y en otros lugares de la campaña, no se correspondía con las manifestaciones del juez Garzón, que reconocía la labor de la Guardia Civil y del Cuerpo Nacional de Policía en la lucha contra el terrorismo a la vez que mostraba la preocupación por el control, al menos aparente, que realizaban los políticos sobre la Ertzaintza. La dirección política de la policía vasca iba más allá de la mera utilización de una buena acción policial y, en ocasiones, suponía directrices concretas para no hacer algo. Garzón no criticaba a los agentes, que en algunos casos reconocían que tenían las manos atadas, sino a los mandos políticos. «Esto es grave y hay que exigir responsabilidades. A veces, la autoridad judicial debería tomar cartas en el asunto para exigir más», añadió el juez. El fiscal de la Audiencia Nacional Enrique Molina insistió en que la policía autonómica tenía una actitud tibia ante el terrorismo - sólo actuaba cuando ETA atacaba a uno de sus agentes - y veía a los fiscales y jueces de la Audiencia Nacional como personas non gratas. «En la lucha contra ETA - añadió - tenemos que trabajar con la Guardia Civil y

${ }^{23}$ El Correo 10-3-04 (24 y 25).

24 El Correo 11-3-04 (22). 
con la Policía, pero no con la Ertzaintza, porque no aporta ningún material investigador» ${ }^{25}$.

Naturalmente, todo esto, según la Consejería de Interior, no eran más que provocaciones. La sociedad vasca - decía en un comunicado oficial - conocía perfectamente el compromiso del Gobierno Vasco y de las personas que dirigían la Ertzaintza en su lucha contra el terrorismo. Los resultados de la lucha contra ETA serían mejores, si se dotara a la Ertzaintza de más medios y se le permitiese acceder a información en foros europeos. «Al señor Garzón - añadía la nota - al que no podemos tratar como juez cuando hace estas declaraciones sólo cabe decirle que ha esperado demasiado poco para entrar en campaña electoral. Es mucho mejor que deje las provocaciones para el $\mathrm{PP} \gg^{26}$.

En resumen, la petición de voto se apoyó en los argumentos, en primer lugar, de la nación étnica (mito de la nación) mediante la defensa del plan de reforma del Estatuto de autonomía y sus sucedáneos: plan de Ibarretxe, segunda transición en Euskadi, voluntad de normalización política, consulta o referéndum para decidir el futuro de los vascos, defensa de la nación vasca y su reconocimiento jurídico, nuevo modelo de Estado, pacto con el Estado a favor del derecho de autodeterminación, libertad, democracia e identidad como pueblo; en segundo lugar, en la virtud nacionalista (mito de la superioridad moral) supuestamente demostrada en la historia y en la actualidad: ser demócratas y nacionalistas a la vez, defensa constante de la democracia y libertad de la generación de la II República, ser nacionalista por ser demócrata y lealtad a la democracia por ser nacionalista de José Antonio de Aguirre; en tercer lugar, en la eficacia del nacionalismo (otra faceta del mito de la superioridad): defensa exitosa de los intereses de Euskadi en Madrid, mayor bienestar logrado por el Gobierno Vasco en sanidad, educación y pensiones que en España; en cuarto lugar, en la falsificación de la realidad: necesidad de regeneración democrática y de superación de la crispación política tras la involución y regresión autonómica del Partido Popular, calificación de la transición a la democracia de farsa e improvisación, ruptura del Estatuto de Gernika y de su autogobierno, justificación del nuevo Estatuto a través de la primera disposición adicional de la Constitución, bipartidismo entre PNV $v$. PP-PSOE, presentación del PNV como única oposición en las Cortes, política de riesgos ante ETA, mayor bienestar de los vascos, construcción de un país con todos y para todos, idea de un PNV como único capaz de aglutinar a la inmensa mayoría de la sociedad vasca, interpretación de ETA y PP como los extremos de la sociedad política vasca, negación del carácter secesionista, tendencialmen-

25 El Correo 28-2-04 (34).

${ }^{26}$ El Correo 28-2-04 (34). 
te, al menos, del plan Ibarretxe, calificación de involución democrática del momento electoral, nación cívica vasca de la nueva dirección del PNV, solidaridad y justicia nacionalistas, manipulación de la justicia, responsabilidad socialista y popular en materia de crispación de la sociedad vasca y de la identificación de violencia con independencia, identificación entre populares y franquismo, condición profundamente democrática e imprescindible del plan Ibarretxe para llevar a cabo un nuevo modelo social y económico, carácter plurinacional del Estado español, interpretación de la campaña como antidemocrática por incitación al bipartidismo, afirmación de que el PNV nunca había abandonado las Cortes; y, en quinto lugar, en la definición del enemigo: pretensión popular y socialista de eliminar la identidad del País Vasco, su cultura, lengua y nacionalidad, identidad entre PP y PSOE en su lucha contra Euskadi y la nación vasca, y defensa de que el voto nulo a HB favorecía la estrategia de ETA y, en consecuencia, fortalecía al Partido Popular.

\section{Campaña del PSE-PSOE}

El eje de la campaña socialista destacó que los males y las consecuencias negativas de ocho años de gobierno popular - mentiras, fortalecimiento y radicalización del nacionalismo, debilitamiento del constitucionalismo en Euskadi, prepotencia, soberbia, clientelismo, involución política, regresión social, disgregación territorial, manipulación del terrorismo, pérdida de las libertades y derechos - exigían la suma de todos los esfuerzos y votos de los demás partidos en torno al Partido Socialista para impedir una nueva victoria del Partido Popular. La conclusión objetiva que cabe extraer de su campaña coincide con lo expresamente anunciado por los socialistas, cuando afirmaron que había que ganar al PP, pero «los socialistas solos no podremos. Necesitamos de todos los autonomistas y progresistas, de todas las gentes de izquierdas, de los vasquistas e incluso de los nacionalistas que saben que lo peor que nos podría suceder a todos son cuatro años más de gobierno del $\mathrm{PP} \gg^{27}$. Esta petición de ayuda a los nacionalismos no podría

27 El Correo 5-3-004 (28). Desde el comienzo de la campaña IU se sintió acosada por el PSOE por la petición que éste hacía del voto progresista de izquierda y del voto útil. Por ello y porque el PP no habría podido desarrollar su peor política, según IU, si no hubiese recibido el apoyo socialista, una buena parte de su campaña se dirigió contra el PSOE. En la censura a los socialistas, Madrazo fue el más agresivo, contradiciendo en algunas ocasiones la mayor mesura de Llamazares. La distribución de la campaña de IU fue la siguiente: el $27,2 \%$ para programa y proyecto político; el $72,72 \%$ para los partidos políticos, destacando el PP con el 43,18\%, después el PSOE con el $25 \%$ y el PNV con el resto. El proyecto político principal era el de exportar el modelo catalán y vasco de gobierno plural y de izquierda al 
haberse hecho con un enfrentamiento radical con el nacionalismo vasco tal y como se desarrolló en las elecciones autonómicas de 2001. La alianza con los nacionalismos se veía necesaria para ganar al PP, de ahí que había que tratar al nacionalismo de otra manera e interpretar, al menos estratégicamente, su radicalidad como una consecuencia del radicalismo del PP. No obstante lo dicho, el PSOE mantuvo un claro rechazo de lo que constituía el centro de la campaña del PNV, el plan Ibarretxe, aunque con una cierta incoherencia en su argumentación.

La campaña socialista dedicó el 38,18\% de sus intervenciones a exponer su proyecto político - en bastantes ocasiones expuesto en contraposición a lo hecho por el Partido Popular-, mientras que la crítica a los partidos políticos alcanzó el 61,8\%, siendo el Partido Popular con un 47,27\% del total de la campaña el más censurado y descalificado. De este modo, el Partido Socialista, censurado como se ha visto por el nacionalismo, se sumó a todos los demás partidos, nacionales o nacionalistas en un ataque general contra el PP.

Los partidos de ámbito general o nacional, a diferencia de los partidos nacionalistas, se movieron en dos frentes. El primero abarcaba las cuestiones nacionales y el segundo, las autonómicas. En el primero destacaba la participación del candidato a presidente del gobierno y en el segundo, la de los políticos locales. En el caso del partido popular y en relación con el frente autonómico, la participación de Mayor Oreja fue de manera destacada la más importante. Esto dio mayor unidad a las intervenciones. Sin embargo, en el caso socialista el trabajo autonómico no estuvo dominado por una persona. Los partícipes menudearon las cuestiones y aumentó el riesgo de que algunos dijeran cosas de su propia cosecha, como, por ejemplo, la atribución al PP de la radicalidad del nacionalismo vasco. A continuación, expondré la alternativa socialista al gobierno del PP acompañada simultáneamente de la crítica al PP.

El comienzo de la campaña fue un ejemplo del uso de la descalificación. Mayor Oreja fue calificado (José Antonio Pastor), para empezar, de carroñero, desvergonzado y de usar y abusar de ETA y la Constitución para

gobierno central antes de que el PP - reaccionario, retrógrado, afín al OPUS, extremista, corrupto, secta nacional-católica apoyada por la Conferencia Episcopal y los Legionarios de Cristo- consolidara un Estado neofranquista y rechazara la democracia, la justicia social y el diálogo. Pero «la única alternativa al PP — dijo Llamazares en El Correo 4-3-04, p. 24 - no es el PSOE, es una coalición de izquierdas en su diversidad, en su pluralidad». El PSOE no tenía autoridad, ni credibilidad, ni legitimidad para pedir el voto progresista de la izquierda. Madrazo hacía suya la opinión del PNV de identificar a socialistas y populares, salvo en los momentos de campaña electoral. Además de una oferta generosa, casi irresponsable de su programa, IU defendía el Estado federal, el referéndum sobre la república y -la versión vasca de IU - el derecho de autodeterminación del pueblo vasco. (Ver para estos contenidos la sección diaria que El Correo dedicó a IU durante la campaña). 
obtener ventajas políticas. El Partido Socialista (Manuel Huertas), por su parte, estaba por la labor de enterrar el pensamiento único del PP, a quien pensar de diferente manera le parecía inconstitucional. Su cada vez más ofensivo estilo, la pretensión de alcanzar el poder a cualquier precio, la utilización del terrorismo como arma electoral, su falta de homologación con la derecha europea, la posibilidad de una Euskadi distinta con un pacto interno y la concertación con el Estado en lugar del enfrentamiento institucional del momento exigían que el PP pasara a la oposición ${ }^{28}$.

A esto añadía Patxi López que el PP dinamitaba cualquier posibilidad de estar todos juntos frente a ETA por razones puramente electorales, así como que manipulaba en beneficio propio el pacto antiterrorista. Sólo existían dos opciones electorales decía Lentxu Rubial: la de ahondar en la involución política, la regresión social y la disgregación territorial o la apuesta por la España de las libertades y de los consensos básicos. El País Vasco no podía ser un botín electoral del nacionalismo ni debía servir, tampoco, para tapar las vergüenzas de la derecha española ${ }^{29}$.

Por tanto, frente al inmovilismo, manipulación y resignación de Rajoy, Zapatero se presentó como el presidente de las reformas y de la solución de problemas como la vivienda o la precariedad laboral. Sería un presidente que retiraría las tropas españolas de Irak, si la ONU no se hiciere cargo de la situación (de hecho no se respetó este criterio), o que iría a Estados Unidos para reunirse con Kofi Annan en lugar de con Bush. El PSOE estaba cerca de la victoria electoral. Bastaba un último empujón, idea que se repetiría muchas veces a lo largo de la campaña ${ }^{30}$.

En un día dedicado prácticamente a atacar al PP, Zapatero, en respuesta a la acusación de Rajoy de que no tenía convicciones, manifestó que las suyas eran el no matarás (frente a la guerra injusta de Iraq), no mentirás (por el caso del Prestige), no robarás (caso de malversación de fondos del presidente de Castellón del PP) y no tolerarás abusos sexuales a menores (por el caso del alcalde de Toques) ${ }^{31}$. En la versión vasca de la campaña calificaron al PP de inmoral por pedir los votos socialistas dados a Nicolás Redondo en anteriores elecciones y de responsable de una política que quebraba la convivencia en Euskadi. Una legislatura más en manos de la derecha podría provocar tal lesión de los elementos vertebradores de la convivencia que sería difícil recuperarla. Aznar era el responsable del empeoramiento de

${ }^{28}$ El Correo 27-2-04 (27). En un acto conjunto Ramón Jáuregui y Josu Jon Imaz coincidieron en hacer un llamamiento a recuperar el diálogo político y superar la confrontación que aquejaba a la política vasca deteriorada por una «incomunicación personal y política» (p. 28).

29 El Correo 28-2-04 (29).

30 El Correo 28-2-04 (25).

31 El Correo 29-2-04 (30). 
la convivencia en Euskadi hasta límites «nunca conocidos». «En términos de diálogo y concordia estamos mucho peor que hace ocho años». El PP no tenía más discurso que el del terrorismo; por ello Mayor Oreja estaba encantado con la violencia que le permitía sacar votos fuera de Euskadi. La estrategia antinacionalista de Mayor era una excusa para que los socialistas no llegasen al poder. Los socialistas no estaban dispuestos a olvidar después de las elecciones los insultos y calumnias que estaban recibiendo por parte del $\mathrm{PP}^{32}$.

Patxi López, en un homenaje al disparate, aumentó la visión negativa de la obra del PP en Euskadi, cuando pidió el voto para acabar con la etapa del «no diálogo» y de la confrontación permanente, que había sumergido al País Vasco en «la crisis política más preocupante de su historia y que (había) perjudicado a la convivencia entre vascos de manera irresponsable». Una victoria socialista permitiría abrir una ventana a la regeneración democrática, a la recuperación de los derechos y libertades y al diálogo que PP y PNV no habían sabido desarrollar ${ }^{33}$.

La interpretación de Acebes de que había una secuencia de hechos entre la reunión del político catalán con ETA, el anuncio de la tregua en Catalauña y la furgoneta-bomba contra Madrid le llevó a felicitar a Carod Rovira, porque el atentado no se iba a celebrar en Cataluña. La solución de la lucha contra ETA, añadió, no estaba en la negociación, sino en la «eficacia de las fuerzas de Seguridad y la cooperación internacional». Carod Rovira calificó a Acebes y otros miembros del PP de miserables y malévolamente mentirosos e insinuó que lo que querían era un atentado. José Montilla, por su parte, calificó al ministro de Interior de «portavoz de una pandilla de mentirosos y de personas sin escrúpulos», que anteponían «sus miserables intereses a los de la mayoría y a la unidad de los españoles». El candidato

32 El Correo 29-2-04 (35). Las mismas acusaciones aparecen en El Correo 3-3-04 (22).En un tono distinto al practicado hasta el momento, pero no menos crítico y repetitivo en algunas cuestiones, Antonio Gutiérrez rechazó la política económica popular, con la que se había perdido una gran ocasión al apostar sólo por la especulación en el sector inmobiliario y despreciar el desarrollo tecnológico; el trabajo industrial había descendido un 2,5,\% y la inversión 24 puntos, mientras en Europa sólo había descendido 2 puntos, y el crecimiento de la productividad había descendido del 1,5\% al 0,5\%; asimismo, rechazó la política internacional por la guerra de Irak y el enfrentamiento a otros países europeos, el modelo de educación por clasista y la falta de respeto a las ideas de los demás (El Correo 1-3-04 (19 y 21)).

33 El Correo 1-3-04 (19 y 21). Casi en el mismo sentido se expresó Jesús Eguiguren en El Correo 2-3-04 (28), donde también aparece la política de promesas hacia el nacionalismo de Manuel Huertas: traspaso de todas las políticas activas de empleo a la comunidad vasca en el supuesto del triunfo de los socialistas para realizar, así, el desarrollo del bloque socioeconómico del Estatuto de Gernika, y, además, fortalecimiento, en general, de la contratación indefinida y la estabilidad en el empleo frente a la política del PP, que estimulaba el trabajo precario y mal remunerado. 
socialista, Rodríguez Zapatero, pidió que no se utilizara el terrorismo como arma electoral ${ }^{34}$.

De nuevo, Zapatero siguió el modelo de presentar en paralelo la crítica a un nefasto PP y su promesa de gobierno. Salvo la implícita relación entre la debilidad de Rajoy y la fortaleza de Zapatero, el resto de paralelismos fue explícito: manipulación e insulto del anterior gobierno versus un gobierno que diga la verdad; especulación con la vivienda y las ilusiones de los jóvenes frente a todo lo contrario; engaños, demagogia y beneficios para los especuladores urbanísticos en torno al trasvase de agua a Murcia frente a aportación de agua sin dividir y sin engañar; y despreocupación por el medio ambiente frente a la estricta aplicación del tratado del Protocolo de Kioto ${ }^{35}$.

Si bien los socialistas tenían un programa social para los jóvenes -igualdad de derechos para las parejas homosexuales, paridad europea de la edad de emancipación, agencia pública de alquiler de vivienda, mejora de las becas, reconstrucción del puente entre las aulas y el mercado - su presentación también se hizo por contraposición al Partido Popular. Tales objetivos eran los que se oponían a las propuestas retrógradas del «rancio clero español y de su brazo político, el PP», según el candidato Eduardo Madina. Y siguiendo la pauta de la acusación, Arantza Mendizábal defendió que el PP era incluso culpable de generar un «peligroso antinacionalismo en toda España y antiespañolismo en los nacionalistas» catalanes y vascos, además de utilizar el País Vasco como botín electoral. La irresponsable radicalización del nacionalismo gobernante se oponía a la idea de la compatibilidad entre el concepto de España y de Euskadi de los socialistas. Ante la peor división de los últimos tiempos, la reconciliación exigía la recuperación del diálogo institucional entre los gobiernos central y vasco, una mayor colaboración entre las Fuerzas de Seguridad del Estado y la Ertzaintza y una respuesta común de todos los partidos democráticos ante la violencia de $\mathrm{ETA}^{36}$.

Por tierras de Euskadi Javier Rojo ofreció a los partidos democráticos abandonar hostilidades y hostigamientos para lograr zonas de entendimiento, ahora que se estaba ganando al terrorismo. A pesar de que dijo que la campaña electoral se había convertido en un monólogo sobre el terrorismo, como si no hubiese problemas de vivienda, sanidad o educación, destacó la

34 El Correo 1-3-04 (26).

35 El Correo 3-3-04 (20). En una intervención en el Forum Europa Rodríguez Ibarra hizo responsable al gobierno de que los españoles dudasen por primera vez de la veracidad de las informaciones policiales contra ETA por el uso electoral que se hacía de las mismas. El PP conducía a España a un callejón peligroso al utilizar el terrorismo en la campaña y dudar de la lealtad de los socialistas hacia el pacto antiterrorista con la única finalidad de ganar votos (El Correo 3-3-04 (20)).

36 El Correo 3-3-04 (22). 
importancia de las últimas detenciones de miembros de ETA, pero censuró su utilización en la campaña. Asimismo, se felicitó de la ilegalización de Batasuna, que había permitido, por ejemplo, al municipio de Llodio, donde hablaba, ganar en normalidad democrática. En el mismo tema y con las mismas felicitaciones, en este caso a la Guardia Civil, insistió Rubial en hablar de terrorismo, pidiendo explicaciones al gobierno por la extrañeza de las detenciones en cuestión. La oradora respondía a las acusaciones de Acebes contra Carod Rovira que mucha gente independentista no apoyaba la violencia en este país ${ }^{37}$.

Zapatero realizó un ataque muy personal contra Rajoy: un mal gobernante - redujo las becas, congeló los sueldos de los funcionarios públicos, redujo el número de efectivos policiales, abandonó a los voluntarios y marineros del Prestige y justificó la guerra de Irak con mentiras -, peor candidato y un enchufado para presidente de gobierno sin haber peleado por ello. Mientras el PP pactó con Bush, los especuladores y los amigos de las empresas privatizadas, Zapatero se uniría a la mayoría de españoles a los que el Gobierno del PP despreció y mintió con las armas de destrucción masiva, con la LOU o la política de vivienda. Defendió los debates en TV, desautorizó la encuesta del CIS como mentira, se comprometió en la lucha por la igualdad de derechos de las mujeres y prometió la regularización de los inmigrantes en situaciones de explotación o contratación irregular ${ }^{38}$.

Patxi López, aparentemente dolido por la acusación de Mayor Oreja de imitar a Arzalluz en sus insultos al PP, replicó que «usted se llama Jaime Mayor Oreja y que es clavadito a Jaime Mayor Oreja, el que pierde elecciones, el que llega tarde o no llega a los sitios más importantes, el que drogaba a los inmigrantes para meterlos en un avión, el que ha aglutinado y fortalecido al nacionalismo como nadie y el que intenta constantemente dividir y debilitar al constitucionalismo en Euskadi». El PP representaba al pasado y a la derecha más rancia. Después de haber gobernado con prepotencia y soberbia y haber enriquecido a sus amigos, el lugar que le correspondía era el de la oposición. El Gobierno de Aznar había utilizado la Justicia, los medios de comunicación y la lucha antiterrorista en beneficio propio. Ahora se trataba de hacer posible la remontada al PP, pero «los socialistas solos no podremos. Necesitamos de todos los autonomistas y progresistas, de todas

37 El Correo 4-3-04 (22).

38 El Correo 5-3-04 (24). Ver para semejantes descalificaciones El Correo 3-3-04 (22) y 6-3-04 (28). El CIS en su sondeo preveía una ajustada mayoría absoluta para el PP (176 escaños) y un leve ascenso del PSOE (131), 10 IU, 12 CIU, 7 PNV, 6 ERC y otros. En el País Vasco los resultados serían: 7 PNV, 7 PP, 4 PSE y 1 EA. La abstención rondaría el $46 \%$ en Guipúzcoa, 40,6 \% en Vizcaya y 29,2\% en Álava.- 
las gentes de izquierdas, de los vasquistas e incluso de los nacionalistas que saben que lo peor que nos podría suceder a todos son cuatro años más de Gobierno del PP». Arantza Mendizabal acusó, incluso, al PP de provocar frustración y desengaño entre su propia gente, en concreto, entre la burguesía de Neguri, que se habría sentido agredida por la política popular de establecer un control centralizado del poder económico ${ }^{39}$.

Las propuestas socialistas de mejoras en las pensiones - subsidios superiores al IPC para las pensiones mínimas, nueva regulación de los trabajadores autónomos dependientes y emprendedores, compromiso de destinar 4.000 millones de euros a la mejora de las pensiones - acompañaron a la crítica al plan Ibarretxe por poner en riesgo la viabilidad del sistema público de protección social y a la denuncia de que «el afán aventurero y rupturista del nacionalismo no podía poner en riesgo nuestra seguridad económica» ${ }^{40}$.

Arantza Mendizábal daba por seguro en una entrevista el triunfo de Zapatero ante un candidato flojo como Rajoy y explicó que el proyecto socialista para España era la cohesión en la pluralidad. A la entrevistada le aterraba una España única y homogeneizada. El constitucionalismo de los socialistas no era inmovilismo ni frentismo contra el nacionalismo. Si a los nacionalistas no les gustaba la Constitución, debían buscar fórmulas de cambio dentro de las reglas del juego. «Pero nosotros no estamos por el choque de patrias. En este sentido, el frentismo está roto. El futuro es la reconciliación de la sociedad vasca... Lo primero que me gustaría aclarar es que en los años en que gobernó el PSOE el nacionalismo se moderó y tuvimos el pacto de Ajuria Enea, mientras que en los años de gobierno del PP el nacionalismo se ha radicalizado y estamos en Estella... Eso, porque aquí unos hemos jugado a moderar al nacionalismo y otros han jugado a crispar al nacionalismo. Algo que les venía muy bien como botín electoral. Para que haya una reconciliación, que es lo que nosotros proponemos a la sociedad vasca, lo primero es dejar de utilizar la cuestión vasca como botín electoral... Nosotros aceptamos todas aquellas modificaciones de estatutos que se planteen dentro de la Constitución y que logren un consenso mayor al que se alcanzó la vez anterior... Lo que no aceptamos, desde luego, es el plan Ibarretxe... Somos una sociedad plural y tendremos que llegar a acuerdos entre todos. Desde ese punto de vista, el PP no tiene por qué quedarse fuera». Sólo otras dos cuestiones más destacaron en la entrevista: la insensatez e irresponsabilidad de Carod Rovira, que ya estaba pagada con su exclusión del gobierno catalán, y la crítica a Aznar - cadáver político del que no merecía la pena hablar- al que no se le reconocía

39 El Correo 5-3-04 (28).

40 El Correo 6-3-04 (26). 
ni el mérito de retirarse de la vida política, porque lo podía haber hecho antes, y, al que, sin embargo, se le acusó de irresponsabilidad absoluta por intentar desestabilizar al gobierno catalán, además de la contrarreforma educativa, el decretazo sobre el tema del trabajo, la pérdida de calidad de la democracia por el uso y abuso de la mayoría absoluta, la falta de trasparencia en la privatización de empresas públicas y el uso de los medios de comunicación ${ }^{41}$.

Rodríguez Zapatero, según la prensa, endureció su campaña contra Rajoy (en realidad siguió en la misma tónica anterior repitiendo temas y expresiones) a quien llamó incompetente en los diversos cargos ministeriales que desarrolló, obsesivo con Carod Rovira hasta el punto de no tener ninguna otra cosa de que hablar a los españoles, desmemoriado por no reconocer que el PP llegó al poder con los votos de Arzalluz y Puyol, mediocre lector de discursos, carente de autoridad moral y candidato a la oposición. La petición de voto iba dirigida a todos los ciudadanos para que apostasen por «el cambio para abrir una etapa social, limpia, noble, ilusionante, de concordia y que recupere los mejores valores de la España plural y diversa» frente al engaño y la manipulación permanente del PP en asuntos como la guerra de Irak, el Prestige o la huelga general. El gobierno del cambio sería «amable, tolerante y respetará a todo el mundo» ${ }^{2}$.

En términos semejantes se expresaron sus compañeros de partido de Euskadi. Pastor añadió que el PP se estaba convirtiendo en un peligro público y los demás oradores incluyeron en sus críticas al nacionalismo, cuyo votos pidieron para conseguir el único cambio posible dentro y fuera de Euskadi. Patxi López atisbaba en los sondeos el triunfo de Zapatero y Rojo apostaba por los nacionalistas dentro de la Constitución y por el triunfo de una España plural que estaba en riesgo ${ }^{43}$.

El discurso de Zapatero en San Sebastián fue una repetición de las acusaciones al PP, a las que añadió: «Somos la fuerza política que mejor puede asegurar la convivencia. Nunca hemos jugado a separatistas, como el PNV, ni a separadores, como han hecho los populares». Según Alfonso Guerra, el PP había vuelto a dividir a los españoles en dos bandos. Dado el bloqueo institucional entre el gobierno central y el vasco el cambio necesario en España era imprescindible para el País Vasco. La tesis era que el único capaz de asegurar la convivencia en Euskadi era el PSOE ${ }^{44}$.

${ }^{41}$ El Correo 6-3-04 (28 y 29).

42 El Correo 7-3-04 (30).

43 El Correo 7-3-04 (36).

${ }^{44}$ El Correo 8-3-04 (17). Ver, también, 9-3-04 (18 y 19), donde Zapatero dice a los jóvenes que el proyecto que su generación desarrolló con la Constitución está acabado y que a ellos correspondía su actualización. 
En rueda de prensa los socialistas convirtieron básicamente el día de la mujer en un ataque total contra el Partido Popular. La política del PP había «supuesto un verdadero frenazo, cuando no un paso atrás, en el avance de la igualdad de la mujer. Según José Antonio Pastor, los populares eran «corresponsables, por acción u omisión, de los cientos de mujeres asesinadas por sus maridos», además de ser culpables «de la discriminación laboral de la mujer y de no haber querido aprobar, hasta en tres ocasiones, una ley contra la violencia de género». Tras ocho años de gobierno popular, dijo Arantza Mendizábal, las diferencias entre hombres y mujeres eran más acusadas. «El modelo del PP tiene una base ideológica y hace a la mujer responsable de conciliar la vida laboral y familiar, haciéndole asumir los costes de maternidad». La política popular había dado una falsa imagen de preocupación por las mujeres con medidas insuficientes, superficiales y, especialmente, carentes de la suficiente dotación económica. Era intolerable que en un país democrático el número de mujeres asesinadas por sus maridos hubiese sido de 500. Pero el triunfo socialista permitiría que la primera ley a aprobar fuese la Ley Integral contra la violencia de género. Los socialistas pensaban crear un Observatorio nacional de la violencia de género, un permiso de paternidad compatible con el de maternidad, una ley de igualdad de trato a hombres y mujeres y una representación política que potenciase el papel de la mujer en política ${ }^{45}$.

Javier Rojo volvió a las andadas de calificar a Rajoy de «líder de cartón piedra», sin agallas, añadiendo que no quería debatir en los medios de comunicación, porque tenía algo que esconder ${ }^{46}$.

Frente a los gobiernos sólidos que defendía el PP, Zapatero destacaba su propósito de formar un gobierno dialogante que escuchara y aceptara las críticas sin caer en la arrogancia popular. El cambio era algo imparable dijo en Gijón; la victoria estaba al alcance de las manos. Para cambiar España necesitaba el voto obrero. De nuevo ridiculizó a Rajoy por leer el «papelín» que le ponían todos los días para atacar a sus contrincantes. «Pero para papel, el que va a hacer el 14 de marzo. Ese sí que va a ser un papelón. Tenga cuidado en no hacer el ridículo y venga conmigo a un debate».Y, a propósito de la mayoría absoluta popular, defendió que había servido para «llevarnos a una guerra ilegal, manipular en televisión, hacer que la vivienda sea inaccesible y abandonar la escuela pública y la seguridad» ${ }^{47}$.

El PSOE quería construir Euskadi de otra manera y, por supuesto, no pensaba colaborar en los proyectos políticos del PP por crear dos Españas o dos Euskadis. Javier Rojo añadió, refiriéndose a Mayor Oreja, que estuviera

\footnotetext{
45 El Correo 9-3-04 (24).

46 Ibidem.

${ }^{47}$ El Correo 10-3-04 (19).
} 
tranquilo en su «viaje de despedida a ninguna parte» y que dejara de transmitir a la sociedad el «rencor» que todos los partidos habían decidido dejar en la transición. «Queremos entendernos - añadió-, queremos volver con más fuerza para transformar España y olvidarnos de estos ocho años que tanto retroceso y tanto rencor han traído a esta comunidad». Huertas, por su lado, dijo que «lo que toca decidir ahora, es quién gobierna en España: si sigue la derecha de la confrontación y la mentira o gobierna el PSOE con Zapatero». Otras intervenciones destacaron esta misma idea: el compromiso de destruir las trincheras políticas que existían en Euskadi, tender los puentes necesarios entre los gobierno central y autonómico y encontrar un mínimo común denominador que uniese a los vascos para avanzar en la normalización política y el apoyo necesario a aquella reformas del Estatuto que los partidos vascos consensuasen desde el diálogo y la legalidad, sin presiones para liderar la pluralidad del país, evitar las divisiones y lograr la paz $^{48}$.

Los puntos centrales del discurso de Zapatero en Toledo fueron la petición del voto a los desencantados que no votaron al PSOE en las anteriores elecciones; la seguridad en el triunfo socialista a pesar de lo que pronosticaban las encuestas; la intención de no gobernar a menos que obtuviera más votos que Rajoy - «es un buen principio para gobernar España con fuerza suficiente y no condicionado por las fuerzas minoritarias»-, aunque advertía que, en el supuesto de victorias ajustadas, las dificultades de formar gobierno serían mayores para el PP por haber gobernado contra todos - estudiantes, manifestantes contra el Prestige o la guerra de Irak - y, además, por la mayor capacidad de diálogo y entendimiento del PSOE; el cambio tranquilo y un gobierno ni partidista ni sectario; la oferta de todos los espacios publicitarios socialistas a cambio de un debate con Rajoy; la necesidad del triunfo socialista para que hubiese un partido respetuoso con los demás partidos, ya que el PP recurría al terrorismo para atacar al partido socialista, y la promesa de que si ETA era derrotada, la victoria sería del pueblo español y no de un partido ${ }^{49}$.

En una entrevista, Rodríguez Zapatero abordó varias cuestiones de una forma más ordenada que en los mítines, pero en los mismos términos y con los mismos argumentos. La primera afectaba al País Vasco y al PNV. Su primer plan con respecto al País Vasco era el de «tener un diálogo con el Gobierno Vasco para sumar más esfuerzos en la lucha contra el terrorismo, para entrar en una etapa de distensión y para que Ibarretxe y el PNV reconsideren su plan. Euskadi no necesita ni plan Ibarretexe ni plan Mayor Oreja, sino un plan de todos para construir el futuro»; el posible adelanto de las

48 El Correo 10-3-04 (22).

49 El Correo 11-3-04 (19). 
elecciones por parte del PNV demostraría que «Ibarretxe ha fracasado en esta etapa de gobierno. Teniendo una mayoría en el Parlamento, como dice que tiene, sólo conseguiría llevar a la sociedad vasca a una nueva división al cincuenta por ciento. Euskadi no necesita elecciones, sino diálogo»; el plan Ibarretxe estaba «en la vía de descarrilar. Es imposible que prospere ante la oposición que mantenemos el PSOE y el PP. Los nacionalistas tienen que salir del ensimismamiento en que les ha metido un proyecto maximalista y de partido, que divide a la sociedad vasca; saben que el camino que han emprendido sólo va a contar con nuestra oposición democrática y dialogante, pero con oposición»; en cuanto a la acusación nacionalista contra el PSOE de hacer seguidismo del PP, Zapatero decía que «el PNV sustenta un discurso electoral basado en la indiferenciación entre el PP y el PSOE, que no se lo cree nadie. No hay más que verle a Rajoy y verme a mí. Es imposible que algún ciudadano piense que PP y PSOE se parecen»; el discurso de Imaz le parecía razonablemente esperanzador, mejor que las voces escuchadas anteriormente y creía que «los resultados del 14-M van a ser muy importantes para el giro de la estrategia del PNV. Si la sociedad vasca nos da un voto muy fuerte, como espero, el PNV e Ibarretxe sabrán que tienen que reconsiderar su estrategia. Si después del 14 de marzo hay un Gobierno del PSOE, el lehendakari sabrá que no le valdrá el argumento de que hay un Ejecutivo centralista, que niega lo vasco. Somos el PSOE del Estatuto, el que gobernó con el Gobierno Vasco, el PSOE del euskera, de la ikurriña, el que ha defendido siempre lo que es la identidad vasca dentro de un marco razonable, que es la Constitución»; los malos tratos recibidos por parte del PNV también los habían recibido del PP, «pero sabemos que es nuestro papel. Somos lo únicos que no concebimos con un carácter de exclusividad ni Euskadi ni España, los únicos que apostamos por una convivencia distendida». No había que confundir el diálogo con el acuerdo y el entendimiento. Con el plan Ibarretxe podía haber diálogo, pero nunca entendimiento y el acuerdo era imposible. La ley de Partidos y la ilegalización de Batasuna le parecieron positivas y, tras los últimos golpes policiales, veía a ETA muy débil.

La segunda cuestión se refería a las formaciones de gobierno. Zapatero no tenía entre sus objetivos recurrir al PNV para gobernar y, con respecto a CiU, se remitía a lo que ésta había declarado: que no apoyaría ni al PP ni al PSOE. Él, por su parte, ni les había invitado ni les había ofendido. Con respecto a IU y ERC, el candidato socialista eludió la pregunta, sugiriendo que las acusaciones de los populares en sentido de acuerdo con ellos, buscaba su descalificación. Reconoció el error de Carod Rovira por su reunión con ETA así como que ya lo había pagado, a diferencia de otros como los populares que no los reconocían (Yakolev 42, armas de destrucción masiva en Irak, Prestige). El tripartito catalán tenía futuro y disgustaba a la derecha, lo mismo del PP que nacionalista y «con mayor o menor grado de cinismo». 
La tercera cuestión era la organización territorial del Estado. Ello requería la reforma del Senado, la instauración de una conferencia de presidentes autonómicos y el refuerzo de todos los instrumentos de cooperación entre comunidades autónomas y entre éstas y el Estado. La reforma de los estatutos era posible, siempre que se hiciera respetando la reglas de juego, pero Zapatero no respondió si se inclinaba por la línea federalizante de Maragall o por la centralista de Bono; simplemente respondió que en el PSOE no había corrientes y que era el partido que mejor comprendía a España y que más se parecía a España; por otra parte, los gobiernos autonómicos estaban para defender sus intereses territoriales y le parecía normal que cada presidente autonómico defendiera sus tesis. El candidato socialista estaba seguro de que el PP llegaría a realizar un pacto de revisión estatutaria con el PSOE. Su planteamientos actuales eran pura estrategia electoral. A la pregunta de si no era una forma de contentar a todos la idea de crear 17 agencias tributarias y diecisiete tribunales superiores dejando sin competencias al Tribunal Supremo, Zapatero contestó: «Todo eso existe en la Constitución. Hasta 1992 no había Agencia Tributaria en España; la puso en marcha Borrel, y es una forma de organizar la Hacienda pública».

La cuarta cuestión era la del cambio tranquilo, que se veía en la ciudadanía y en los sondeos de opinión después de un gobierno del PP con manipulaciones, mentiras, descalificaciones, división, crispación y fracasos en resolver los problemas.

El quinto tema era el de la crítica al PP y a Rajoy. Nada más responder con que él juega muy limpio a la pregunta de si no criticaba al PP, calificó a Rajoy de incompetente en el Ministerio de Interior y en el tema del Prestige, de falto de sentido común por llamar hilillos de plastilina a la marea negra, de ridículo por leer los papeles que le ponían delante en los mítines (lo dijo tres veces en la entrevista y varias más en días anteriores), de no aceptar un cara a cara con él porque le temblaban las piernas y de tener un carácter indefinido. Y con respecto al resultado de las elecciones no aceptó la pregunta de que lo que se ventilaba era la mayoría absoluta o relativa del PP, estrategia de los poderosos, sino quién iba a ganar: ganaría la ciudadanía y perderían los poderosos. «Sé muy bien de qué hablo». La campaña no había estado mal diseñada y todos los sondeos habían mostrado un ascenso progresivo del PSOE.

Por último, estaba su partido. El crecimiento de los «enanos» dentro del PSOE, cuando las cosas parecían que le marchaban bien, lo interpretó como dificultades de la vida pública y como pruebas que sirven para forjarse y para constatar si hay madera. No contestó a la pregunta de si le cortarían la cabeza en el caso de perder las elecciones, porque las iba a ganar. Y sobre la posibilidad de que hubiese agazapados ante una debacle 
electoral, creía Zapatero que había más agazapados en el PP que en el $\mathrm{PSOE}^{50}$.

El último mensaje socialista en Euskadi antes del 11-M, dirigido a los votantes de Izquierda Unida y, en parte, también, a los nacionalistas, repetía que el cambio para los vascos sólo podía venir con el triunfo de Zapatero; de ahí la necesidad de concentrar el voto en las candidaturas socialistas y de que no se perdiese ningún voto progresista. Más repetición eran los ataques al Partido Popular. Pastor acusó a Aznar y a Rajoy de resucitar el fantasma de las dos Españas, mientras que Arantza Mendizábal denunció el abandono paulatino de la industria vizcaína, porque su modelo económico se basaba en el ladrillo y en la especulación; por otra parte, el triunfo del PP representaría el cierre de la sede central del BBVA en Bilbao. También Rojo arremetió contra el PP al acusarle de haber quebrado la convivencia en el País Vasco introduciendo dosis de rencor en la política vasca. El Partido Socialista, en cambio, apostaba por planes positivos para la convivencia. No faltó alguna crítica al nacionalismo; el mismo Rojo recordó a Ibarretxe que si bien hacía falta un plan para la igualdad entre el hombre y la mujer, también hacía falta otro plan para la igualdad entre nacionalistas y socialistas ${ }^{51}$.

En resumen, éstos fueron los argumentos utilizados por el Partido Socialista en la campaña. En primer lugar, la descalificación del adversario, que en este caso se redujo prácticamente al Partido Popular y sus personas: carroñeros, demagogos, desvergonzados, faltos de sentido común, ridículos, irresponsables, ambiciosos, inmorales, mentirosos, prepotentes, soberbios, incompetentes, desmemoriados, mediocres y arrogantes fueron algunos de los insultos repetidos a lo largo de toda la campaña, incluidos los días posteriores al 11-M. En segundo lugar, la denuncia de la política de gobierno y del bloque doctrinal del PP, que en algunos casos fue una auténtica falsificación de la realidad: imposición de la ideología popular como pensamiento único; utilización partidista de ETA, Constitución y terrorismo como instrumentos electorales; falta de homologación con la derecha europea; inmovilismo, manipulación de la Justicia y de los medios de comunicación; defensa y participación en la guerra injusta; ruptura de la convivencia en el País Vasco; terrorismo como único discurso electoral; estrategia antinacionalista para impedir que el PSOE llegara al poder; especulación inmobiliaria y abandono del desarrollo tecnológico; incomunicación institucional y confrontación permanente; responsable de la crisis política más grave de la historia vasca; culpable del antinacionalismo en España y del antiespañolismo entre los nacionalistas catalanes y vascos;

50 El Correo 11-3-04 (20 y 21).

51 El Correo 11-3-04 (24). 
brazo político del clero; corresponsable con el PNV de la crispación y de la gestión de la convivencia entre los vascos; empleo precario y temporal; abandono de la escuela pública y de la seguridad; máximo impulsor del nacionalismo vasco; amiguismo; corresponsable de las mujeres asesinadas por sus maridos y recreador de las dos Españas y de las dos Euskadis. En tercer lugar: la alternativa socialista: reformismo, cumplimiento del derecho internacional, diálogo institucional, programa social avanzado, reformas estatutarias, rechazo del plan Ibarretxe, moderador del nacionalismo, ni separatistas ni separadores, garantía de la convivencia y de la alternativa en Euskadi, reorganización territorial del Estado, defensa de la ilegalización de Batasuna y cambio tranquilo. Y, en cuarto lugar, confianza absoluta en el triunfo electoral.

\section{Campaña del PP}

El eje de la campaña popular fue el desafío nacionalista al Estado en su doble vertiente nacional y autonómica. A nivel nacional el desafío procedía de la debilidad del Partido Socialista y de sus alianzas y pactos con los nacionalistas; a nivel autonómico el reto al Estado procedía del nacionalismo vasco a través del plan de Ibarretxe. La derrota de este desafío sólo la podía garantizar el triunfo del Partido Popular por mayoría absoluta.

El programa y el proyecto político ocupó el $20,75 \%$ de la campaña, mientras que los partidos políticos se llevaron el 79,24\% de las intervenciones, repartidas más o menos a partes iguales entre el Partido Socialista y los nacionalismos, especialmente el nacionalismo vasco del PNV. A pesar de la intervención de distintos líderes populares, el núcleo central lo desarrollaron Rajoy, a nivel nacional y con alusiones al nacionalismo vasco, y Mayor Oreja, centrado de forma casi absorbente en el nacionalismo vasco y el plan Ibarretxe.

La respuesta al planteamiento nacionalista de las elecciones la dio Mayor Oreja al manifestar que la trascendencia de las mismas radicaba en que la única forma de hacer frente al plan Ibarretxe era la victoria del PP. Mientras otros, refiriéndose a los socialistas, habían comenzado la campaña manifestándose con Carod, los populares lo hacían con quienes defendían la Constitución y con quienes eran la mayoría de España. El plan Ibarretxe, según María San Gil, era el órdago separatista que se anteponía a la necesaria convivencia entre los vascos y a sus necesidades, mientras el PSOE pretendía gobernar en España sin gobernar en su propia casa, acabar con ETA a la vez que pactaba con ERC y suscribir un pacto de Estado contra el terrorismo que no respaldaban muchos de sus candidatos. Quienes reclamaban una revisión del modelo de Estado y una reforma de los 
Estatutos (Eugenio Azpiroz) no expresaban las preocupaciones reales de los ciudadanos. Ni siquiera en Euskadi era un clamor social. El cuestionamiento permanente del marco político hacía perder energías importantes y provocaba inestabilidad. El PP defendía el cierre estatutario. Por otra parte, las competencias estatutarias pendientes de transferencia a Euskadi eran más bien flecos que cuestiones importantes ${ }^{52}$.

De nuevo, Mayor Oreja declaró el objetivo popular de derrotar al nacionalismo con el triunfo de Rajoy en España y, también, en Euskadi, pidiendo para ello el voto de los vascos de izquierdas avergonzados del comportamiento de sus líderes. La victoria consumaría la derrota del terrorismo y resolvería definitivamente los problemas territoriales de España, atreviéndose a decir «no» a las minorías radicales nacionalistas, porque la alternativa no estaba entre la derecha o la izquierda, sino «entre una mayoría de españoles que quiere un Gobierno que les represente y un conjunto de minorías que desde el crimen o la mentira, y otras veces asociados, quieren imponer su razón de ser y estar en la política». ETA había aprovechado los balones de oxígeno que le dieron el PNV en Estella y ERC en Perpiñan y, convertida en aval de la ruptura de España, bendecía a quienes lo intentaban ${ }^{53}$.

La importancia de las elecciones radicaba en que servirían de termómetro para el nacionalismo en su pretensión final de independizar Euskadi de España. Ya nadie podía decir que el PNV aceptaba las normas que habían regido la vida de todos los vascos. Había que ganar, si no se quería llegar a un lugar irreversible. El adversario político en Euskadi (Alfonso Alonso) no eran los socialistas, sino el PNV con su «proyecto de ruptura con España, y de riesgo para los vascos» ${ }^{54}$.

A nivel nacional el discurso popular (Rajoy) se centró sobre el Partido Socialista y su candidato. Al primero acusaba de alejarse del Pacto por las Libertades y contra el Terrorismo, cuando a él se debían los éxitos contra el terrorismo de la anterior legislatura que permitían afirmar que el fin de ETA estaba más próximo. La traición e incoherencia del PS estaba en la carencia de un modelo económico y de un modelo de Estado. A Rodríguez Zapatero, «un extraño señor vestido de negro y con una especie de corbata algo así como de lunares», se le negaba capacidad para gobernar. Frente a

52 El Correo 27-2-04 (26)

53 El Correo 28-2-04 (28).

54 El Correo 29-2-04 (36). En esta misma página, Otegi, fuera de campaña por la ilegalización, no deja de repetir lo de siempre: después del 14 de marzo se abrirá una dinámica de diálogo; la izquierda abertzale tiene la mano tendida para ir a la raíz para resolver el conflicto político y traer la paz; la ilegalización no sacará a la izquierda abertzale del panorama político y que su voz, la de Herri Batasuna en Madrid, ha sido la única que, en lugar de halagar los oídos, fue a decir que «somos una nación y queremos la autodeterminación». 
un señor «triste, de alguien enfadado con todos, de alguien sin ilusión», yo - dijo Rajoy - «quiero una España alegre, feliz, segura de sí misma en la que la gente sabe que puede ir a mejor y lo mejor aún está por llegar. Ésa es la España en la que creemos y por la que vamos a trabajar» ${ }^{55}$.

Frente al «ensayo» que sería un gobierno socialista apoyado en una coalición de pequeños partidos, algunos nacionalistas, sin capacidad, desunida y sin ideas, Rajoy defendió el aval de la experiencia del PP. «En España no estamos para perder cuatro años, no estamos para perder el tiempo», y, en respuesta a los cuatro mandamientos de ZP, añadió: «Hoy la corrupción no está entre los primeros cuarenta problemas de España» a diferencia de la era socialista, cuando también decían que el problema del paro era un problema estructural ${ }^{56}$.

A pesar de las encuestas favorables al PP, Rajoy advertía de que nada estaba decidido y, parece que buscando el voto del centro, anunciaba invertir más en gasto social, porque ahora era el momento en que se podía. Los pilares de la estabilización económica estaban en las políticas de Aznar: déficit cero, creación de empleo y superávit de la Seguridad Social. «Aquí - dijo - todos somos exactamente igual de bienintencionados. No hay un solo español, vote a quien vote, que no quiera que se suban las pensiones, una sanidad mejor, una educación mejor. El problema es tener la inteligencia y la capacidad para hacer una política económica que te permita luego obtener buenos resultados» ${ }^{57}$. Las críticas a los partidos destacaron los riesgos para los españoles y para hacer lo que querían los españoles que causaban los nacionalistas y la poca seriedad de Zapatero, que carecía de modelo de Estado y que estaba dispuesto a entregar un ministerio a Llamazares. Hacía falta estabilidad y serenidad. «No es que vayamos a prohibir por decreto que haya señores cabreados, pero este país necesita sentido común ${ }^{58}$. El objetivo del PSOE - sin liderazgo y sin visión del futuro - era alcanzar el poder como fuese, bien pactando con IU o con ERC. Si el Pacto de las libertades gozaba de buena salud era gracias a los populares y a pesar de la debilidad del PSOE. Suya era la culpa de que ERC, con el 15\% de los votos de Cataluña, se hubiese hecho con el mando del PSOE ${ }^{59}$.

En cuanto al nacionalismo vasco, Astarloa afirmó que el plan Ibarretxe llevaría a todos los vascos «a la máxima de las miserias y a un futuro

55 El Correo 28-2-04 (24).

${ }^{56}$ El Correo 29-3-04 (31). La misma idea de corrupción socialista repite Aznar en su intervención en un mitin en Tomelloso; ver El Correo 2-3-04 (22).

57 El Correo 1-3-04 (18).

58 Ibídem

59 El Correo 1-3-04, (22). 
protagonizado por la crispación social». El PNV no podía acudir a Madrid a enfrentarse al «mundo mundial» con un proyecto excluyente. Los nacionalistas habían puesto encima de la mesa una propuesta, que preveía la ruptura de España ${ }^{60}$.

Rajoy continuó en Pamplona la crítica al PNV y al nacionalismo al afirmar que no era él quien tensionaba el debate electoral, sino Ibarretxe por tomar decisiones que no le correspondían como la de atribuirse el derecho de autodeterminación. El diálogo se hacía imposible por la presentación de un plan viciado desde su origen. Rajoy exigía al lehendakari lealtad al Estatuto para poder dialogar sobre su reforma. El debate tenía un límite, el de la España constitucional, que en opinión del candidato popular sólo defendía su partido, ya que el PSOE había traicionado sus tradicionales principios vendiéndose a ERC con el fin de obtener el gobierno de la Generalitat, idea en la que también insistió Aznar en otra intervención ${ }^{61}$.

En Bilbao, Iturgaiz felicitó a las Fuerzas de Seguridad por la detención de los etarras en Cuenca y criticó a quienes pactaban y dibujaban mapas terroristas con ETA y a los socialistas vascos por abandonar la representación de la alternativa al nacionalismo. Patxi López pretendía alejarse del PP y aislarlo para entregarse en manos del nacionalismo. El PP era el único capaz de hacer descarrilar el plan independentista y secesionista de Ibarretxe y de frenar las pretensiones de Imaz de lograr una fuerte representación en Madrid. El voto útil del constitucionalismo era el voto al PP. Astarloa, por su parte, defendió la sensibilidad de izquierda del PP con medidas de apoyo integral a la familia y a la conciliación entre la vida familiar y laboral ${ }^{62}$.

Los populares, que reconocían la posibilidad de perder la mayoría absoluta, volvieron a centrarse en la crítica a los socialistas. Los argumentos fueron los habituales: terrorismo, solidaridad y unidad de España. El primero lo utilizó Rajoy al responder a las dudas sobre la detención de los etarras, que había sugerido el socialista Rodríguez Ibarra y que se sumaba a la acusación anterior de Felipe González de hacer campaña con dos encapuchados. Harto de tales palabras Rajoy manifestó: «Esta es la vergüenza nacional; al final la Guardia Civil va a tener que acabar pidiendo perdón a dos sujetos que iban a colocar una bomba en Madrid y provocar una masacre de colosales consecuencias». El segundo lo utilizó también el candidato al destacar el miedo a la insolidaridad entre regiones que, en su opinión, propugnaba el primer partido de la oposición como consecuencia de sus pactos con Ezquerra Republicana de Catalunya. El tercer argumento

60 El Correo 1-3-04 (22).

${ }^{61}$ El Correo 2-3-04 (22).

62 El Correo 2-3-04 (26). 
lo utilizó Aznar al retar a Zapatero a que explicase cómo pensaba gobernar si al mismo tiempo tenía un pacto con los que querían cargarse a España. El PP era el único capaz de garantizar la Constitución y no quería que aventureros y personas insolventes se acercasen al gobierno de España ${ }^{63}$.

Mayor Oreja llamó al secretario general del PSE «Patxi López Arzalluz» por la repetición de los insultos y descalificaciones que le dirigía en su momento el ex presidente del PNV. El PP, no obstante los nuevos derroteros socialistas, seguía fiel a sus principios y valores y no desistía de su empeño de desalojar democráticamente al nacionalismo del poder. Su partido representaba la realidad frente a la ficción y la mentira del plan Ibarretxe. Las elecciones no enfrentaban a la derecha contra la izquierda, sino la estabilidad contra la inseguridad y los riesgos del proyecto nacionalista. Los hechos demostraban «la realidad del éxito de la democracia española, de la Constitución y de la Guardia Civil» (por las recientes detenciones) frente a la mentira nacionalista, que ni siquiera era capaz de garantizar las pensiones de los vascos, según el informe de la UPV encargado por el propio Gobierno Vasco. El PNV sólo buscaba mantenerse en el poder, pero había que movilizarse, porque no valía «con reírse de la ficción y decir que nunca llegará a ser una realidad. Hay que tener más votos» ${ }^{64}$.

Según la prensa, Rajoy cambió de táctica de campaña casi al final de la primera semana (afirmación poco rigurosa), pasando de la explicación de su programa al ataque directo al adversario, a Zapatero, a quien reprochó su nula personalidad, convicción y criterio al callarse, en su momento, ante la corrupción de los gobiernos de González y al no oponerse ahora a las dudas sembradas por algunos socialistas ante las últimas acciones policiales contra ETA. «Yo garantizo - dijo - un gobierno honesto, con la autoridad moral que me da que hoy esta cuestión no figura entre los primeros cuarenta problemas de España». Rajoy añadió un rotundo «no te creo», dirigido a Zapatero, por su afirmación de que no gobernaría, si no era el Partido Socialista el partido más votado, recordándole cómo los socialistas habían conseguido el gobierno catalán, el gobierno de Baleares y lo habían intentado en Madrid, argumento que también repetiría Aznar. El presidente del gobierno, para quien Zapatero era el líder más insolvente del PSOE que había conocido, utilizó el argumento de que algunos de los futuros aliados de los socialistas querían liquidar España y, en concreto, censuró a Carod Rovira por no pedir excusas por su reunión con ETA y por no felicitar a la Guardia Civil. El PP, por su parte, pensaba acabar con los etarras y hacerles cumplir íntegramente su penas ${ }^{65}$.

${ }^{63}$ El Correo 3-3-04 (19).

${ }_{64}$ El Correo 3-3-04 (22. y 37).

65 El Correo 4-3-04 (19). 
Fue Rato el que planteó en Portugalete que para los dos problemas más importantes de España, el final del terrorismo y el pleno empleo, la garantía estaba en el PP y no en un PSOE «peleado, dividido y enfrentado» y con «distintas visiones territoriales». Si el PP no sacara mayoría absoluta, el avance en tales tareas iría más despacio en Euskadi. Lo mismo ocurría frente al plan Ibarretxe, donde la oposición frontal del PP se distinguía de la duda que plantearía un PSOE aliado con los nacionalistas periféricos; Patxi López diría que no, pero creaba incertidumbre la postura de Maragall. Por otra parte, las promesas de Astarloa de multiplicar esfuerzos por desarrollar la vivienda y las infraestructuras en la margen izquierda se sumaron a la denuncia de Iturgaiz contra los socialistas por no poder contar con ellos en la defensa de la Constitución y del Estatuto, ya que se habían contagiado de los modos y maneras del PNV ${ }^{66}$.

El argumento de los riesgos para España de un triunfo del PSOE lo volvió a utilizar Aznar. Supondría un cambio de régimen. El PSOE había abandonado su carácter nacional para pactar el desmantelamiento del Estado con radicales y extremistas, en referencia a Carod Rovira ${ }^{67}$. En la misma línea se movió Rajoy: el paro, la corrupción y la desmembración de España aguardaban detrás de un posible triunfo socialista. «El PP - dijo Rajoy - necesita de una mayoría estable para que sigamos progresando, porque la alternativa es una alternativa sin programa, sin experiencia, que quiere darle la vuelta a todo y no tiene más objetivo que el de que no gobierne el PP; la coalición alternativa al gobierno del PP es un riesgo claro para España». El candidato popular se comprometió a modificar la financiación de los ayuntamientos para que no dependiesen del suelo en sus presupuestos y a crear un nuevo tipo de vivienda intermedia entre la libre y la protegida ${ }^{68}$. Iturgaiz llamó clones del PNV a los socialistas y Arenas calificó de gobierno de pancarta - dicho también por otros populares - al conjunto de opositores contra el $\mathrm{PP}^{69}$.

La segunda semana de campaña la empezó Rajoy con la exposición de su programa fiscal, con la defensa de que el PP ocupaba en exclusiva el centro político y con los mismos ataques a Zapatero, sólo que en esta ocasión estaban apoyados en nuevas noticias e intervenciones de Carod Rovira - la independencia de Cataluña ya ha comenzado o la Generalitat había tanteado que el Barça jugase la liga francesa - . «¿Después de esto - dijo Rajoy - va usted a romper la coalición con ERC, o va a tener el mismo gesto de autoridad que tuvo cuando el señor Carod se reunió con ETA?».

\footnotetext{
66 El Correo 4-3-04 (21).

${ }^{67}$ El Correo 5-3-04 (21)

68 El Correo 5-3-04 (22).

69 El Correo 5-3-04 (25).
} 
Insistiendo en lo mismo y buscando el voto socialista repitió: «Lo dicho por Carod Rovira no es de recibo y si usted (Zapatero) tuviera gallardía y respeto a la historia de su partido, a lo que piensan los votantes o una gran mayoría de los votantes de su partido, debería romper la coalición para no hacer el ridículo y no ponernos a todos en una situación que llega a ser imposible» ${ }^{70}$.

Michavilla se felicitó de que ETA no pudiese presentarse a las urnas a través de su organización política y de que «hoy quienes son perseguidos por la ley y el Estado de derecho, quienes huyen, son los amigos de los violentos. Quienes llevan tantos años dando la cara por la libertad la están consiguiendo». Añadió que el único sitio en el que los terroristas todavía tenían miembros de su organización, que vivían de nuestro sueldo, era el Parlamento Vasco y ello era así porque lo quería el PNV. «A mí - dijo - el PNV todavía no me ha explicado por qué a todas las leyes que hemos hecho para luchar contra ETA han votado que no y siguen amparando y protegiendo a un partido político que hoy está en la lista de organizaciones terroristas en toda la Unión Europea» ${ }^{71}$.

En su intervención en Bilbao, Rajoy expresó sus compromisos por erradicar el terrorismo y defender la Constitución frente a un plan de ruptura, el nacionalista, que no sólo sería derrotado, sino que llevaría al nacionalismo a la oposición. La Constitución era la única garantía de libertad y el oxígeno que necesitaban los vascos. Rajoy se adhería a cuanto significaba la palabra España y se comprometió a garantizar la presencia del Estado y de la ley en el País Vasco, el respeto escrupuloso a las instituciones y a los símbolos legales, la reafirmación del autogobierno vasco, la incentivación del bienestar frente a la economía de la secesión, la exploración de la posibilidad de desarrollar una mejor autonomía y no una mayor autonomía, la decencia y el diálogo político, concepto adulterado por el nacionalismo, porque «negociar para excluir no es dialogar; es excluir. Y sentarse alrededor de una mesa parra pactar proyectos políticos con los terroristas no es dialogar, es legitimar políticamente el terrorismo» ${ }^{72}$.

Aznar, por su parte, calificó a la alternativa al PP de coalición de pancarteros, zapateros y comunistas, que desayunaban todas las mañanas galletas de rencor o de odio, y de partidos que defendían romper España. El periódico en su encabezamiento calificaba esta y otras semejantes afirmaciones de exhibición de un nacionalismo español recalcitrante ${ }^{73}$.

70 El Correo 6-3-04 (22).

71 El Correo 6-3-04 (25).

72 El Correo 7-3-04 (28 y 29).

73 El Correo 7-3-04 (29). En la misma información se dice que Aznar utilizaba el término España una media de 12 veces por cada intervención en sus mítines. 
En una entrevista realizada a la mitad de la campaña, Mayor Oreja, cabeza de lista del PP en Álava, defendió que era importante que el PP sacara un gran resultado para así afrontar el desafío nacionalista de la siguiente legislatura. Era el PSE el que insultaba y trataba de obtener votos desde la diferencia y la división con respecto al PP y a la unidad anterior del constitucionalismo. Pero éste, que ni sabía ni podía ni debía insultar, tenía que estar representado por el PP. El cambio ocurrido en las relaciones entre el PSE y el PP se debía a que el secretario del PSE era nuevo, mientras que los responsables del PP eran los mismos. Correspondía a los socialistas explicar por qué defenestraron a Redondo y modificaron el esquema del PSE, ganando en su partido la tesis del «todos contra el PP» y su «maragallización». Mayor consideraba parte del anecdotario de una campaña llamar «Arzalluz» a Patxi López y, por el contrario, reconocía la rabia y la irritación que daba que le llamaran inmoral y carroñero, aunque lo asumía encantado. Ahora se le decía desde las filas del PSE lo que antes venía desde el PNV. Era el coste de la política de principios y convicciones del PP, cuya recompensa era mantener viva la esperanza y demostrar que era la política adecuada que había llevado a ETA a uno de los momentos de mayor debilidad de su historia. El PP se había atrevido a decir lo que era ETA, a apoyar las medidas de ilegalización de su brazo político y a fortalecer la Justicia.

De la posible desaparición de la alternativa (se ha de entender que al nacionalismo en el País Vasco) no había que hablar hasta después de celebradas las elecciones, pero éstas no estaban planteadas entre PP y PSOE, sino entre una mayoría que quería gobernar España y una suma de minorías que quería lo mismo y se aprovechaba de la debilidad socialista para que el PP no obtuviera la mayoría absoluta. «Aquí no va a ganar Zapatero, va a ganar el PP con una mayoría u otra. Eso es lo único que está en juego».

Las elecciones generales no eran una primera vuelta de las autonómicas, pero existía la posibilidad - de lograr una mayoría en España - de hacer descarrilar o, al menos, provocar la crisis del plan Ibarretxe.

La inclusión en el mismo saco a PNV, ERC y ETA era una fotografía de la realidad, era atreverse a decir la verdad. «Y la verdad es que ETA en Estella apoyó al PNV en su nueva estrategia y a Carod le ha ayudado en la suya en Perpiñan. Por eso, el eje de esta nueva ofensiva del nacionalismo está protagonizado por ETA. El nacionalismo tenía su vanguardia en ETA y lo que se está produciendo ahora es una sustitución de la banda por el grueso de los distintos nacionalismos. No es un invento, es una realidad que se verá en la próxima legislatura».

Mayor negaba que el PP fuera responsable de la subida esperada de votos de ERC. El ya había pronosticado que los de ERC serían los herederos de Pujol. Éstas y otras afirmaciones eran, según él, consecuencia de la búsqueda de la verdad, no de los votos. Hasta el momento todos su pronósticos 
se habían cumplido; ahora tocaba que se cumpliera la segunda transición que intentaban los nacionalistas, de modo que el problema de España después de las elecciones iba a ser el de la legislatura del desafío nacionalista.

La prioridad del PP estaba, de momento, en ganar las elecciones y, en lo que a él personalmente se refería, seguiría en el PP del País Vasco construyendo la alternativa al nacionalismo para desalojar democráticamente al nacionalismo del poder. Las expectativas de voto en las elecciones en el País Vasco estaban entre repetir los resultados anteriores y ganarlas, si es que contaban con el apoyo de todos los constitucionalistas que querían el cambio.

La razón por la que se estaba hablando muy poco del Plan Ibarretxe (esto era una equivocada apreciación) estaba en que las elecciones generales no eran las adecuadas; lo serían las autonómicas. Ahora los nacionalistas trataban de anestesiar al votante del PP para que éste no consiguiera mayoría absoluta y hubiese, a la hora del Plan Ibarretxe, un gobierno más débil en Madrid. El futuro del nacionalismo pasaba por un esfuerzo de reagrupamiento de ETA y el PNV. Y si bien ETA no era exigente con ERC, al PNV le exigía una negociación para el reparto de poder político.

Era cierto que el PSOE estaba contra ETA, pero no se había atrevido a romper con ERC y había permitido que uno de los ejes de la ruptura en esta legislatura siguiera en el gobierno de Cataluña, de manera que el PSOE estaba neutralizado por los acuerdos con Carod.

En cuanto al Pacto antiterrorista, Mayor opinaba que había sido un excelente instrumento, porque se hizo desde la exigencia y no desde la cantidad, y no tenía sentido abrirlo a otros partidos para que devaluasen su contenido ${ }^{74}$.

La intervención de Rajoy en Las Palmas recurrió, de nuevo, al discurso de la descalificación de los socialistas por su España de paro, de despilfarro y de corrupción y por sus relaciones con el independentismo catalán de Carod Rovira, que definían al líder socialista como un dirigente político débil, sin garras y sin agallas. Rajoy insistió en defender una política de inmigración sensata, que rechazara «los papeles» para todos y que apoyara iguales derechos, las mismas obligaciones y los mismos deberes para los inmigrantes que para los españoles. La petición del voto para obtener la mayoría la encubrió con la crítica a la incapacidad de Zapatero para crear un Ejecutivo sólido: «Sabéis por qué los demás no piden una mayoría y no quieren un gobierno estable, pues porque no pueden. Tampoco el PSOE, por eso lo que quieren es formar una coalición que es exactamente lo contrario de lo que le conviene a España. Ellos van a defender sus propios intereses y al final el PSOE va a tragar» ${ }^{75}$.

${ }^{74}$ El Correo 7-3-04 (34 y 35).

75 El Correo 8-3-04 (18). 
Mayor Oreja dio, una vez más, la versión vasca de la campaña, centrándose en la tesis de que la victoria por mayoría absoluta del PP — «no tener miedo a una mayoría clara, tranquila y firme en España» - era la manera de afrontar el desafío nacionalista vasco y garantizar a los españoles el futuro y la esperanza. El nacionalismo debía dejar de ser «una seña de identidad en el paisaje vasco», «como un monte que siempre está ahí». Su deseo era que los vascos viesen perder unas elecciones al PNV. El PP no trataba de integrar a los nacionalistas, sino de ser su alternativa y, por otra parte, no intentaba meter en la cárcel a Ibarretxe, sino de sacarlo de Ajuria Enea con los votos. A diferencia del PNV, que había abrazado el proyecto de ruptura de ETA, el PP se comprometía a acabar con ella de manera definitiva e inaplazable. Carmelo Barrio, por su parte, reprochó al Departamento de Interior su permisividad con la izquierda abertzale, permitiendo manifestarse en San Sebastián y seguir adelante con su campaña a favor del voto nulo, todo ello incumpliendo las resoluciones judiciales y los criterios de la Junta Electoral ${ }^{76}$.

El PP prometió por boca de Rajoy medidas de discriminación positiva para las mujeres en un acto celebrado sólo con mujeres. En otro acto del mismo día, en Valencia, destacó los asuntos que esperaban al futuro jefe de gobierno: pleno empleo, un buen puesto en la ampliada UE y la amenaza que supone para la Constitución los nacionalismos radicales. Él no tenía miedo a ningún desafío, contando con un gobierno sólido y con el respaldo de los españoles. «Vamos a ganar las elecciones - dijo - porque la mayoría de los españoles no quiere despilfarrar el capital de estos ocho años y porque no quieren malgastar posibilidades de futuro. Si queréis eso, que lo queráis de verdad, que me votéis el día 14 y me deis los medios para gobernar en España», porque, en el caso contrario, los socialistas estarían atados de pies y manos por sus socios, por sus acreedores. «Yo no conozco más acreedores que el conjunto de los ciudadanos españoles. Ningún partido, ninguna empresa, ni nadie. Esa es la independencia que me va a permitir defender el interés de España que es para lo que estoy». Y, con ocasión del Día de la Mujer, prometió para las mujeres un millón de puestos de trabajo de los dos que iban los populares a crear en la siguiente legislatura y, refiriéndose al candidato socialista, dijo: «Hoy hay quien ha dicho que si gana hará un gobierno paritario entre hombres y mujeres. ¿Y si la competencia, la inteligencia y la capacidad exige que sean todas mujeres? ¿Les quitará los puestos?» ${ }^{77}$.

La intervención de Mayor Oreja en Ermua, al día siguiente de que Rodríguez Zapatero dijera que los socialistas estaban contra el plan Ibarretxe

${ }^{76}$ El Correo 8-3-04 (20). Batasuna tuvo un acto a favor de la autodeterminación y del voto nulo (El Correo 8-3-04, p. 22).

77 El Correo 9-3-04 (19). 
y contra el plan de Mayor Oreja, se centró en el Partido Socialista y en el nacionalismo, como fue habitual durante la campaña. Al primero le respondió que el plan que había era que el día 14 ganase la Constitución. La importancia de «atreverse a decir la verdad», que había aprendido, precisamente, en Ermua, y el «espíritu de Ermua», que arrancó de la rebelión democrática de las víctimas contra el terrorismo, consistían en el momento en que hablaba en lograr la derrota definitiva del crimen, la mentira y el miedo en el País Vasco. Sólo el PP podía acometer semejante tarea, ya que el PSE la había abandonado para situarse en la equidistancia, la comodidad y la cobardía. Los socialistas echaban la culpa de todo al PP y mostraban una notable tibieza ante el plan de Ibarretxe. El camino del PSE era el mismo que anteriormente había seguido el PNV, situándose entre ETA y el Estado de derecho hasta acabar de abogado defensor de la banda terrorista. Por un camino similar, el PSE acabaría defendiendo «a quienes quieren romper» España. «No a quienes quieren matar, pero sí a quienes quieren romper». Con respecto a los nacionalistas vascos, les acusó de ser lo contrario del «espíritu de Ermua». Instalados en la ficción del plan de Ibarretxe, en «sus pensiones de filfa» y en la mentira a la que recurrían para neutralizar la verdad de Ermua, los nacionalistas ocultaban, de momento, sus planes para anestesiar a la sociedad vasca y seguir, después de las elecciones, su hoja de ruta con el reagrupamiento de los que asesinaron a Miguel Ángel Blanco y la negociación política con $\mathrm{ETA}^{78}$.

Los socialistas, según Rajoy, eran antipatriotas por promover un cambio que sería catastrófico para España. Ninguna de sus promesas era creíble, ya que en su historia negra estaba el paro, la corrupción y el déficit de la Seguridad Social. Hablando en Zaragoza, defendió el Plan Hidrológico Nacional con una condición innegociable, la de que el trasvase del Ebro no perjudicara a Aragón. «Sólo habrá trasvase si sobra agua. Es la pura verdad, lo demás no es cierto». La defensa, por otra parte, que Aznar hizo en Madrid de gobiernos sólidos, estables y reformistas - buscando con ello la mayoría absoluta de su partido - la fundamentó en el intenso y fecundo diálogo social que eran capaces de desarrollar tales gobiernos, cosa que no podría hacer un gobierno socialista atado por otros partido políticos. Así lo había sido su partido en la legislatura anterior, creando dos millones de puestos de trabajo, bajando el IRPF, renovando el Pacto de Toledo, luchando contra la siniestralidad laboral o eliminado el Impuesto de Actividades Económicas ${ }^{79}$.

Mayor Oreja pidió que se votase por la realidad del PP y no por la ficción del nacionalismo. El cambio nacionalista de los últimos años ha-

78 El Correo 9-3-04 (22).

79 El Correo 10-3-04 (18). 
bía consistido en pasar del monólogo del terror de ETA a una película de ficción, cuyos derechos estaban en manos de la organización terrorista con guión de Ibarretxe y Carod Robira con los actores principales del Gobierno vasco y catalán y otros actores secundarios. Para Mayor, España «no es una película, no es una transición en movimiento permanente, no es un mito. Queremos ganar para que con las siglas del PP gane la Constitución y la idea de que España es nuestra referencia para todos». Pero había que ganar con mayoría absoluta para que no pudieran realizarse coaliciones como la del gobierno de Cataluña. Los socialistas vascos no se atrevían a decir la verdad sobre los problemas vascos en los próximos años y, en repuesta a Montalbán que había acusado al PP de la crispación de la sociedad vasca, afirmó que en el País Vasco, después de ocho años de gobierno popular, no había kale borroka, los concejales de ETA estaban expulsados por ley de los ayuntamientos y tenemos el mayor número de ocupados de la democracia española. «Si esto es crispación, quiero que la sociedad vasca siga crispada porque significa que estamos en la buena dirección» ${ }^{80}$.

El problema no era tanto elegir entre Rajoy y Zapatero, sino asegurar una política de «firmeza democrática contra ese ataque nacionalista que en el País Vasco viene dado por el plan Ibarrretxe... secesionista, independentista, y que nos quiere llevar a la miseria y sacar de España y de Europa». Así se expresó Carlos Iturgaiz, quien insistió en decir que la ofensiva nacionalista era la ecuación de PNV, más ERC, más ETA, igual a independencia. El PNV, por otra parte, se había «echado al monte» ${ }^{81}$.

«Quiero hacer un poco más y un poco mejor de lo que ha hecho Aznar a lo largo de esos años», dijo Rajoy. Insistió, además, en que «lo que aquí está en duda es si España va a tener un Gobierno estable, que es lo que yo quiero y pido, o un Gobierno formado por partidillos que sólo se preocupan de sus intereses». El PP pensaba gobernar solo y, a partir de ahí, ya vería el partido. Incluso con mayoría absoluta, podría establecer acuerdos con otras fuerzas políticas, pero descartaba a CiU para formar gobierno. En defensa del modelo constitucional y de la España autonómica dijo en Barcelona: «Tened la absoluta seguridad de que son cientos y cientos los catalanes que piensan como vosotros. Sobran miles de histriones en la política catalana... Me preocupa y mucho, que los socialistas de Cataluña me critiquen por defender la España constitucional, la que siempre defendió el PSOE; y me preocupa más porque no critica a sus socios de Gobierno, que defienden un modelo de España que nada tiene que ver con lo que siempre ha defendido el programa socialista. Y me preocupa mucho más aún que firmen un pacto de gobierno en el que se condena y se prohíbe el diálogo con el PP y estén

80 El Correo 10-3-04 (21).

81 El Correo 10-3-04 (21). 
en el Gobierno con un partido que pacta con ETA». Por su parte, Rajoy pensaba contribuir a que Cataluña recuperase su moderación, equilibrio y sensatez, señas y principios que no estaban reñidos con el sentimiento de patria grande y chica: «Yo, como vosotros, creo en el sentimiento de identidad múltiple; me puedo sentir gallego y español y dormir tan tranquilo» ${ }^{82}$.

El triunfo claro y rotundo seguía siendo el tema del final de campaña popular. Según Astarloa era necesario para decir «no» con claridad a los planes de ruptura e imposición y «sí» a los valores clásicos como la libertad, el pluralismo, la igualdad, la fraternidad y la paz, y a los valores modernos de la eficacia, progreso y bienestar. La sociedad vasca debía rechazar el camino de la ruptura o de la imposición abertzale y optar por el diálogo y la construcción del futuro entre todos juntos. Repitiendo a Rajoy, afirmó que el PP no defendía más autogobierno, sino mejor autogobierno. «Hemos aprendido que no hay libertad sin pluralismo, que todo el mundo tiene derecho a defender sus ideas sin que ninguno se imponga a los demás y que el camino hacia el futuro se construye haciendo unidad de la diversidad». El objetivo del PP en el País Vasco, concluyó Astarloa en su intervención en Gernika, era el de «construir comunidad, primando lo que nos une sobre lo que nos separa». Nada nuevo en los ataques a los socialistas — «protagonistas del insulto» que engordaban el «zurrón» de ERC - , por parte de otros protagonistas del PP. Sólo cabe destacar la intervención de Jon Juaristi en San Sebastián en la que señaló que las elecciones planteaban la disyuntiva de consolidar la Constitución o «la confusión y el retroceso en las libertades». El PSOE había caído en la torpeza, añadió, de pensar que se puede «cabalgar el tigre de los nacionalismos» ${ }^{83}$.

En resumen, los argumentos se desarrollaron conforme a una estructura de tres cuerpos. En primer lugar, las descalificaciones: histriones, pancarteros, zapateros, comunistas, insolventes, corruptos, débiles, despilfarradores y protagonistas del insulto entre otros muchos. En segundo lugar, la denuncia y crítica a los partidos; por lo que respecta al Partido Socialista la denuncia, que llegó en ocasiones a la falsificación de los hechos y de las expectativas, incluyó sus alianzas y servidumbres con partidos pequeños y nacionalistas; la innecesaria revisión del modelo de Estado y la reforma de los Estatutos; el alejamiento del Pacto por las libertades contra el terrorismo; el riesgo de cambio de régimen, paro, corrupción y desmembración de España; la ruptura de la solidaridad entre españoles; ruptura de la unidad constitucional con el PP; la torpeza de pretender dominar los nacionalismos; el abandono de la alternativa al nacionalismo vasco; la imitación y repetición de los mensajes anteriores del PNV contra el PP; su neutraliza-

82 El Correo 11-3-04 (18).

83 El Correo 11-3-04 (23). 
ción por los acuerdos con ERC en Cataluña y la defensa de quienes querían romper España; con respecto al nacionalismo, denunció el apoyo de ETA al PNV y a ERC; la adulteración del concepto de diálogo por el PNV y su protección a Batasuna; el trabajo del PNV como abogado defensor de la banda terrorista; la sustitución de ETA por el conjunto de nacionalismos; el reagrupamiento de ETA y el PNV como base del futuro nacionalismo vasco; la aceptación del PNV del proyecto de ruptura de ETA; la negociación política con ETA; la pretensión de quitar votos al PP en favor de un gobierno socialista débil y poder dar el órdago nacionalista en la próxima legislatura. En tercero y último lugar, el PP defendió la necesidad de su victoria por mayoría absoluta con los siguientes argumentos: única forma de hacer frente al plan de Ibarretxe, al desafío nacionalista y de derrotar definitivamente al terrorismo; defensa de la Constitución y de la presencia de la ley y del Estado en el País Vasco; mejor autonomía, no mayor autonomía vasca; única fuerza capaz de decir no a las minorías nacionalistas radicales y de evitar los riesgos de ruptura de España; lealtad al Estatuto de Gernika como condición del diálogo político; desalojo democrático del nacionalismo del poder; aval para la creación del pleno empleo, discriminación positiva de la mujer y Plan Hidrológico Nacional; firmeza democrática contra el nacionalismo; condición del diálogo social y consolidación de la Constitución como alternativa a la confusión y al retroceso de las libertades ${ }^{84}$.

${ }^{84}$ Un resumen de las campañas de los dos partidos nacionales y del PNV apareció en el debate a tres bandas en el que participaron Mayor Oreja (PP), Ramón Jáuregui (PSOE) y Emilio Olabarria (PNV). Los tres participantes se mostraron de acuerdo en asuntos de interés social y económico - soterramiento del tren en Vitoria, urgencia de la «Y» vasca, finalización del puerto de Bilbao, mejora del puerto de Pasaia, intermodal de San Sebastián, mayor apoyo a las empresas e industrias, impulso a la sociedad de bienestar-, pero discreparon profundamente en los temas políticos. Esta es una prueba más de que la campaña fue una pugna política, en la que las alusiones sociales se usaron para agredir a los demás partidos más que como parte esencial de un discurso y de un programa. Los temas políticos fueron: 1 . El marco político. El PP: a favor de la Constitución y el Estatuto por la estabilidad y la garantía de libertad que proporcionaban; había que perseverar en ello para hacer frente en la siguiente legislatura al desafío nacionalista. El PSOE: más Estatuto y más diálogo entre demócratas; bloqueo absoluto en la política vasca desde que el PSOE perdió en 1996; «el país camina hacia las trincheras, hacia una derrota colosal». PNV: defensa del plan Ibarretxe aunque haya sido demonizado; trabajo conjunto en Madrid de los firmantes del pacto de Barcelona para construir un Estado plurinacional. 2. Plan Ibarretxe. PP: no a la segunda transición y a la reforma constitucional que formula el plan Ibarretxe; hay un desafío que viene del País Vasco y de Cataluña; «Carod, bendecido por ETA, está haciendo el juego a los que quieren destrozar España». PSOE: no es constructivo, es destructivo, divide a los vascos y no tiene encaje ni en la Constitución ni en Europa; sólo seduce a la izquierda abertzale. PNV: los pactos de Estado y las reformas legales han sido acordadas por el PP y PSOE y han supuesto un quebranto brutal de las libertades públicas, que no persiguen acabar con ETA, sino con el nacionalismo. Por ello, «el desafío de esta legislatura será regenerar el deterioro democrático». 3. Lucha contra ETA. PSOE: Avances en la lucha contra ETA; la Ley de Partidos y otras actuaciones han te- 


\section{La tragedia del día 11 en Madrid: La aparente suspensión de la campaña}

El día 11 se produjo en Madrid un atentado terrorista con la explosión de diez bombas en varios trenes de cercanías, que provocó una masacre de casi doscientos muertos y cerca de 1.500 heridos, algunos de ellos en estado crítico. El Correo ya recogía en la edición del día 12 que Al-Qaida había reivindicado la matanza, que, en un principio, el Gobierno atribuyó a ETA y, posteriormente, mantuvo como hipótesis prioritaria de investigación. La campaña electoral se suspendió, pero las iniciales coincidencias de los políticos que parecían anunciar un final de campaña basado en la unidad, se rompieron en cuestión de horas, dadas las discrepancias que surgieron. La campaña continuó de otra manera y retomó las tesis defendidas por los distintos partidos políticos durante los días anteriores al atentado. No hubo, por tanto, suspensión de la campaña, sino aparente suspensión.

Las manifestaciones que recogió el periódico del día 12 sobre lo ocurrido fueron numerosas ${ }^{85}$. Por lo que respecta a declaraciones, notas de insti-

nido efectos positivos. La política popular ha sido torpe con los nacionalistas y ha estimulado el nacionalismo radical en el País Vasco y Cataluña. El choque de nacionalismos se combatía con más autonomismo y era necesario impulsar un discurso de asimilación de los nacionalismo moderados. PP: era macabro (contra PNV) estar escoltado desde hacía veinticinco años por no compartir determinadas ideas y hablar de quebranto de libertades, cuando el PNV no ha sido capaz de garantizar las libertades individuales de los vascos. El PP (contra el PSOE) no ha creado más nacionalistas en Euskadi o Cataluña. «Son los mismos. Lo que ocurre es que el nacionalismo radical sustituye a veces al moderado». PNV: delegar en el Partido Nacionalista la responsabilidad de la falta de libertad de los militantes y cargos del PP y del PSOE era un discurso artificial y una inmoralidad. Sería difícil encontrar en el mundo un gobierno como el vasco que demostrara tanta preocupación y sensibilidad hacia las víctimas. 4. Las prioridades. PSOE: unidad de los partidos democráticos contra el terrorismo, «algo que no desea el PP, por lo que percibo», retomar el diálogo entre las instituciones, mejorar la colaboración policial y abrir el consenso de la lucha contra ETA, Pacto Antiterrorista, a otras formaciones políticas. PP: Mantener la exigencia de no pactar con ETA y sus cómplices ni con los que tienen contactos con ellos v.g. Carod Rovira. PNV: seguir con su política constructiva en Madrid; Imaz se debía a la ponencia política aprobada por el partido, elaborada por Arzalluz y Egibar. 5. Después del día 14. PSOE: tratar de llegar a acuerdos y a un entendimiento con el PNV, en el que había distintas posiciones políticas. El PP trataba al PNV como si fuera ETA y le acusó de haber manipulado y maltratado al PSOE tras los últimos acontecimientos. PP: Ibarretxe pondrá en marcha su plan, comparable con el acuerdo de Lizarra, para dar el salto de la autonomía a la autodeterminación, contando con el apoyo de ETA. «Es algo que no depende del PP, del PSOE o de talantes. Así pasará, hagamos lo que hagamos». PNV: Criminalizar al nacionalismo es una intolerable imputación. «Es un delirio pensar que la sociedad se divide en dos bloques, el del PP y el de ETA. Con estos argumentos será inviable buscar una solución a cualquier problema» (El Correo 6-3-04 (20 y 21)).

${ }^{85}$ Distingo entre declaraciones hechas inmediatamente después de los hechos, notas de instituciones, intervenciones de los políticos, breves comentarios y artículos de prensa, fijándome especialmente en las cuestiones de responsabilidad de los hechos y su valoración política. Los comentarios y artículos se tratan en la sección de «colaboraciones». 
tuciones y manifestaciones de políticos, todas, menos dos que consideraron probable la autoría de alguna organización terrorista islámica, expresa o tácitamente atribuyeron la responsabilidad a ETA. Algunos destacaron la indiferencia sobre la paternidad del atentado ante el daño causado y el problema planteado. Si bien en un principio no se vio o no se quiso ver la posible relación entre el atentado y los resultados electorales, a medida que pasó el tiempo surgieron las voces que defendieron la relación entre los resultados electorales y los atentados y, evidentemente, entre los resultados electorales y los autores de los atentados. Alguno vio la responsabilidad de Al-Qaida como consecuencia de la guerra de Irak y otros interpretaron la atribución a ETA o bien como agresión a la izquierda abertzale y al pueblo vasco o bien como una manera de evitar consecuencias negativas el día de las elecciones. Frente a lo manifestado por los miembros del Partido Popular, lo más frecuente por parte de la oposición fue manifestar preocupación y, fundamentalmente, formular acusaciones directamente contra el gobierno sobre la veracidad u ocultación de la información por motivos estrictamente electorales. El PP se reafirmó en su estrategia electoral de enfrentamiento radical contra el terrorismo de ETA y contra la maldad de los nacionalismos, mientras el PSOE siguió con la acusación de mentira de los populares aplicada ahora a la gestión de la información. El nacionalismo siguió atrapado entre los dos grandes partidos, negando todo aquello que le pudiese perjudicar por motivo del terrorismo (la vasquidad y el nacionalismo de ETA) y negando, también, cuanto le perjudicara ante la clientela nacionalista por acercamiento excesivo a los grandes partidos (defensa de la Constitución). Los políticos nacionalistas vascos acusaron a los demás de utilizar el terrorismo para atacar al nacionalismo, las ideas y los pueblos.

Las notas institucionales de los equipos vascos de fútbol contenían las condenas de rigor sin ninguna alusión a las cuestiones de autoría y valoración política.

El comité ejecutivo de la Conferencia Episcopal Española en una nota expresó su cercanía con las víctimas y defendió que ETA «es una organización intrínsicamente perversa, cuyas raíces se hallan en un tipo de nacionalismo totalitario e idolátrico... ETA considera un valor absoluto la independencia política del País Vasco y, para conseguir este fin, no ha cesado de menospreciar y pisotear las bases mismas sobre las que se sustentan el bien común y la paz, es decir, el respeto a los derechos humanos y, ante todo, el derecho a la vida... Nunca puede existir razón moral alguna para el terrorismo y no debe haber duda ni vacilación a este respecto».

También los obispados de Bilbao y San Sebastián en sendas notas reprobaron la monstruosidad de ETA y expresaron su «inmensa consternación».

Elkarri pidió una reflexión sobre la política antiterrorista seguida hasta el momento, porque el «unilateralismo no puede ser el camino», lo que a 
falta de mayores explicaciones era una crítica a la política de los grandes partidos.

Las cadenas de televisión cortaron sus emisiones para informar del atentado, salvo ETB que se justificó diciendo: «Queríamos hacerlo de inmediato, pero no fue posible porque somos una televisión pobre».

La declaración institucional de José María Aznar no afirmó expresamente que la autoría era de ETA, pero estaba implícitamente contenida en sus palabras: «... No vamos a cambiar de régimen ni porque los terroristas maten ni para que dejen de matar. Por eso les digo a todos los españoles que no debemos aspirar a nada que no sea la completa derrota del terrorismo, la derrota completa y total, su rendición sin condiciones de ninguna clase. No hay negociación posible ni deseable con estos asesinos que tantas veces han sembrado la muerte por toda la geografía de España... Somos una gran nación, somos una gran nación cuya soberanía reside en todos los españoles. Quien decide es el pueblo español. Nunca permitiremos, no vamos a permitir nunca, que una minoría de fanáticos nos imponga nuestras decisiones sobre nuestro futuro nacional».

Rajoy declaró que no había más camino frente al terror que el de la firmeza del Estado de Derecho y el de la solidaridad plena con las víctimas y sus familias. Ni con atajos ni con precios políticos se podía derrotar al terrorismo. Había que ir a por los terroristas sin tratos ni treguas, con la ley en la mano, sabiendo que eran el mayor enemigo que tenía España. Los ciudadanos esperaban de su gobierno firmeza y determinación, como esperaban de todos los partidos políticos coherencia y claridad. Rajoy - que no dio ninguna credibilidad a las manifestaciones de Otegi que negaban la autoría de ETA y señalaban a comandos islamistas - fue interrogado sobre las consecuencias de la masacre en la jornada electoral del siguiente domingo y contestó que «tratar de analizar lo que ha sucedido en clave electoral no es sólo una frivolidad, sino que también es hacerle el juego a los asesinos».

Cerca de la una del mediodía según crónica de Luis Sala, Zapatero manifestó que «estamos ante el atentado más horrendo que haya cometido nunca ETA. Ante una barbarie incalificable, cometida por un grupo de asesinos que quiere imponer su voluntad a una sociedad libre, a base de bombas. Es un acto que repugna a cualquier conciencia». Según opinión del candidato socialista, la respuesta inmediata al atentado debía incluir la suspensión de la campaña y la convocatoria conjunta de manifestaciones populares de rechazo al terrorismo y de reafirmación democrática.

No sólo la declaración de Zapatero atribuía el atentado a ETA, sino que Luis Sala afirmaba que, a última hora de la tarde y a pesar de que el ministro de Interior había informado de la nueva vía de investigación que apuntaba al terrorismo islámico, «el PSOE mantuvo en todos sus términos la declaración de su líder». 
También Llamazares atribuyó el atentado a ETA, a la que calificó de «organización nazi que tortura y asesina al pueblo». «Condenamos sin paliativos este atentado, a esta organización terrorista y cualquier objetivo político de esta organización...Vamos a estar en las movilizaciones convocadas para mañana por el Gobierno, como un solo pueblo, frente al terror, el nazismo, por la democracia y por la libertad».

La popular María San Gil no dudó de la autoría de ETA y criticó la «miseria y la mezquindad de algunos partidos» en alusión a EA.

«iQué monstruosidad!», dijo el Lehendakari Ibarretxe. Convencido de que ETA había realizado la masacre, añadió: «Realmente cuando ETA atenta, cada vez que ETA ha atentado y atenta se rompen (sic) en mil pedazos el corazón de los vascos y vascas, porque el pueblo vasco ha sido y será un pueblo civilizado. Por favor, que no se hable nunca más de terrorismo vasco, el terrorismo es de ETA y a un vasco de buen corazón, a un vasco con dignidad, jamás se le ocurriría matar ni extorsionar a nadie. No son vascos de ninguna manera quienes cometen estas atrocidades; son simplemente alimañas, son simplemente asesinos. ETA, estoy absolutamente convencido, está escribiendo su final, estoy absolutamente convencido de esto, porque es increíble que en el siglo XXI nadie pueda pensar que se puede defender nada pegando tiros, matando y extorsionando a los demás». La pretensión de ETA había sido la de acabar con la democracia e impedir la libertad de expresión. Ibarretxe pedía no utilizar la violencia de ETA con fines partidistas y llamaba a manifestarse contra ETA «sin comunicados, sin nada que pudiera diferenciarnos a unos de otros». Al final de su declaración volvía a insistir en lo que parecía su principal obsesión: "Quiero decirle fundamentalmente hoy a la sociedad española que el pueblo vasco ha sido, es y seguirá siempre siendo un pueblo civilizado, un pueblo amante del diálogo, amante de la relación con las personas, respetando los derechos fundamentales, respetando la vida, respetando las formas de pensar de cada cual. Quiero enviar un abrazo fraterno a todas las víctimas de esta barbaridad tremenda que hemos visto hoy en Madrid».

El comunicado del PNV apostaba por «la defensa de la democracia y la libertad frente a la barbarie y el totalitarismo ... La unidad de la sociedad para acabar con ETA y el acuerdo de las fuerzas políticas, es hoy más que nunca necesario para consolidar la convivencia y hacer frente a ETA».

Otegi rechazó el atentado, que calificó de masacre, y afirmó que «ni por los objetivos, ni por el modus operandi se puede afirmar que ETA esté detrás de lo que ha ocurrido». Asimismo, sugirió que los responsables podían ser «sectores de la resistencia árabe. El Estado español mantiene fuerzas de ocupación en Irak y no hay que olvidar que ha tenido una responsabilidad en la guerra de Irak». Un comunicado de la izquierda abertzale ratificó por la tarde cuanto había dicho Otegi por la mañana. Por su parte, el responsa- 
ble de Batasuna en el País vascofrancés negó también la responsabilidad de ETA y consideró que los atentados carecían de justificación.

La presidenta de EA, Begoña Errazti, condenó la masacre y exigió que no se aprovechara para ir en contra de «ideas ni de pueblos». "Sólo cabe la denuncia, dijo, y exigir que no vuelva a suceder. Sin embargo, si es del mundo del Islam está claro qué consecuencias ha tenido la guerra de Irak, $\mathrm{y}$, si ha sido de ETA, no tiene legitimidad para actuar en nombre del pueblo vasco».

Madrazo exigió a ETA su disolución inmediata. «ETA podrá seguir matando, pero está acabada, social y políticamente, porque las sociedad vasca les rechaza y les desprecia. Con esta muestra de brutalidad, en el fondo deja patente su debilidad... ETA pone de manifiesto el fanatismo y el totalitarismo más cruel. Los atentados recuerdan el modus operandi de Al Qaeda, a más muertos más impacto».

Mientras Maragall abogó por votar libremente el domingo para evitar que el terrorismo dividiese a la sociedad, Carod Rovira manifestó que «en Irlanda y en Córcega llegaron a la conclusión de que por la vía policial y judicial exclusivamente no se ponía fin a la violencia... alguien en algún momento, en los de mayor atrocidad, rabia y dolor como es hoy - por ayer-, deberá tomar una decisión valiente y hablar con quien mata para que deje de hacerlo. Es que no existe otra vía».

El lema escogido para la manifestación fue «Con las víctimas, con la Constitución, por la derrota del terrorismo», que no gustó ni al PNV ni a EA. Esta última lo calificó de «sectario y excluyente» ${ }^{86}$.

Al día siguiente de la matanza, ETA negó toda responsabilidad sobre el atentado a través de un comunicante anónimo, al que Batasuna concedió absoluta credibilidad. Otegi (de manera cínica) consideró indignante que la clase política vasca «fuera capaz de atribuir a una organización el atentado y de paso intentar el asesinato político de la izquierda abertzale». La credibilidad del PNV, EA, Ezker Batua y Aralar había quedado en entredicho, añadió Barrena, «al basar su discurso en la versión policial». Begoña Errasti (en una interpretación disparatada que identificaba al pueblo vasco con ETA) pidió responsabilidades al gobierno central por «no mostrar realmente todos los datos y criminalizar una vez más al pueblo vasco».

El gobierno, por su parte, mantenía abiertas todas las hipótesis, aunque daba mayor veracidad a la pista de ETA. Esto no coincidía con lo que afirmó el ministro de Interior francés, para quien la hipótesis de ETA había dejado de ser prioritaria.

${ }^{86}$ El Correo 12-3-04, (28,29,30,31,40,47,48,37,38,39,44,45,46). No se tiene en cuenta la declaración institucional del Congreso por ser irrelevante para el caso. 
La oposición, además de pedir a Aznar claridad y rapidez de información sobre la autoría, comenzó a manifestar ciertas preocupaciones y, en algunos casos, acusaciones sobre la información del gobierno. Para Zapatero, los «caminos de respuesta» serían muy diversos según fuese ETA o un grupo afín a Al Qaida y José Blanco insinuó que el gobierno ocultaba información y que intentaría ocultarla hasta después de las elecciones. «La gente - añadió - no puede acudir a las urnas bajo la duda y la sospecha». También Ibarretxe pidió información «fehaciente», añadiendo que la distinta autoría podía dar lugar «a una valoración política diferente». Azkarraga, de EA, fue más allá al unir la guerra de Irak y el intento del PP de mantener la duda sobre la autoría de los atentados hasta después de las elecciones por «motivos electorales». Además, Acebes y Zaplana habían prevaricado al acusar a ETA sin pruebas. Madrazo censuró la gestión de la información «en función de intereses partidistas». Carod Rovira, por su parte, estaba convencido de que el gobierno trataría de manipular lo ocurrido «para no modificar ni un milímetro la línea argumental de su campaña». Conocer la verdad del caso el día 15 sería un «fraude moral».

Fuentes socialistas, según Ramón Gorriarán, sostenían que la actuación unilateral del Partido Popular respecto a la estrategia antiterrorista a seguir después de las elecciones llevaba al absurdo de que «el resultado de las elecciones del domingo esté influido por el hecho de que el autor de los atentados sea ETA o Al-Qaida».

Rajoy asumía las informaciones del ministro del Interior, por lo que la prioridad en la investigación era ETA, aunque había otras posibilidades que no podían cerrarse. Ibarretxe criticó la consigna para encabezar la manifestación de Madrid, pero pidió el apoyo ciudadano al margen de los lemas. Y, fuese ETA o no la responsable del atentado, manifestó que no retiraba ninguno de los apelativos que dedicó a ETA en su primera comparecencia. Mayor Oreja, por su parte, se sintió avergonzado por las declaraciones de Ibarretxe, porque no hacían falta vascos que llorasen, sino vascos que no hiciesen planes de ruptura con la Constitución, sino con ETA. «Ayer - añadió - tuve las sensación de que algunos estaban más empeñados en confirmar que no era ETA, para que luego la ruptura con la Constitución fuese más fácil, que en estar de verdad con las víctimas y contra lo que significa hoy una organización terrorista como ETA» ${ }^{87}$.

Aunque no cabía encajar en la totalidad de estas declaraciones lo dicho por Rafael Larreina (Eusko Alkartasuna), lo cierto fue que el secretario de EA explicó el alivio de los vascos por el «doble acoso que sufren los vascos, el de ETA y el de los que nos acusan a todos de connivencia con el

87 El Correo 13-3-04, (19.18,20,28,29). 
terrorismo... Hay una preocupación de que nos confundan y por eso, cuando se supo que podía ser Al-Qaida, pues muchos pensamos que los vascos no íbamos a ser esta vez el malo de la película» ${ }^{8}$.

A Ramón Jáuregui le parecía comprensible sentirse manchado por el terrorismo, «porque ETA no es un grupo terrorista del Camerún, sino el de aquí. Es el terrorismo de la causa nacionalista, por mucho que algunos quieran negarlo. Es verdad que hasta ahora no habían pasado cierto límite. Pero todos sentimos que eso habría sido perfectamente posible» ${ }^{89}$.

El día de las elecciones (día 14) la prensa comunicaba que Al-Qaida se había atribuido en un vídeo la matanza de Madrid. Grupos de manifestantes se concentraron ante las sedes del PP en diversas ciudades gritando no a la guerra y mentirosos y pidiendo la verdad antes de votar. Las concentraciones fueron convocadas a través de mensajes de móvil y de Internet y se realizaron durante la jornada de reflexión. En la que tuvo lugar en Vitoria hubo afiliados y cargos del PNV, PSE e IU.

La oposición, por su parte, había pedido durante el día anterior transparencia al gobierno. IU protestó ante la Junta Electoral Central por las manifestaciones de Rajoy, en las que, ante la gravedad de los acontecimientos, había pedido, supuestamente, una mayoría absoluta, y acusó al PP de desinformar y manipular. Tanto el PSE - había que conocer la verdad antes de votar para no lamentar nada el lunes - como los integrantes del Gobierno Vasco fueron contundentes en sus demandas al gobierno central. Imaz acusó al gobierno de estrategia de confusión y de ocultamiento de información y consideró inmoral que el gobierno pudiese escamotear datos para evitar un disgusto electoral.

También el PP recurrió a la Junta Electoral por la manifestación «ilegal e ilegítima» ante su sede central en Madrid y la Junta elevó al fiscal la queja del PP. Rajoy denunció que las manifestaciones contra sus sedes estaban destinadas a influir negativamente en el voto y pidió a los electores «votar libremente y sin sentirse coaccionados como mejor defensa contra el terror» ${ }^{90}$.

Fue Rubalcaba quien acusó al gobierno de ocultar información y decir cosas que no se ajustaban a la verdad. El gobierno habría actuado manipulando los datos, datos «que no estaban en consonancia con la marcha de las investigaciones» que ya conocía la oposición socialista antes de que el gobierno informara de las primeras detenciones de islamistas. Según esto, añadió Rubalcaba, «los españoles se merecen un Gobierno que no les mien-

88 El Correo 13-3-04 (24).

${ }^{89}$ El Correo 13-3-04 (24 y 25).

90 Ver para estas informaciones: El Correo 14-3-2004 (28 y 29). No consta en esta última información que Rajoy pidiese, ante las graves circunstancias, la mayoría absoluta. 
ta, un Gobierno que les diga siempre la verdad», porque la magnitud del crimen no admitía el juego político, sino la limpieza. Toda la verdad se acabaría sabiendo, añadió, y «ése es nuestro compromiso con las víctimas». El PSOE felicitó a las fuerzas policiales por las detenciones, se comprometió a convocar después de las elecciones a todas las fuerzas políticas para reconstruir la unidad ante el terrorismo y, por último, pidió a los ciudadanos que acudiesen a votar para así homenajear a las víctimas.

Por primera vez desde la democracia, informaba El Correo, las elecciones generales estaban marcadas por la incertidumbre ante la reacción ciudadana tras la tragedia. ${ }^{91}$.

\section{Editoriales}

Dos son las palabras clave que resumen el análisis del periódico sobre las elecciones: democracia y antiterrorismo. Incluso dos editoriales dedicados al comentario de uno de los sondeos electorales y a la actitud de la oposición ante el Plan Hidrológico Nacional desarrollaron elementos y valores propios de la democracia. La defensa de la democracia y sus valores - libertad, participación ciudadana, debate de la cosa pública, interés general, salvaguarda de las instituciones, unidad de los partidos en lo común - y el antiterrorismo - rechazo del uso electoral del terrorismo y del diálogo con los terroristas, no a la discusión pública sobre terrorismo entre partidos en las elecciones, crítica del papel del nacionalismo, unidad de los partidos contra el terrorismo- se distribuyeron de manera semejante el espacio dedicado al análisis de los problemas a los que se enfrentaban las elecciones. El valor político principal, la democracia, frente a su negación, el terrorismo. El periódico huyó de las formas estridentes, pero interpretó correctamente la campaña, cuando destacando las dos cuestiones a las que me refiero, censuró las estrategias electorales y políticas de fondo de los grandes partidos y del nacionalismo y las técnicas de descalificación, que implicaban la negación de valores democráticos o al menos su puesta en peligro ante los ciudadanos. En este sentido se escribieron los nueve editoriales del tiempo de la campaña, número semejante al de las complejas elecciones autonómicas vascas de 2001. En el inicio de la campaña el periódico hizo la advertencia de que la participación y el pluralismo necesitaban del debate y no de la exageración de las diferencias o el tremendismo, porque con ello sufría el sistema político con sus libertades, bienestar, concordia general y unidad contra la intolerancia y el terrorismo.

91 Ver para las declaraciones de Rubalcaba y demás informaciones: El Correo 14-3-04 (30, 34 y 35$)$. 
Tales advertencias constituían su programa de campaña y su criterio de interpretación de las intervenciones de los partidos, que incluían -única excepción en una ausente petición del voto- el rechazo del voto nulo a Batasuna por su concomitancia con el terrorismo y el rechazo del diálogo con ETA defendido por el nacionalismo. La censura más severa y frecuente, en primer lugar, fue contra todo tipo de terrorismo, especialmente el de ETA y su aliada Batasuna. En segundo lugar, contra el nacionalismo y los partidos políticos nacionalistas. En tercer lugar, contra los partidos de la oposición. Y, por último, contra el Partido Popular, aunque las diferencias entre la oposición y los populares fueron mínimas.

En cuanto al nacionalismo, como ocurrió en otras campañas, no fue más allá de la crítica a sus estrategias y tácticas. De ninguna manera analizó su naturaleza actual, que supondría discutir su legitimidad. Lo mismo cabe decir de su llamada a la defensa de la democracia. Lo que el periódico hizo fue mantener una posición doctrinal o teórica sobre la democracia y, en su nombre, censurar las estrategias de campaña de los partidos. Expuso el deber ser, pero no se comprometió, en la denuncia específica, ni puso nombres a todos aquellos, partidos y políticos - salvo los de ETA y Batasuna o, en casos de menor entidad, los de los grandes partidos-, que conculcaron de manera exagerada los más elementales principios democráticos, tal y como lo hizo el PP con su tesis del contubernio socialista-nacionalista, el Partido Socialista con su denuncia de una derecha responsable hasta de la radicalidad del PNV y de los asesinatos de la violencia de género o los nacionalistas con su fundamentalismo e interpretación de que el desafío de la legislatura siguiente era el de la regeneración del deterioro democrático.

«Cita con la libertad» es el título del editorial que inicialmente consideraba a la democracia española como estable y plenamente madura. Las elecciones eran una oportunidad más para el ejercicio de la democracia. Aunque el ejercicio del derecho al voto no era la única forma de participación, ni las alternativas propuestas a los electores agotaban sus expectativas, el momento más participativo y pluralista de la vida pública era el de elegir la opción y los representantes de la siguiente legislatura. No obstante, las campañas de los partidos acostumbraban a marginar al conjunto de la ciudadanía para dirigirse fundamentalmente a movilizar el voto más próximo y fiel. La ausencia de confrontación entre los candidatos y la falta de debate reducía las posibilidades de la campaña como tiempo de participación política. Las incógnitas de las elecciones eran la del vencedor (PP o PSOE) y la de la mayoría absoluta o no.

El editorial advertía que la exageración de las diferencias entre los candidatos o el uso del catastrofismo en lugar del contraste razonado entre distintas opciones hacía sufrir a la democracia y a la concordia social. Y era esencial que las diferencias no redujesen la confianza de los ciudadanos en 
el sistema de libertades, en el bienestar, en la concordia general y en el esfuerzo común contra el terrorismo y la intolerancia.

En Euskadi las elecciones tendrían un carácter especial derivado de la interpretación que se haría de los resultados a la luz del plan de Ibarretxe - resultados favorables o desfavorables - y, sobre todo, de la presencia de la ilegalizada Batasuna pidiendo el voto nulo. Esta última constituía el reto principal de las elecciones — «dada su concomitancia con la continuidad del terrorismo»- al que todos los demás partidos debían responder comprometiéndose, para lograr la «enésima derrota política de ETA», a que el voto nulo fuera el mínimo posible.

También en Cataluña los partidos democráticos estaban «obligados a evitar que un hipotético ascenso electoral de ERC (pudiese) ser interpretado por los más radicales como aval para el acercamiento y el diálogo con ETA» ${ }^{92}$.

Un segundo editorial del mismo día - comentando la manifestación de Barcelona contra ETA originada por la exclusión de Cataluña de los actos de terrorismo, a la que habían asistido todos los partidos democráticos catalanes menos el Partido Popular y las asociaciones contra el terrorismo - resaltaba que si bien no se podía aceptar la interpretación de Rajoy de que la concentración de Barcelona era un acto de «legitimación de la negociación con ETA», tampoco se podía eximir del todo a la convocatoria de estar manipulada por quienes podían alegrarse de las ausencias. La ocasión debía ser un motivo de reflexión sobre lo que era eficaz en la lucha contra ETA. El terrorismo era una tentación para el uso partidista y, en este sentido, «resultaría hipócrita imputar tal instrumentalización a quienes no asistieron a la cita de ayer. Entre otras razones porque ello justificaría la formulación de una imputación análoga contra quienes la convocaron» ${ }^{93}$.

El sondeo de TNS-Demoscopia daba al PP entre 174 y 177 escaños, al PSOE entre 133 y $137^{94}$, y una diferencia de cinco puntos porcentuales (42,2\% PP frente al 37,2\% PSOE), que suponían una bajada de un 2,3\% para el PP y un ascenso del 3\% para el PSOE con respecto a las elecciones anteriores. En relación al País Vasco los resultados serían los mismos que en las elecciones generales anteriores: 7 PNV (32,6\%), 7 PP (24\%), 4 PSOE $23,3 \%$ y 1 EA (7,2\%). El editorial de El Correo destacaba que los resultados anunciados se correspondían con un Rajoy como candidato más valorado y con un modelo de Estado en el que se imponía el discurso de estabilidad institucional frente a las propensiones reformadoras. Casi la mitad de los encuestados (46\%) optaba por el vigente modelo autonómico.

\footnotetext{
92 El Correo 27-2-04 (31), editorial «Cita con la libertad».

93 Ibidem.

${ }^{94}$ El Correo 29-2-04 (28) y 1-3-05 (16).
} 
Sólo un 6\% optaba por el plan Ibarretxe. La ventaja del candidato «continuista» estaba relacionada también con la percepción positiva sobre la marcha de la economía. El 66\% veía a Rajoy como el siguiente presidente de Gobierno. En esta opinión coincidía el 59\% de los votantes del PSOE. Sólo un $10 \%$ creía que Zapatero ganaría las elecciones. Las consideraciones del editorial terminaban con una prudente observación: «Las encuestas, en todo caso, son instantáneas efímeras de la realidad sociopolítica. La única relevante e inamovible será la que dibuje el pueblo soberano en las urnas el próximo día 14. Hasta entonces, todas las posibilidades estarán plenamente abiertas, en espera de que los ciudadanos digamos la última palabra» ${ }^{95}$.

El editorial del 1 de marzo comentó la acción de la Guardia Civil que había detenido a varios miembros de ETA en Cuenca y evitado una catástrofe en Madrid. En el comentario subyacía, sin ningún tipo de mención expresa, la reciente entrevista de Carod con ETA, lo que permitía al editorialista destacar la ayuda voluntaria o involuntaria que daban a la organización terrorista los que se acercaban a ella así como los que defendían la necesidad de dicho acercamiento. La abominable tregua de Cataluña no pretendía más que aumentar la crueldad de la violencia fomentando sentimientos encontrados en España. La última baza de ETA era la división de los que repudiaban y combatían el terrorismo. Por ello - mucho más en unas elecciones - debía imponerse la cordura y el rechazo del terrorismo como argumento de pugna partidista. ETA se hundía en su propia espiral y la eficaz actuación policial y judicial estaba generando el efecto contrario al que pretendía ETA. Si ésta pretendía justificar su existencia, lo que se venía evidenciando era su sinrazón y sinsentido, incluso entre sus antiguos seguidores. «Pero a pesar de ello conviene recordar que, junto al diálogo propugnado desde la interesada temeridad de algunos sectores del nacionalismo, ETA contará con un balón de oxígeno si continúa acaparando la atención del debate público y provocando el enfrentamiento entre los demócratas» ${ }^{96}$.

Los atentados contra el ayuntamiento y la sede socialista en Cornellá dieron ocasión a un nuevo editorial, que llamaba a preservar la unidad de los partidos en el tema de la violencia. Si bien el debate sobre el terrorismo era ineludible, la forma de llevarlo a cabo con reproches y acusaciones de falta de honestidad y coherencia en la lucha contra ETA era más que discutible. Era pernicioso y reprochable para los ciudadanos que los partidos se sometieran a un juicio de intenciones. Y era imprudente que el debate derivara en plena campaña sobre la necesidad o no de la revisión del acuer-

95 El Correo 29-2-04 (41), editorial «Clara ventaja del PP».

96 El Correo 1-3-04, editorial «Alivio e inquietud». 
do por las libertades y contra el terrorismo. Si bien el diálogo era necesario entre los partidos democráticos, sería un error hacerlo en plena campaña electoral. Más prudente sería, para debatirlo después de las elecciones, recuperar la unidad «esforzándose por evitar la exageración o la tergiversación de los factores de divergencia, aportando un mayor sosiego y rigor al debate público sobre el terrorismo y precisando qué actitudes resultan compatibles y cuáles incompatibles contra ETA» ${ }^{97}$.

La utilización en la campaña de las reservas que algunos documentos internos comunitarios atribuían al Plan Hidrológico Nacional y, en concreto, al trasvase del Ebro, reservas que se referían al impacto medioambiental del trasvase y al sistema de contratación de obras, mereció un editorial claramente favorable a la política del PP en el que se afirmaba que «lo fundamental es que un trasvase de caudal que debería ser entendido como una infraestructura solidaria y cohesionadora, se haya transformado en un debate partidista y estéril. La necesidad de suministrar agua a la España de la vertiente mediterránea, incluida Cataluña, sin hacerlo a costa de las necesidades y aspiraciones de Aragón y el Bajo Ebro, no es ocurrencia de este Gobierno, ni siquiera problema suscitado en este siglo. Tras eternas disputas y prolongados desencuentros, al final se ha impuesto la opción del trasvase de parte del caudal del río hacia el este y sur peninsular. Quizá no fuera la única, pero a falta de alternativas solventes para resolver la sed del litoral mediterráneo en mejores condiciones ecológicas y económicas, las maniobras para debilitar la posición española en su petición de ayuda comunitaria (1.262 millones sobre 4.207) hacen un flaco servicio al interés general» ${ }^{98}$.

El atentado de Madrid fue analizado de urgencia en un editorial que, entre otras cuestiones, destacó las coincidencias entre todos los terrorismos, los errores en el tratamiento de los terroristas (diálogo, etc.) y la necesidad de la unidad. El editorial no hablaba de quiénes eran los autores de la matanza, pero implícitamente era una acusación contra ETA, así como una censura contra los nacionalismos de EA y PNV. Sobre lo primero decía el editorial: «El asesinato en masa de ayer demuestra hasta qué punto puede llegar a ser cierto que todos los terrorismos responden al mismo patrón fanático; que todos los terrorismos persiguen inocular en los ciudadanos sensaciones de inseguridad que hagan de las sociedades libres comunidades desvalidas y vulnerables ante la intolerancia extrema». Sobre el diálogo y la unidad defendía que «la palabra diálogo constituye una ofensa a la dignidad humana cuando se postula que quienes perpetraron la matanza de Madrid sean los interlocutores. La presunción de que los paladines de

97 El Correo 2-3-04, editorial «Preservar la unidad».

98 El Correo 11-3-04 (29), editorial «Plan Hidrológico y campaña». 
la muerte actúan motivados por ideales políticos mancilla el recuerdo de cuantas mujeres y hombres han sido asesinados. Los remilgos de quienes tratan de diferenciarse del terror sin importunar en exceso a sus ejecutores representan una afrenta hacia quienes tienen razones más que fundadas para sentirse acosados por su violencia. La masacre de ayer obliga a la unidad. Pero la unidad no puede construirse de espaldas a las víctimas de la masacre. Como si, una vez identificados los cadáveres, los representantes públicos pudieran medir sus pasos en función de uno u otro cálculo político. Por eso mismo, nadie puede escurrir el bulto ante la convocatoria de las movilizaciones convocadas para esta tarde alegando disconformidad con lemas o recorridos porque no hay nada más urgente que la manifestación de un clamor unánime contra el terror. Como tampoco puede nadie pretender que la ciudadanía acuda el domingo a votar olvidándose de una realidad tan aterradora como la amenaza terrorista. Porque también para ese día lo urgente será que la masiva participación electoral acabe acorralando al terrorismo como un mal que ha situado a España en uno de los primeros lugares de la barbarie a nivel mundial» ${ }^{99}$.

El editorial del día 13 pedía la unidad de partidos e instituciones para combatir el terrorismo, el esclarecimiento de la identidad de los autores para ponerlos a disposición de la justicia y la reducción a cero de la abstención. Por otra parte, afirmaba que «la existencia de indicios que descartarían la responsabilidad de la banda terrorista ETA en la masacre y que apuntaría a la actuación de un grupo estructurado y ligado al fundamentalismo islamista obliga a los responsables institucionales a una actuación más acorde con la amenaza precisa que tan inquietante novedad introduciría no sólo en España sino en todo el ámbito de la Unión Europea». El sufragio y la libre elección de los representantes era el polo opuesto de lo que querían los terroristas, de ahí que la respuesta ciudadana debía ser la de reducir a la nada la abstención ${ }^{100}$.

Frente al terrorismo, concluyó El Correo en el editorial del día 14, que querría un mundo sin urnas, sin derechos y sin libertad, estaban la libertad de conciencia y de opción política, fundamentos de las elecciones democráticas. La libertad compartida por todos los partidos políticos hacía insignificantes, prescindibles y subordinados los demás argumentos. El editorial llamaba a los ciudadanos a participar, porque cuantos más lo hiciesen, más fortalecida saldría la democracia, y sólo tácitamente se refirió a la responsabilidad del terrorismo islamista. Comentando los sucesos del día de reflexión, escribió: «... no estuvo exenta (la jornada) de tensiones y comparecencias públicas que reflejaron el estado de ánimo de una

99 El Correo 12-3-04 (52), editorial «Asesinato en masa».

100 El Correo 13-3-04 (33) editorial «Unidad frente al terror». 
sociedad y de una clase política conmocionadas por el golpe terrorista del pasado jueves. Algunas de esas manifestaciones públicas vulneraron los requisitos que la ley tiene previstos para asegurar el preámbulo de unas elecciones que se desarrollen en un clima de serenidad y libertad. Por eso mismo resulta imprescindible que a lo largo del día de hoy los ciudadanos puedan ejercer su derecho al voto de forma masiva sin que la jornada se vea enturbiada más que por la lógica emoción que embarga a la sociedad española» ${ }^{101}$.

El último editorial, si bien atribuía parte de la explicación de la victoria del PSOE y derrota del PP al atentado terrorista que habría provocado un aumento de la participación electoral y una contestación al gobierno de Aznar, defendía que la explicación no podía considerarse únicamente como efecto del 11-M. Había que tener en cuenta, además, el reproche de la opinión pública por la gestión informativa del 11-M y, también, la reducción de las distancias del PSOE con respecto al PP que venían indicando las últimas encuestas. «El voto que los socialistas no conseguían movilizar a su favor acabó apoyando a Rodríguez Zapatero como muestra de censura al partido en el Gobierno». La primera tarea del Gobierno sería buscar el consenso en torno al problema de la seguridad. La falta de mayoría absoluta obligaría al PSOE a buscar alguna alianza parlamentaria, pero sería imprescindible, para la lucha contra el terrorismo, el progreso económico y social y una política territorial adecuada, que los dos grandes partidos lograsen elaborar una política de Estado. El periódico esperaba por el estilo del nuevo presidente un tiempo político basado más en el diálogo que en la confrontación y reconoció la actitud serena y responsable del PP en la noche de su derrota ${ }^{102}$.

\section{Colaboraciones}

El total de comentarios que ofreció El Correo durante la campaña fue de $85^{103}$. La mayor parte de éstos, sesenta, ocupó las páginas del periódico hasta el día 11. A partir de este momento, la catástrofe de Madrid polarizó prácticamente el resto de comentarios. Varias razones - la naturaleza regional del periódico, el doble planteamiento nacional y nacionalista de los partidos en la campaña en el País Vasco, la utilización constante del nacionalismo en la argumentación de los populares y, en

\footnotetext{
101 El Correo 14-3-04 (37), editorial «A las urnas».

102 El Correo 15.3.04, (23), editorial «Cambio tranquilo».

103 Sólo se tienen en cuenta los comentarios firmados que guardan relación con el objetivo de este trabajo.
} 
menor medida, de los socialistas, y la gravedad objetiva que representaban las diversas manifestaciones del nacionalismo vasco, especialmente, el terrorismo de ETA - pueden explicar que algo más de la mitad de las colaboraciones tocaran en sus comentarios cuestiones relacionadas con el nacionalismo. Esta relación aumentó muy notablemente al analizar la tragedia de Madrid.

Si bien todos los comentarios tienen que ver con las elecciones, lo hacen de forma distinta. La mayoría son específicamente electorales, porque sus contenidos tratan cuestiones de la campaña como, por ejemplo, los objetivos electorales y políticos de los partidos o los errores de los candidatos. Otros comentarios no se refieren directamente a los protagonistas de la campaña, los partidos, sino a agentes externos que influyen en el desarrollo de las elecciones como la actitud de los obispos a favor del Partido Popular. Otros artículos pretenden destacar las lagunas o ausencias de la campaña, bien personales o temáticas, como por ejemplo, el problema de la inmigración. Y, por, último, hay artículos que se pueden entender como artículos de fondo, que, si bien tienen relación con las elecciones, por su contenido trascienden a las mismas, como ocurre con el análisis del fundamentalismo nacionalista. Todos estos últimos artículos giran sobre diferentes cuestiones del nacionalismo.

\section{A) Comentarios anteriores al 11 de marzo}

Los comentaristas se centraron básicamente en los dos grandes partidos nacionales, el nacionalismo y ETA. IU tuvo muy poca atención y la poca que tuvo, salvo en contadas ocasiones, fue crítica negativa ${ }^{104}$. El Partido Popular fue tratado en 22 ocasiones, de las que 13 tocaron aspectos técnicos y 9 fueron censuras. En el caso de los socialistas (PSOE y PSE)

104 Las alusiones a IU fueron por la defensa de Madrazo de exportar la fórmula de coalición del Gobierno vasco y catalán a Madrid; por el voto útil socialista, que ella misma favorecía con su estrategia de ataque a la mayoría del PP; por las acusaciones al PP de manipulación de la justicia; por haber animado la campaña con sus generosas promesas y por haber afirmado Madrazo que la tregua de ETA en Cataluña era un intento de regalar la mayoría absoluta al PP, que mereció el irónico comentario de que ETA con sus dos furgonetas cargadas de explosivos y detenidas por la Guardia Civil en la carretera de Guadalajara había intentado mejorar aún más las posiciones del PP. Al autor del comentario se le escapaban las sutilezas analíticas del sagaz Madrazo y se preguntaba si Ternera y Antza no serían del Partido Popular. «¿Está seguro Madrazo de no ser él mismo un miembro de los servicios de inteligencia - ustedes perdonen - del Gobierno y un propagandista del PP?» (El Correo 1-3-04, p. 20, «Pepemanía», Santiago González). Ver, también, El Correo 27-2-04 (23), «La normalidad es una corbata», Florencio Domínguez; 4-3-04 (20), «Utilidad», Kepa Aulestia; 5-3-04 (22), «Utilina», José Luis Zubizarreta; 5-3-04 (24), «Vuelve Madrazo», Santiago González; 8-3-04 (23), «Calentón», Lorenzo Silva. 
hubo, también, 22 menciones, de las que 10 fueron técnicas y 12, críticas negativas. El nacionalismo incluía a todos los partidos nacionalistas vascos y catalanes y alcanzó la cifra de 48 alusiones, teniendo el PNV la atención preferente en 34 ocasiones, de las que 12 fueron técnicas y el resto críticas, todas ellas censuras, salvo en algún caso. La crítica negativa a ETA apareció en 5 ocasiones al comienzo de la campaña a propósito de la entrevista de Carod Rovira y la posterior manifestación de Barcelona.

Con respecto al nacionalismo los analistas destacaron: la inquietud de EA e IU de que el PNV se hiciera con los réditos obtenidos con ellos; la pugna que se vivía en el PNV ante la posibilidad de que las primeras elecciones en la época de Imaz fueran un fracaso; la identificación de la normalidad en Euskadi con el hecho de tratar el plan de Ibarretxe; la confusión de los nacionalistas catalanes convocantes de la manifestación de Barcelona; el objetivo electoral del nacionalismo de comprobar el fortalecimiento o debilitamiento social del proyecto nacionalista, que, en el supuesto de un triunfo por mayoría absoluta de los populares, obligaría al nacionalismo a conseguir una mayoría absoluta en el Parlamento vasco para dar lugar a una confrontación entre legitimidades; el riesgo de que EA perdiese el único escaño que tenía - lo que afectaría gravemente a su proyecto político y a la misma existencia como partido - y forzaba su estrategia de marcar distancias con el PNV acusándole de que era poco de fiar y de que EA era la garantía del plan Ibarretxe; la posibilidad de intereses comunes entre el PSE y el PNV, que se habría fortalecido con la presidencia de Imaz, pero que de momento el PNV rechazaba con su estrategia de considerar idéntica la política del PP y del PSOE; el significado de segunda vuelta de las elecciones autonómicas que tenían las elecciones en Cataluña, donde el hundimiento de CIU podía enaltecer a ERC y donde Carod tenía que luchar contra los que dentro de su partido la acusaban de populista; los intentos de EA y Aralar de buscar en el País Vasco un espacio más nacionalista y de izquierda que el del PNV, que exigía actuar con rapidez, ya que, si bien la existencia de ETA no garantizaba su permanencia entre el abertzalismo y el PNV, la desaparición o marginalidad de ETA la haría más incierta aún; y la nula incidencia de lo «nuestro», de la «referencia vasca» en unas elecciones que enfrentaban a la izquierda y a la derecha españolas, a pesar de lo importantes que se creían los partidos nacionalistas vascos.

Las críticas a los partidos nacionalistas insistieron en: el victimismo de los nacionalistas vascos y en la pretensión de Imaz de presentar el voto al PP o al PSOE en Euskadi como el voto del limbo, ya que el único que llevaba al Congreso la voz de Euskadi era el PNV; en la exigencia de Imaz de devolver con urgencia a los vascos la democracia que el PP les habría arrebatado; en la importancia, desmentida por los hechos, que se atribuían 
los partidos nacionalistas; y en que lo único que importaba al gobierno vasco (al nacionalismo vasco) era el plan Ibarretxe ${ }^{105}$.

Hubo varias cuestiones que merecen un apartado en esta visión crítica del nacionalismo vasco. La primera se refiere a la autodeterminación sobre la que se comentó, a propósito de que se iban a repetir en el País Vasco los mismos resultados que en las últimas generales, 11 para los constitucionalistas y 8 para los nacionalistas - la diferencia sería mayor si se tuviesen en cuenta los resultados de Navarra-, que con tales mimbres ETA y los suyos querían hacer de la minoría nacionalista la representación

105 Ver para todos los resúmenes de las colaboraciones: El Correo 27-2-04 (22), «A dos bandas», Kepa Aulestia; (23), «La normalidad es una corbata», Florencio Domínguez; El Correo 28-2-04 (24), «No más ETA, por favor», José Luis Zubizarreta; El Correo 28-2-04 (26), «Manifestapena», Santiago González; El Correo 28-2-04 (28), «Sin acento catalán», Tonia Etxarri; El Correo 27-2-04 (26), «Desafíos electorales», Xavier Gurrutxaga; (32), «Los políticos» (32), de F.L. Chivite; El Correo 29-2-04, «Valor de cambio», Kepa Aulestia; El Correo 29-2-04, «La raya nacional», Florencio Domínguez; El Correo 29-2-04 (34) «Decisiones arriesgadas», Xavier Gurrutxaga; El Correo 1-3-04 (18), «Con la mano en el corazón», José Luis Zubizarreta; El Correo 1-3-04 (19), «Zapatero, de dos en dos», Tonia Etxarri; El Correo 2-3-04 (23), «Marcar territorio», Florencio Domínguez; «Dos manos», de Kepa Aulestia, es un artículo sobre el reparto de papeles en la campaña del PP; El Correo 2-3-04 (29), «Por favor», Lorenzo Silva; El Correo 3-3-04 (20), «Creer y querer», José Luis Zubizarreta; El Correo 3-3-04 (21), «Tan cerca de Cuenca», Tonia Etxarri; El Correo 3-3-04 (22), «Informe innecesario», Santiago González; El Correo 3-3-04 (24), «Al sur de Despeñaperros», Lorenzo Silva; El Correo 4-3-04 (20), «Utilidad», Kepa Aulestia; El Correo 4-3-04 (21), «Guiños sin respuesta», Florencio Domínguez; El Correo 4-3-04 (22), «Ver y creer», Xavier Gurrutxaga; El Correo 5-3-04 (26), «El guardián de mi hermano», Tonia Etxarri; El Correo 6-3-04 (22), «Catalanas», Kepa Aulestia; El Correo 6-3-04 (24), «Cuando los aliados estorban», Xavier Gurrutxaga; El Correo 6-3-04 (25), «Derrotar a ETA», Florencio Domínguez; en p. 30, artículo de Lorenzo Silva, «José María el Católico», y en p. 34, artículo de José Luis de la Granja Sainz, «Aguirre, carisma y pragmatismo»; El Correo 7-3-04 (28), «Silencios de campaña», José Luis Zubizarreta; «El giraldarra», artículo de Santiago González, destacaba los dos pesos, las dos medidas, los dos criterios diametralmente distintos que aplicaba ETB a las noticias según fueran favorables o contrarias al nacionalismo; El Correo 7-3-04 (32), «La Euskadi que bosteza», Tonia Etxarri; el artículo de Lorenzo Silva, «Flashback», destacaba que el protagonismo de la campaña no lo tenían los candidatos, sino los «ex» Felipe González y Aznar, que dificultaba la atención al discurso de los candidatos, muy de centro, además de difuso y tenue, a sabiendas de que los electores que les harán ganar o perder respondían más al bronco discurso de los exlíderes; El Correo 8-3-04 (16), «Letra pequeña», Kepa Aulestia; El Correo 8-3-04 (19), «Centenario de Aguirre», Florencio Domínguez; El Correo 8-3-04 (23), «Calentón», Lorenzo Silva; El Correo 9-3-04 (20), «Genio y figura», José Luis Zubizarreta; El Correo 9-3-04 (22), «Hablar o no hablar», Santiago González; El Correo 9-3-04 (24), «Que nadie se relaje», Tonia Etxarri; El Correo 9-3-04 (28), «¿Pasa algo?», Lorenzo Silva; El Correo 10-3-04 (20), «Ritmo», Kepa Aulestia; El Correo 10-3-04 (26), « ¿Y ese debate?», Lorenzo Silva; El Correo 11-3-04 (22), «Cinci...qué», José Luis Zubizarreta; El Correo 11-3-04 (24), «Ya llegará el 15, ya», Tonia Etxarri; en p. 30, «Promesas más exigencias, igual a rebajas», art. de Joseba Arregi, que describe de forma general una de las características de las campañas, pero sin referirse en concreto a la actual campaña. 
nacional para negociar con el Estado la autodeterminación. Los cambios y los movimientos - ya que se mantenían los resultados - se producían dentro de cada bloque político. Nada extraño, por otro lado, en que muchos ciudadanos cambiasen el voto según el tipo de elecciones. «Su identidad nacional es más porosa y menos rígida que la de los dirigentes de los partidos. La pluralidad no consiste sólo en la cohabitación de los que tienen ideologías y encuadramientos políticos diferentes, sino también en la presencia de personas que tienen afectos compartidos a los dos lados de la raya nacional» ${ }^{106}$.

Una segunda cuestión fue la viabilidad de un plan vasco de pensiones. Santiago González escribió que el informe sobre un sistema propio vasco de pensiones encargado por el Gobierno Vasco era innecesario por dos razones: primero, porque sus conclusiones ya se conocían dado el carácter deficitario del sistema en el País Vasco; y segundo, porque se había mantenido oculto en un cajón desde hacía un año, ya que, como otros informes, no interesaba. Sobre el tema se había manifestado Joseba Azcarraga con un comentario típico de un nacionalismo puro y radical: «Estamos dispuestos a asumir aquello que incluso puede ser negativo para la comunidad autónoma, aunque dudo de que esto lo sea». Por el contrario, la portavoz del Gobierno, defendía la solidaridad en todo el Estado y la caja única, aunque el autor sugería la certeza de que no era ésa la idea entre los miembros del PNV y afirmaba que informes como el aludido el Gobierno Vasco tenía muchos sobre muchos temas. «Dirá usted - añadía- que eso se parece mucho al mal uso del dinero público. Craso error. Es el don de la ubicuidad: están en todas las posiciones al mismo tiempo»107. Y, ante la acusación de «irresponsable instrumentalización electoral» por parte de populares y socialistas de las conclusiones negativas del estudio en cuestión, Marco Gardoqui opinó que, si de verdad el Gobierno Vasco quería tranquilizar a la gente, tenía que proporcionar datos que enmendasen o desmintiesen las conclusiones del estudio encargado por él. La viabilidad de las pensiones, añadía, necesitaba una correcta administración, pero, sobre todo, fomentar la natalidad, atraer emigrantes, crear mucho empleo o, de lo contrario, aumentar las cotizaciones o disminuir las prestaciones. De ahí que el articulista se preguntara quién era el irresponsable ${ }^{108}$.

Una tercera cuestión fue el homenaje a José Antonio Aguirre, que, según Florencio Domínguez, el PNV había convertido en un acto de partido, cuando bien podía haber sido un acto institucional. Hubo dos interpretaciones de su figura. Ardanza destacó la capacidad de Aguirre de buscar

106 El Correo 29-2-04, «La raya nacional», Florencio Domínguez.

107 El Correo 3-3-04 (22), «Informe innecesario», Santiago González.

108 El Correo 11-3-04 (39), «Irresponsable sí, pero ¿quién?», Ignacio Marco-Gardoqui. 
entendimientos plurales y su respeto por la legalidad. En cambio, Ibarretxe presentó la política de Aguirre y la suya propia como dos líneas paralelas, es decir, como si aquélla fuera un precedente de su estrategia con el «plan»: sacarlo adelante, llevarlo a Madrid, convocar una consulta y desafiar a cuantos se opongan a su proyecto. El autor interpretaba que la actuación de Aguirre no se acomodaba a esta estrategia, ya que después del fracaso del Estatuto de Estella Aguirre no retó a las instituciones republicanas, sino todo lo contrario. «Aguirre rectificó la estrategia de su partido: renunció a aquel proyecto estatutario, rompió con aquellos aliados y buscó un consenso posibilista con el PSOE de Indalecio Prieto que hizo posible la aprobación de la primera autonomía vasca basada en el acatamiento de la legalidad republicana ${ }^{109} \gg$.

Los últimos comentarios al nacionalismo tienen en común que trascienden el tiempo de la campaña y se pueden considerar, como ya he dicho,

109 El Correo 8-3-04 (19), «Centenario de Aguirre», Florencio Domínguez. En p. 20 Xabier Gurrutxaga escribe «La verdad y los votos», comentando la afirmación de Mayor Oreja «no busco votos, busco esencialmente la verdad», para concluir lo contrario que el candidato popular. Hubo algunos otros comentarios que destacaron las lagunas de la campaña tanto temáticas como personales. Las primeras eran el poco relieve que tuvo la política exterior y la ausencia, prácticamente total, de la inmigración. El silencio del PP, decía Carlos Gómez Gil, se producía después de cuatro años de acusar a la inmigración de males tales como la delincuencia, inseguridad ciudadana, deterioro de los servicios sociales, colapso de la sanidad pública y de la educación e, incluso, del aumento de terrorismo. La inmigración - a la que ni siquiera se le permitía votar - había sido para el PP el chivo expiatorio de las insuficiencias de su gobierno y la mano de obra barata y abundante del crecimiento económico español. La herencia del gobierno en materia de inmigración era lamentable. España se había convertido en una fábrica de inmigrantes irregulares. El PP prometía mantener su política de extranjería, es decir, «aumentar la vulnerabilidad social de los inmigrantes y seguir generando un discurso de racismo social latente». El resto de los partidos no generaba, salvo IU, una política muy diferente a la del PP. Xavier Gurrutxaga, después de la denuncia del olvido de la inmigración y de la defensa de una generosa concesión de los derechos sociales y políticos a los inmigrantes, escribió: «Ahora que se habla del peligro de los nacionalismos étnicos sería bueno que algunos reflexionaran sobre la superioridad jurídica que la Constitución española otorga a la nacionalidad sobre la ciudadanía». No se entiende cómo Kepa Aulestia pudo escribir que la «referencia vasca» estuvo casi ausente de la campaña electoral. Es verdad que no se discutió el plan Ibarretxe, ni ningún partido nacionalista tuvo sitio relevante en una campaña dominada por los dos grandes partidos, pero el nacionalismo y, especialmente, el nacionalismo vasco ocupó la parte más gruesa de las tres campañas, la de los partidos, la de los editoriales y la de los comentaristas. Ver, también, El Correo 29-2-04 (43), «La diplomacia en campaña», Carlos Taibo; 7-3-04 (28), «Silencios de campaña», José Luis Zubizarreta, artículo que pretendía explicar las razones de la ausencia del tema de la inmigración; 9-3-04 (32), «El Voto de la inmigración», Carlos Gómez Gil; 10-3-04 (20), «Ritmo», Kepa Aulestia; en la p. 2 del mismo día «Ayudas fijas», un comentario de Santiago González que critica la escasa política del Gobierno Vasco, donde cabía decir lo contrario del texto bíblico, que la mies es poca y los operarios del Gobierno Vasco muchos; 10-3-04 (22), «Inmigración y elecciones», Xavier Gurrutxaga. 
análisis de fondo del nacionalismo, cuestión que no quita un ápice a su importancia electoral. El primero analiza la política del Gobierno Vasco en cuanto instrumento de simulación y disimulación de la sociedad vasca. El segundo, el fanatismo como problema de la sociedad vasca. Y el tercero plantea la integración de los nacionalismos en el Estado.

La simulación y la disimulación de la realidad vasca, «simular lo que no está pasando y disimular lo que en verdad nos ocurre», eran dos habilidades del Gobierno Vasco, discípulo aventajado de las recomendaciones de Maquiavelo. La prueba última de semejante condición era la «Campaña de sensibilización por la paz y la libertad», verdadera campaña de maquillaje de la realidad vasca. En su presentación, el lehendakari manifestó su voluntad de actuar ante las amenazas a las víctimas con «permisividad cero». Pero, según el autor - Aurelio Arteta-, se olvidó de su recurso de inconstitucionalidad contra la ley de partidos, de la defensa que hizo de Batasuna, como si ésta no amenazara o asustara, y de la negativa de la mayoría de gobierno del Parlamento de disolver el grupo de «honestos parlamentarios» de Batasuna. Un segundo aspecto lo constituía la reducción o simplificación de la realidad vasca al terror o a su amenaza, olvidando el insidioso etnicismo que dividía a la sociedad vasca en dos partes. La primera en silenciar la voz crítica no era ETA, sino «una presión entre oficial y ambiental sofocante, la perversión ordinaria de bastantes sentimientos morales, la estúpida sumisión a lo juvenilmente correcto». Una tercera cuestión que llegaba a la desvergüenza consistía en utilizar «mecanismos de equiparación de lo desigual para así falsear los riesgos, devaluar a las víctimas o repartir sin distingos las responsabilidades políticas». Esto ocurría al decir «cuando ETA amenaza a un representante político... nos amenaza a todos y a todas» o «cuando silencian una voz, nos callan a todos»o cuando el Gobierno Vasco pedía que el intento terrorista no sellara «tus labios». ¿Acaso - se preguntaba el autor - «nos está invitando a reflexionar en voz alta sobre la imposible pretensión democrática del etnicismo o el sin fundamento de la secesión de Euskadi?». La grosera indiscriminación de todos los espectadores que hacía el Gobierno Vasco llegaba a la infamia al proclamar que los ciudadanos vascos maquillaban la persecución de las otras (supongo que personas) «por igual y con una falta parecida». La transigencia institucional favorecía los nacionalistas, mientras que a los contrarios les tocaba padecerla. Por último, la campaña a la que se refería el comentario malentendía la naturaleza de la democracia, ya que el derecho a la vida no era el fundamento de la democracia, sino de la convivencia civil; no era el requisito y la conquista de la democracia, sino el punto de partida de la política. El primer pilar de la democracia era el respeto a la dignidad de las personas, de donde se deducía la igualdad de los individuos como ciudadanos y únicos sujetos de derechos. «¿Pero no arranca el 
plan Ibarretxe justamente de la premisa contraria, de una hipotética nación étnica dotada de derechos? ¿Y no propone como punto de llegada una sociedad de individuos desiguales?» ${ }^{110}$. El esfuerzo de maquillar el rostro de Euskadi pretendía ciertos objetivos finales, más allá de adecentar un rostro para poder mirarle. El primero era el de concentrar toda la culpa de lo que sufre la sociedad vasca en la banda terrorista haciendo así innecesaria la pregunta sobre la complicidad de los nacionalistas, gobernantes o radicales con la banda armada en cuestiones como el Pacto de Estella o las políticas conjuntas de construcción nacional. El segundo era la inicua difuminación de la responsabilidad político-moral entre todos los ciudadanos, como si no hubiera ninguna diferencia entre las conductas seguidas por éstos. Y el último objetivo era el ocultamiento de la responsabilidad, incomparablemente mayor, de los partidos nacionalistas instalados en el Gobierno. El autor del artículo defendía que estos objetivos estaban expresamente enunciadas en el discurso de Ibarretxe de inauguración de la campaña. «El nacionalismo vasco, en definitiva, ha de saber que no vale jugar con dos barajas, proteger a los amenazados y a la vez amparar a ésos que hoy mismo volverían gustosamente a amenazarlos. Que no tiene legitimidad alguna para arrogarse la defensa de las víctimas cruentas de hoy quien está dispuesto a crear numerosas víctimas incruentas mañana. Pues no sólo se violan los derechos humanos cuando es ETA la que acosa, sino también - otros derechos cuando un proyecto político de secesión pretende que la mitad menos uno de los vascos quede a merced de la mitad más uno. Entonces es el propio Gobierno quien amenaza a sus ciudadanos» ${ }^{111}$.

$\mathrm{Ni}$ rechazo absoluto del cambio ni indiferencia o oportunismo ante cualquier cambio, sino pensamiento crítico. Ni tiranía del pasado, ni tiranía de lo nuevo, sino ejercicio de la libertad y de la razón ante la necesidad del cambio. Desde esta premisa, Rafael Aguirre abordaba el fanatismo como concepto y como problema de la sociedad vasca, aquejada de una notable crisis moral e ideológica. En cuanto concepto, el fanatismo es empecinamiento y resistencia absoluta al cambio. El fanático sustituye las ideas por las creencias y la realidad compleja por la evidencia visionaria. Rechaza el diálogo, entendido como intercambio de razones, por el adoctrinamiento e interpreta la crítica como demonización de su persona. Su fundamento es la creencia en la posesión de la verdad y bondad absoluta. El fanatismo social y político obliga a una dinámica impositiva, «que no repara en medios para extender su visión de la realidad y conseguir sus objetivos». Frente al fanatismo no hay más actitud que hacerle frente y resistirle de forma rotunda sin caer en la tentación de ceder o llegar a acuerdos, ya que éstos le confir-

110 El Correo 3-3-04 (28), «Campaña de maquillaje (I)», Aurelio Arteta.

111 El Correo 5-3-04 (34), «Campaña de maquillaje» (y II), Aurelio Arteta. 
man en su estrategia, en último término violenta. En cuanto componente de la realidad vasca, el fanatismo era la raíz de los problemas de la sociedad vasca. Se trataba de una ideología fanática, que, sin nombrarla, era la del nacionalismo, que alteraba la visión de la realidad e interpretaba la historia de manera mítica y falsa. Era la raíz de los problemas que aquejaban a la sociedad vasca. «Gentes muy finas se rasgan las vestiduras y dicen sentirse atacadas en su libertad de expresión cuando, en realidad, lo que pretenden es quitársela a quienes les critican - el caso de la película de Medem-». Que personas de ideologías premodernas apoyasen en el País Vasco causas de gravísimas repercusiones sin criterio y sin debate comprometiéndose «en una irresponsable estrategia de rupturismo» era algo notable para el autor. El escrito llamaba a la prudencia de enfrentarse al fanatismo nacionalista sin caer en el mismo error. Resistir y denunciar al fanatismo, pero sin perder «la capacidad de cambiar sabiamente» ${ }^{112}$.

En un artículo de fondo Juan José Solozábal trató el problema de la integración de los nacionalismos en el Estado autonómico. La dificultad mayor de la reforma autonómica era de naturaleza política y consistía en la capacidad de integrar a los nacionalismos territoriales. Pero la cuestión no dependía sólo del Estado, sino de las disposición de los nacionalismos para su conjunción. La creencia durante el período constituyente de que el sistema autonómico - preferentemente se dijo esto del federalismo - era la respuesta política al nacionalismo y que de manera casi infalible iba a conseguir la integración se había demostrado ingenua. El federalismo es cultura de transacción, de pacto y de presentación jurídica de los problemas y es lo contrario del nacionalismo de la autodeterminación y del espacio político exclusivo. Así lo demuestran los Estados federales exitosos que no tienen nada que ver con los nacionalismos y que «resisten malamente las tensiones de las nacionalidades». Pero nada de esto debía impedir el intento de acomodar a los nacionalismos en el Estado o la aceptación del pluralismo por parte del Estado central en su composición y funcionamiento o la solicitud de lealtad institucional a los nacionalismos. Ahora bien, antes de cualquier acuerdo entre Estado y autonomías gobernadas por nacionalistas era necesario reanudar el diálogo institucional y renunciar por ambas partes a abusos retóricos. El Gobierno central debía aceptar las sinceridad del compromiso democrático del nacionalismo y su capacidad de modernidad y eficiencia, «que rebajan considerablemente sus perfiles etnicistas» y los nacionalismos debían saber que no están enfrente del clásico nacionalismo español, sino ante un tipo de constitucionalismo integrador, flexible y plural que garantiza la defensa de su identidad colectiva. Si se realizara esta

112 El Correo 4-3-2004 (30), «El arte de saber cambiar», Rafael Aguirre. 
aproximación, ambas partes deberían intercambiar algunas concesiones. El Estado debería reconocer la legitimidad de su cuestionamiento, pues no se trata de una estructura natural y eterna. «Obviamente no estamos hablando de un derecho de secesión, por parte de una fracción de la comunidad, absoluto ni ejercible sin garantías de seriedad y sin atenerse a escrupulosas reglas constitucionales de procedimiento. La admisión de la autodeterminación, por lo que vemos más como pretensión que como auténtico derecho, no es el único reconocimiento que el Estado debe a los nacionalismos territoriales, sin cuya contribución difícilmente se habría producido la constitución y consolidación del sistema autonómico». Una vez aceptada por el Estado la legitimidad de su cuestionamiento, los nacionalismos podrían verse inducidos a posponer el ejercicio de su pretensiones secesionistas e incluso a abandonar las mismas, si la reforma del Estado lo hiciese aconsejable. Pero lo más exigible a los nacionalismos sería que sus propuestas de reforma institucional respetaran los requisitos procesales del orden constitucional y se llevaran a cabo desde una base nacional o general más que nacionalista. Lo primero impediría la autorruptura constitucional y la reforma unilateral del Estatuto - la consulta sería absolutamente improcedente al margen del derecho - y lo segundo evitaría alterar el significado del Estatuto como norma de autogobieno de todos los ciudadanos ${ }^{113}$.

En relación con los socialistas, los comentarios destacaron la difícil, pero no imposible, tarea de que ganase Zapatero; la imposibilidad de que

113 El Correo 7-3-04 (40 y 41), «Nacionalismos e integración», Juan José Solozábal. No comparto buena parte del artículo por varias razones: el compromiso democrático del nacionalismo no distingue entre la convicción democrática y la necesidad democrática; su capacidad de modernidad y eficiencia no ha probado un efecto positivo en rebajar el etnicismo vasco; la aceptación de la legitimidad del cuestionamiento del Estado con la afirmación de que no es una estructura natural y eterna es una evidencia que no prueba nada, porque supondría legitimar cualquier cambio por el mero hecho de que nada es eterno; identifica a los nacionalismos con el territorio, como si en el territorio vasco no hubiese más que nacionalistas, identificando así nacionalista con vasco; no reconoce el derecho absoluto de secesión, pero sí la autodeterminación, que no sería tal si no se pudiese utilizar para la separación; muestra una confianza ingenua (por no creer en el fanatismo del nacionalismo, en concreto, del vasco) en que los nacionalismos podrían renunciar o posponer la autodeterminación, si les fuera bien con las reformas del Estado; el planteamiento de la autodeterminación por los nacionalistas como una pretensión, más que como un derecho, podía ser una estrategia temporal y, a la vez, un objetivo a largo plazo; el nacionalismo vasco no apoyó la Constitución, y el ejercicio del poder desde ella y el Estatuto ha sido desleal; es una contradicción pensar en una base nacional o general, no sólo de los nacionalistas, para sus propuestas radicales, ya que éstas dividen en dos a la sociedad vasca; el plan Ibarretxe no respetaba los requisitos procesales del orden constitucional; es contradictorio presentar al federalismo como cultura del pacto y como algo absolutamente contrario al nacionalismo de la autodeterminación, y luego defender la autodeterminación para el nacionalismo vasco, sin especificar qué forma política saldría de semejante planteamiento. 
obtuviera votos útiles en la izquierda y en el centro, dada la situación de inferioridad en que se encontraba el PSOE, aunque la opción real por los de la izquierda le restaba votos en el centro; los gestos del PSE hacia el nacionalismo, que, sin abandonar el rechazo del Plan Ibarretxe y alejándose cada vez más del PP, buscaba el acercamiento al PNV, cosa que no gustaba a ETA; la estrategia, común con el PP, de derrotar a ETA policialmente, que había sustituido a la negociación defendida hacía diez años, estrategia basada en los fracasos alcanzados al tratar de convencer a ETA de que abandonara las armas; los intentos de Zapatero por desmarcarse de Carod Rovira y dar una imagen de moderación; la opinión de que la doble campaña de Zapatero y las impertinencias de Bono y Rodríguez Ibarra no parecían perjudicar al candidato socialista; la defensa de los socialistas vascos de la recuperación del diálogo con los nacionalistas para lograr, de paso, algún diputado más; y la identificación de la campaña de Zapatero con un «bostezo inexorable».

La crítica a los socialistas incluyó su voluntad de pasar de puntillas por la política vasca; la pretensión de un debate Zapatero-Rajoy que sonaba a autosuficiencia y vodevil, cuando el debate debía hacerse dentro del propio socialismo para salir de la ambigüedad, que creaban el proyecto nacionalista y dependiente de Carod del presidente de la Generalidad o el de la firmeza democrática de Bono; la asunción de los socialistas vascos de los mensajes del PNV de otras campañas contra el Partido Popular - incluso de las acusaciones nacionalistas anteriormente dirigidas contra populares y socialistas -, que permitían la pregunta de si no se estaría dando un cruce de intereses entre el PNV de Imaz y el PSE; la exigencia de explicaciones a Zapatero, con ocasión de las detenciones de Cuenca, por su relación con Carod y la crítica de que sólo parecía que se alegraban los del PP y las víctimas del terrorismo; la calificación de mentira que hizo Rodríguez Ibarra de estas mismas detenciones; la devaluación que suponía para el discurso de Zapatero el anuncio de las encuestas del triunfo socialista por mayoría absoluta en Andalucía, cuando se sabía el uso que habían dado los socialistas a su poder omnímodo en dicha comunidad autónoma; o las preguntas dirigidas a Maragall sobre su criterio acerca de las agresiones y suspensiones de actos realizadas en la Universidad de Barcelona contra las personas de Savater, Jon Juaristi y otros, que no pudieron actuar en lugares donde previamente habían intervenido Arnaldo Otegi o Pepe Rey.

Para concluir conviene añadir dos cuestiones más. La primera es la crítica a determinadas actuaciones de intelectuales, como la de la catedrática de la UPV y candidata a diputado por el PSOE, Arantza Mendizabal, que había manifestado sobre el «lío vasco»: «La propaganda del PP ha convertido en incompatibles dos conceptos: Euskadi y España (...) El PP ha radicalizado al nacionalismo hasta situarlo en el pacto de Lizarra o en el Plan Ibarretxe», 
que permitió al articulista escribir: «Menos mal que no es catedrática de Historia Contemporánea. No estaría de más que alguien de su partido, más versado, le explicara que el PNV se fue a Lizarra él solito por su propio pie, en la misma legislatura en la que apoyaba a Aznar en Madrid y que, al iniciar su negociación con ETA, en el verano del 98, todavía era socio del PSEEE en el Gobierno de Vitoria. Ya en este plan, Pastor ha acusado al PP de ser «corresponsable» de la violencia contra las mujeres. Debe ser la vertiginosa afición de los deudos del ahorcado a mencionar la soga» ${ }^{114}$.

Y la segunda se refiere a la ausencia de personas en la campaña. Florencio Domínguez destacó la de la militante socialista Maite Pagazaurtundua para denunciar la crítica dura que le había dirigido el cabeza de lista del PNV por Guipúzcoa acusándole de estar en guerra con los nacionalistas, de buscar la confrontación y el enfrentamiento y de poner en peligro «la convivencia ciudadana en beneficio propio». El articulista comentó: «Las víctimas convertidas en verdugos. Mientras, su partido, el PSE-EE, guarda silencio ante imputaciones tan desafortunadas contra uno de sus cargos públicos. Otra gran ausencia» ${ }^{115}$.

En el caso del Partido Popular, los comentarios destacaron: su pretensión de obtener la mayoría absoluta para mantener el modelo de Estado y su política con los nacionalismos, que, de ocurrir, pondría al plan Ibarretxe en una difícil situación; la utilización, en contra de los socialistas, de las propuestas de Carod Rovira de formar un gobierno de concentración anti PP; el pronóstico de que su mayoría absoluta se jugaría en la provincia de Barcelona; la convicción de que cada kilo de explosivo interceptado a los terroristas de ETA valía más electoralmente que una tonelada de edificantes palabras de Rodríguez Zapatero; el uso de la confrontación - tanto de populares como de socialistas vascos - acotando su territorio en busca del voto sin dejar espacio para la colaboración; la idea de radicalizar en la segunda parte de la campaña su discurso del peligro para la continuidad de España sin una mayoría absoluta popular (lo que constituía una mala apreciación, ya que tal discurso se había producido desde el principio); la coincidencia con los socialistas en que la estrategia antiterrorista pasaba por la derrota policial de ETA; el uso por parte de Rajoy del catecismo de «Ripaldaznar» y la tesis de que la derrota de Rajoy supondría la debacle nacional; la interpretación de que la doble campaña popular, la de Rajoy y la de Aznar, podría perjudicar al candidato popular, con lo que, gracias a Aznar, la mayoría absoluta se hacía una quimera; los cambios (interpretación más que dudosa) en la estrategia electoral ante tal posibilidad y la ob-

114 El Correo 11-3-04 (23), «Campaña intelectual», Santiago González.

115 El Correo 10-3-04 (21), «Ausencias», Florencio Domínguez. 
servación de que, en este supuesto, la necesidad de pactar con algún partido «antipatria» habría abierto en el PP «la espita del pánico».

Además, en los artículos apareció la crítica expresa a los intentos del Partido Popular, en concreto, de Mayor Oreja, de catalanizar la campaña (en realidad, se trataba de polarizar la campaña socialista en torno a la unión con los nacionalismos) y a las pretensiones, muy arriesgadas para los populares, de cuestionar el compromiso constitucional de los socialistas, ya que éstos se encontraban tan amenazados por el terrorismo como los mismos populares. La utilización de la violencia de ETA con fines partidistas, manifestada en los ataques al partido socialista con motivo de la entrevista de Carod con ETA, no buscaría otra cosa que obligar a los socialistas a estar sometidos al PP.

La censura al Partido Popular subió de tono al comentar la perspectiva de un PP vencedor sin mayoría absoluta. Se había pasado de una precampaña en la que Zapatero hacía el papel de Nazareno a un campaña en la que «las cagadas (sic) empezaban masivamente a caer del lado contrario. Trillo y sus cenas demasiado generosas, Acebes y Michavilla y sus clases de geografía ETARRA, Aznar y su problema con los muertos insepultos del Yak-42 (fino Pepino al subrayar la presencia de una de las viudas en el mitin donostiarra del otro día), Teófila y el gastador de la Zona Franca de Cádiz (¿pero los ladrones no eran los otros?), la burda apropiación de las víctimas del terrorismo...». Las encuestas habían acrecentado, además, la arrogancia, la crispación y el espesamiento de Rajoy, como determinadas manifestaciones de Aznar habían demostrado su presunción ${ }^{116}$.

La pretensión del delegado del Gobierno en el País Vasco, Carlos Urquijo, de que se quitara de los libros de texto el término Euskal Herria que acompañaba a un mapa del País Vasco fue criticada por Pello Salaburu en un buen comentario, en el que defendía que no se trataba de un término nacionalista, aunque la izquierda abertzale lo había manchado, como ocurría con todo lo que tocaba. El término no era ni político, ni sociológico, ni cultural ni económico, aunque pudiera tener un poco de todo ello. Era un término semejante al de Laponia. La cuestión resultaba tan absurda que se esperaba que acabara en la papelera. Sin embargo (sumándose a la crítica general contra el PP), el artículo añadía que «si siguiendo el curso del río

116 El Correo 9-3-04 (28), «¿Pasa algo?», Lorenzo Silva. El comentario despectivo hacia Aznar lo había hecho José Luis Zubizarreta a propósito de una palabras de Aznar con las que se había comparado con Carlos $\mathrm{V}$ y con el patricio romano Cincinato, por aquello de que los tres renunciaron al poder voluntariamente después de prestar grandes servicios. «Tamaña presunción - concluía el escritor - haría llorar si no estuviéramos en campaña. ¿Pobre Cincinato?» (El comentario que resaltaba el posible engreimiento era correcto, pero resultaba impertinente por no reconocer ningún valor en semejante gesto en un país en el que muy difícilmente alguien se va del poder a no ser que lo echen). 
franquista acaba en las manos de algún juez inquisidor, y el juez acaba dictaminando lo que cualquier mentalidad franquista actual puede acabar dictaminando en esta ceremonia de la confusión político-judicial, el término "Eskal Herria" terminará adquiriendo para todos, no ya para algunos, un sesgo político que nunca ha tenido. A ello habrá contribuido el delegado del Gobierno» ${ }^{117}$.

Manuel Alcaraz Ramos denunció el apoyo que los obispos a través de sus documentos daban al Partido Popular. Los obispos animaban a un voto conservador. La razón estaba en que la derecha española delegaba en la Iglesia los asuntos de la conciencia y de la «entrepierna» (homosexualidad, parejas de hecho, investigaciones con células madre) y subvencionaba fuertemente con los presupuestos del Estado el ejercicio de la caridad, el «ungüento que recubre los sarpullidos que deja el neoliberalismo en el cuerpo social». Esto repetía la práctica que la derecha española había ejercitado históricamente, la de delegar en la Iglesia, renunciando a definir a una ética autónoma, las funciones del adoctrinamiento cultural: resignación como ideología de fondo en las relaciones sociales, antimodernismo «en las modalidades de difusión estética y en la selección temática» y patriotismo «en la interpretación de una historia marcada por la alianza del trono con el altar» ${ }^{118}$.

Hasta la matanza del 11-M, ETA no ocupó mucho espacio en los comentarios. Y cuando lo hizo, fue, más bien en relación con los partidos, especialmente los nacionalistas, por su utilización en la demanda del voto, por su estrategia ante el terrorismo, por los éxitos contra el mismo o por el miedo a enfrentarse con ella. En un principio se escribió que los acontecimientos previos a la campaña y la posterior manifestación de Barcelona convocada por los partidos nacionalistas catalanes dejaron marcado el comienzo de la campaña con «el signo de la cruz llamada ETA». Su presencia habría alterado la normalidad de una convocatoria poniéndose por encima de los programas y de las ideas de los partidos. Pero, en seguida, se pudo escribir que lo mejor de todo era que ETA, que fue quien quiso «catalanizar» la campaña, no estaría presente a través de listas camufladas. La verdad es que ETA no mereció ningún comentario por sí misma, ni siquiera con ocasión de las detenciones de miembros de ETA en Cuenca. Los comentarios recayeron sobre los partidos ante ETA, tema que ya ha sido recogido anteriormente y sobre el que volveré al hablar de los comentarios a los asesinatos en Madrid ${ }^{119}$.

117 El Correo 11-3-04 (31), «¿Existen Euskal Herria y Laponia?», Pello Salaburu. Tonia Etxarri también criticó el criterio de Calos Urquijo.

118 El Correo 28-2-04, (36), «El voto de la Iglesia», Manuel Alcaraz Ramos.

119 Ver El Correo 27-2-04 (23), «La normalidad es una corbata», Florencio Domínguez; 28-2-04 (24), «No más ETA, por favor», José Luis Zubizarreta; 28-2-04 (28), «Sin acento catalán», Tonia Etxarri; 29-2-04 (31), «La raya nacional», Florencio Domínguez; 2-3-04 (24), «Bombas o papeletas», Xavier Gurrutxaga; El Correo 1-3-04 (18), «Con la mano en el 


\section{B) Comentarios a la tragedia del 11 de marzo}

En 33 ocasiones los comentaristas aludieron al terrorismo de ETA, al nacionalismo, a las ideologías nacionalista e integrista, a los aliados del terrorismo, a los partidos que tenían algo que ver con ETA y a los que defendían el diálogo y la negociación con la organización terrorista. Salvo alguna excepción, que puede ser considerada como cuestión técnica - la forma de realizar el atentado- todas estas referencias son condenatorias. Alguna denuncia del fanatismo religioso estuvo también presente en estos comentaristas. Trece autores manifestaron que, ante la magnitud de la tragedia y el significado del terrorismo, resultaba irrelevante el nombre de la organización terrorista responsable. Algunos de éstos insistieron en la necesidad de clarificar la responsabilidad y manifestaron su malestar por la incertidumbre creada, pero no añadieron nada sobre las posibles consecuencias distintas que se derivarían de que fuera ETA o una organización islamista la autora. Por el contrario, en 7 artículos se exigió el esclarecimiento de la responsabilidad de los autores por las muy diferentes consecuencias que tendrían en la orientación del voto - ETA favorecería al PP y Al-Qaida al PSOE por la guerra de Irak o por las investigaciones del juez Garzón sobre Al-Qaida - y por su influencia en las estrategias de lucha contra el terrorismo. No faltó quien afirmó que ningún político sería capaz de gestionar la tragedia ni a favor ni en contra. Los demás temas tratados, en número muy inferior de ocasiones, fueron la necesidad de la unidad de los partidos no sólo contra el terrorismo, sino contra las ideologías o actitudes que los respaldaban o justificaban, la conveniencia del retraso de las elecciones, la deficiente información del Gobierno, la condición de trabajadores y personas humildes de los asesinados, la miseria de la sociedad vasca, alguna censura a los medios de comunicación por su prácticamente nula investigación y la denuncia, en una sola ocasión, del fallo de los sistemas de seguridad del Estado ${ }^{120}$.

corazón», José Luis Zubizarreta; 2-3-04 (29), «Por favor», Lorenzo Silva; 3-3-04 (21), «Tan cerca de Cuenca», Tonia Etxarri; 1-3-04 (20), «Pepemanía», Santiago González.

120 Ver: El Correo 12-3-04, «Certidumbre», F.L. Chivite; (20), «Asesinos del pueblo», Juan Bas; (41), «El tren de la muerte», Florencio Domínguez; (47), «Masacre», Xavier Gurrutxaga; 13-3-04 (26), «Votar entre lágrimas», José Luis Zubizarreta; (30), «¿Quién ha sido», Kepa Aulestia; (30), «La verdad de los votos», Xavier Gurrutxaga; 14-3-04 (28), «La red», Kepa Aulestia. En el artículo «Elogio del diálogo», Antonio Papell escribió que «... el peligro que corre nuestro régimen no es tanto que se fracture cuanto que los ciudadanos nos escindamos en facciones irreconciliables. Y ese riesgo sólo se orilla y se supera por el único procedimiento intelectualmente creativo en política: la discusión cabal, hasta la síntesis y el entendimiento». En relación al problema nacionalista y, especialmente, el terrorismo de ETA, este comentario es disonante en los dos sentidos del término, más aún, en las circunstancias del 11-M. 
Más en concreto, Savater escribió que, independientemente de que ETA hubiese sido la autora de los asesinatos, había que reconocer que lo había estado buscando desde hacía meses. ETA era una organización criminal, enmarcada dentro del terrorismo internacional, y su arrinconamiento exigía en las elecciones no votar a ningún partido que tuviese algo que ver con ella ${ }^{121}$.

La primera de estas dos afirmaciones -ETA había intentado realizar un atentado de este tipo - tuvo continuidad en los comentarios. En contradicción con las declaraciones de Otegi, J.L. Zubizarreta escribió que «la magnitud de la barbarie no es razón suficiente para negar la autoría de ETA... Todos debemos ser conscientes de que, cuando de organizaciones terroristas se trata, la escalada de la barbarie es sólo cuestión de tiempo». Tampoco era razón suficiente para excluir a ETA su silencio, ya que, por ejemplo, en el atentado de la cafetería Rolando realizado por ETA, ésta nunca lo había reivindicado. No cabía invocar la presunción de inocencia para excluir a ETA, ya que las maletas de explosivos en un tren con destino a Madrid y la furgoneta interceptada en Cuenca apuntaban a una barbarie semejante. Era, por tanto, ETA la que tenía que sacar de la incertidumbre a los que pensaban en su responsabilidad ${ }^{122}$. También Rogelio Alonso pensaba que el «incremento de la letalidad» no era argumento suficiente para excluir a ETA. La hipótesis de la responsabilidad de ETA era coherente con su trayectoria, opinaba, así mismo, Pello Salaburu ${ }^{123}$.

La segunda afirmación - no votar a ningún partido que tuviese algo que ver con ETA - tuvo también continuidad de forma expresa o tácita. «La memoria de nuestros muertos - se escribió- merece un golpe de mano, un punto y final al terrorismo, en el que la impunidad de los que matan y justifican a los asesinos, o de los que se aprovechan de una estrategia equívoca y vil para favorecer sus políticas excluyentes, pase al baúl de los peores recuerdos de nuestra historia. Es momento de desterrar de sus taifas a los ayatolás de la disgregación, la diferenciación, la exclusión y la discriminación, pues se aprovechan de los beneficios de esta democracia de la que reniegan para maquinar intrigas de odio y enfrentamiento» ${ }^{124}$. Además de sentir vergüenza de que hubiese asesinos entre los vascos y considerar enferma y maldita a la sociedad vasca, Manuel Montero manifestó la necesidad de vivir por la democracia y dejarse de planes, antiplanes y dislates políticos $^{125}$.

121 El Correo 12-3-04 (28), Fernando Savater, nota sin título.

122 El Correo 12-3-04 (49), «Además de ignominia, confusión», José Luis Zubizarreta.

123 Ibídem, pp. 52 y 57.

124 El Correo 12-3-04 (33), «11 de marzo», Miguel Aranguren.

125 El Correo 12-3-04 (59), «El peor día de nuestras vidas», Manuel Montero. 
Juan-Luis Ibarra Robles, a pesar de las dudas sobre los autores y centrando la argumentación no en la identidad de los asesinos, sino en las víctimas, se preguntaba si después de la tragedia sería posible la democracia en el País Vasco. La respuesta no dependía de que los terroristas perteneciesen a ETA o a Al-Qaida. La sociedad debía resolver su dilema «decidiendo si las víctimas de hoy son o no son nuestros conciudadanos y compatriotas. Un dilema que no puede eludirse mediante el sofisma de que los asesinos no son vascos, una vez que sabemos que la violencia terrorista no requiere de rostro humano; la cuestión ahora está en saber si estamos o no dispuestos a ser consecuentes con que los asesinados hoy en Madrid son de los nuestros; porque pertenecen ya de por siempre a nuestra memoria social y política» ${ }^{126}$.

La idea de una sociedad vasca enferma, que se menciona más arriba, fue recogida posteriormente a través de una serie de testimonios, que ponían de manifiesto, por un lado, la miseria de la sociedad vasca, y, por el otro, el concepto complaciente, benigno, tolerante y, por ello, repugnante que políticos y no políticos tenían acerca de ETA. La cuestión era el cambio anímico que se estaba produciendo en el País Vasco ante la posible culpabilidad de alguna organización terrorista islámica que liberaba a ETA de la inicial responsabilidad. «Para la sociedad vasca - dijo el presidente del PNV, Imaz - saber que no ha sido ETA, dentro del horror, supondría que se nos quitase una losa de encima». El sociólogo Javier Elzo, que llegó a pedir perdón cuando se pensaba que era ETA la culpable, manifestó que «de ser cierto - pensé que ya había dado (ETA) el salto al terrorismo de masas - , la memoria histórica de los vascos se resentiría. No es fácil cargar con 200 asesinatos en nombre de tu pueblo. Por eso comprendo el alivio, quizá egoísta, como persona del País Vasco, porque si voy un poco más allá siento que los muertos eran también mis compatriotas. Además esto a las víctimas les importa tres carajos». El problema lo resumía una trabajadora al preguntar: «¿Qué van a pensar ahora de nosotros (los vascos)? ¿Cómo podremos ir a Madrid sin que se nos caiga la cara de vergüenza? ¿Seguro que no ha sido Al-Qaida?». Frente a tales manifestaciones que escondían un sentimiento de culpabilidad colectiva ante el supuesto de que ETA hubiese sido la responsable y, por ello, el atentado se hubiera cometido en nombre del pueblo vasco, Xavier Etxebarria opinaba: «Es como si pensáramos que el monstruo no está entre nosotros. Un sentimiento peligroso, porque puede implicar que nos hayamos acostumbrado a un monstruo supuestamente pequeño y que ahora nos desinteresemos de éste porque "no es de los nuestros". Todos creímos que ETA había sido capaz de ello. No bles.

126 El Correo 12-3-04 (58), «Ser demócrata después del horror», Juan Luis Ibarra Ro- 
podemos ignorar esto». Por su parte, Imanol Zubero dijo: «Es un horror. Qué pronto estamos olvidando esa rabia y rechazo que sentíamos el jueves contra ETA... Entre todos hemos alimentado el monstruo. No vale decir que no hemos sido nosotros. A lo peor, dentro de poco, sí lo somos». Quizá lo mejor de todo lo manifestó el psiquiatra Miguel Gutiérrez: «sentir alivio porque no haya sido ETA es el síntoma de una sociedad enferma, que carece de sustrato ético» ${ }^{127}$.

Andrés Montero Gómez consideró que la atribución a ETA de los asesinatos de Madrid no era un error grande, «al menos en el sustrato básico del fenómeno», ya que «lo político en ETA o lo tortuosamente religioso en Al-Kaida no son más que instrumentaciones para justificar asesinatos... La coincidencia o no de ETA con postulados independentistas responde al mismo oportunismo criminal...» Partidos políticos como el PNV o personas como Carod Rovira habían alimentado ese «desvarío» creado por ETA. La total criminalización de ETA tenía que ser obra de un proceso de despolitización, en el que «deberían confluir el tratamiento de ETA como fenómeno criminal, y no como un síntoma de ningún conflicto histórico en Euskadi, y la inquebrantable unidad de la política democrática». Para el autor carecía de explicación que el PNV fuese ambiguo con respecto a ETA y a su entramado por potenciar, así, su autonomismo secesionista. Hacía falta un pacto común que diera lugar a un enfrentamiento claro contra la amenaza criminal. «Las elecciones de hoy, concluía, tienen que servir para que los ciudadanos voten por un gobierno y un parlamento y para que este ejecutivo, inmediatamente después de constituirse, convoque al resto de partidos, sin exclusión, a un pacto de Estado integral frente al terrorismo, un pacto político para despolitizar y afrontarlo policial, judicial y criminológicamente» ${ }^{128}$.

La crítica al nacionalismo abarcó la interpretación de Ibarretxe de que los asesinos de ETA no eran vascos, sino alimañas. «Si se confirmara la autoría de ETA, habría que convenir que sí son vascos... No parece pertinente discutir la condición de vasco a los que han llegado tantas veces hasta el asesinato para afirmar sus señas de identidad, para subrayar su condición de vascos... En estos momentos hay dos hipótesis probables: que sean seres humanos, vascos y nacionalistas o que sean seres humanos, árabes e integristas. Es evidente también que en ambos casos son asesinos» ${ }^{129}$.

La tardanza de ETB en informar del atentado - tres horas después - y su tendenciosa información permitieron que Lucía Mtnez. Odriozola escri-

127 El Correo 13-3-04 (24 y 25), «Entre el dolor y el alivio», Iñaki Esteban.

128 El Correo 14-3-04 (40), «Despolitizar el terrorismo», Andrés Montero Gómez.

129 El Correo 12-3-04 (45), «Sin palabras», Santiago González. 
biera: «Usted y yo teníamos alguna sospecha de lo tendenciosa que puede llegar a ser la cadena pública (ETB). Ayer, que las víctimas se contaban por centenas, producía un dolor desgarrador, una imperiosa sensación de que está en manos de gentes que narran la realidad a través de una lente muy empañada. Las televisiones públicas francesa y británica viven momento de dimisiones. Alguien debería tomar ejemplo, y miro hacia Iurreta» ${ }^{130}$.

Para Joseba Arregi era necesaria la unidad para defender la democracia, la libertad individual, el Estado de Derecho y el pluralismo, porque eran estos valores los que negaba el odio tanto de Al-Qaida como de ETA. El comentarista, que no entraba en la cuestión de quiénes eran los autores ni en sus consecuencias electorales, unificaba el tratamiento de los mismos al escribir que unos y otros «pretenden situaciones uniformes, siendo ellos quienes definen la norma de la uniformidad. Desprecian la libertad. Desprecian al individuo. No existe más que lo colectivo, sea el colectivo de creyentes, sea el colectivo de pertenecientes a lo que ellos denominan pueblo. Y para los colectivos la existencia individual siempre es disponible, sin importancia, una nimiedad comparada con la existencia y la vida del colectivo» ${ }^{131}$.

Hubo quien se sintió generoso con las explicaciones del ministro Acebes, aunque reconociese, entre otras razones, los «inevitables intereses partidistas» que había en sus informaciones, pero censuró firmemente el comportamiento de la abrumadora mayoría de los medios de comunicación que no intentaron examinar los hechos ocurridos y no se centraron en el tema de la autoría de los atentados como estaba ocurriendo en las televisiones extranjeras. Ni siquiera las dudas del Ministerio del Interior hicieron cambiar de comportamiento. La determinación de la autoría afectaba a la

130 El Correo 12-3-04 (48), «Reacción tardía», Lucía Mtnez. Odriozola. Santiago González criticó el empeño con que ETB defendió la autoría de Al-Qaida mostrando la portada del campeón de los tabloides, Daily Mirror. No entendía la causa de ello, porque el horror era el mismo en ambas hipótesis, aunque era más inquietante para el futuro la responsabilidad del terrorismo islámico. A ETA se sabía combatirla. A Al-Qaida, no. «¿Habrá algún interés electoral en ello? No lo creo. Como sabemos todos los que vemos ETB, el electoralismo es un vicio que practica en solitario el Partido Popular. Uno de los invitados de la televisión autonómica lo explicaba ayer: «Sentí alivio porque no han sido compatriotas míos». Un día más tarde ya no éramos madrileños y parecía más relevante el hecho de compartir el gentilicio con "nuestros" terroristas que el sufrimiento de las víctimas. Seamos madrileños hoy también» (El Correo 13-3-04, p. 24, «Ser madrileños». Ver, también, el artículo de Santiago González, «El giraldarra» - El Correo 7-3-04 (28), ya citado anteriormente-. Margarita Rivière en su art. «Iban contra todos», p. 35, dice cosas como que los ciudadanos normales quieren ejercer su libertad y los derechos «colectivos» o que Barcelona reaccionó contra el horror y, también, otros muchos sitios más «en esa Cataluña injustamente tratada en la campaña electoral».

${ }^{131}$ El Correo 13-3-04 (33), «En defensa propia», Joseba Arregi. 
retórica y a los intereses electorales y la invocación de la españolidad de las víctimas tenía un significado muy diferente según el autor, así como la manifestación en defensa de la Constitución perdía su sentido si era un grupo islamista. Había que invocar, no para justificar, sino para explicar en el caso del islamismo, las políticas practicadas por las potencias occidentales sobre Oriente Próximo, cuyo último episodio sería la «agresión criminal» de la guerra de Irak «con el franco beneplácito del Gobierno español». Pero, «la demanda de que el Gobierno español - el que fuere- revise drásticamente sus actitudes en relación con Irak, nada tiene que ver con los atentados de Madrid y sus posibles autores: es anterior a aquéllos y se justifica por sí sola» ${ }^{132}$.

En un breve comentario José Ignacio Calleja consideró vital saber quién era el autor, «no para aminorar la gravedad al crimen, sino para saber de la causa, del tratamiento y, en lo posible, de la curación... Si además está en juego el resultado de unas elecciones generales y el juicio de toda la política internacional de España, más aún, de casi toda la trayectoria política de Aznar, la urgencia es todavía mayor... Si alguien cayera en la tentación de hurtarnos a tiempo alguna información, falsearía el resultado de unas elecciones democráticas...» ${ }^{133}$.

Este juicio que hacía depender la falsedad de unas lecciones, el resultado electoral y la valoración de la política internacional de Aznar de un solo elemento, la ocultación o no de la responsabilidad del atentado, como si fuera la única causa posible de semejantes consecuencias, contrastaba con los comentarios de Tonia Etxarri, que consideraba «desalmado»hacer las cuentas sobre quién saldría beneficiado de que fuera ETA o un grupo islamista. «Y algunos líderes de opinión nos quieren ayudar a pensar. Y se dedican a hacer una equivalencia entre la influencia del nacionalismo en el terrorismo de ETA con la política exterior del Gobierno del PP en el terrorismo de Al-Qaida. ¿Captan la sutileza? Sin citar, por cierto, el papel de los muyaidines y fanáticos religiosos que desde los minaretes de las mezquitas y escuelas coránicas lanzan mensajes inflamados de Guerra Santa contra Occidente. De la misma forma que han resultado incendiarios, tantas veces en Euskadi, los discursos contra la España (fascista), contra la Constitución o contra «la bota de Madrid». Pero los ciudadanos de a pie saben que el atentado no lo ha provocado ni el PP, ni el PSOE, ni ERC. Han sentido un «mazazo» del terrorismo que pretende bloquear su voluntad con el miedo y coartarle su libertad de pensamiento» ${ }^{134}$.

132 El Correo 13-3-04 (34) Todólogos», Carlos Taibo.

133 El Correo 13-3-04 (17), «Averiguar el autor», José Ignacio Calleja.

134 El Correo 13-3-04 (20), «Cálculos diabólicos», Tonia Etxarri. «Algo habremos avanzado - escribía, creo que ingenuamente, José María Calleja - si después de la masacre de 


\section{Conclusiones}

El sistema de creencias del nacionalismo étnico es por su fundamentalismo, desde el punto de vista ideológico, un reto permanente al Estado constitucional; más aún, en el caso de la violencia terrorista de ETA. En este sentido, la situación, la campaña y el futuro anunciado por el PNV y EA en marzo de 2004 eran un desafío a los poderes constituidos. Ahora bien, esto no era una novedad. El PNV, desde las primeras elecciones de 1977 - y desde su fundación - , había defendido con toda claridad que su objetivo era crear el Estado vasco, étnicamente concebido, cuyo fundamento de legitimidad no era más que la ideología nacionalista. Pero en las elecciones de 2004 el reto al Estado se había extendido al campo de la estrategia y tenía fecha y calendario de aplicación: la siguiente legislatura. La ideología se iba a llevar a la práctica. Es esta estrategia la que se entendió como desafío en el sentido de competir, rivalizar mediante una lucha frontal contra el Estado, lucha que se anunció como conculcación del Derecho, y el Estado es, ante todo, ordenamiento jurídico. No cabe olvidar, por otra parte, que, más allá de las intenciones y de las palabras, el enfrentamiento al Estado tenía entre nacionalistas un gran atractivo electoral. Era así o pretendía ser, también, un reclamo electoral.

Esta primera conclusión explica uno de los elementos básicos de la interpretación del Partido Popular que, textual y repetidamente, utilizó los términos «desafío», «reto» y «órdago» al Estado constitucional para referirse a la actitud del nacionalismo gobernante y de ETA. Ahora bien, el Partido Popular no se limitó a denunciar la dimensión nacionalista del desafío, sino que - además de dar por hecha la unidad y la sustitución de ETA por los partidos nacionalistas - añadió la colaboración objetiva del socialismo a través de sus pactos, de su debilidad y de su división ideológica. De esta manera exageró el riesgo que se avecinaba con algo parecido a un contubernio socialista-nacionalista hasta el extremo de convertirlo en un problema de Estado de tal envergadura que sólo lo solucionaría una victoria popular por mayoría absoluta. Así, el desafío, por real que fuese, se convirtió en un arma electoral. Los análisis de los editoriales comentaron y criticaron con su incorregible lenguaje críptico ésta y otras desmesuras cometidas por los partidos.

Frente a esta interpretación, y en total ruptura con la línea seguida por la anterior dirección del socialismo vasco, el Partido Socialista en comunión con todos los demás partidos que en este trabajo se mencionan - con la salvedad de que el PNV hacía al PSOE acreedor de algunas críticas funda-

Madrid los nacionalistas vascos y catalanes destierran de su vocabulario la palabra Madrid como sinónimo del mal» (El Correo 13-3-04 (35), «Una hermosa lección». 
mentales dirigidas contra el PP - defendió la interpretación - sin utilizar expresamente los términos de desafío ni reto y con la expresa oposición a los planes del nacionalismo vasco gobernante-, de que el desafío ya lo había realizado el Partido Popular y que lo seguiría realizando contra la democracia, el autogobierno y las libertades y creando cada vez más nacionalismo y más crispación, si no se le ganaba en las elecciones. Esta interpretación, que situaba el problema en la derecha española, era tan electoralista como la realizada por el Partido Popular y superaba la legítima crítica, que podía hacerse y se hizo a determinadas políticas seguidas por el Partido Popular en el Gobierno, y supuso una mayor alteración de la realidad. También los editoriales - con las mismas limitaciones - y algunos comentarios, éstos con mayor precisión, destacaron y censuraron esta interpretación.

Los editoriales pasaron de puntillas o no aludieron a esta cuestión del desafío nacionalista. No había más reto que el del terrorismo de ETA y, con respecto a los demás nacionalismos, sólo se insistió en la necesidad de la unidad de todos los partidos y en el rechazo del diálogo con ETA. Su denuncia fue substancialmente contra el nacionalismo terrorista, donde estaba el verdadero reto al Estado constitucional, y secundariamente contra las dudas, los apoyos y las simulaciones de los partidos nacionalistas. Por el contrario, los comentaristas, que se salieron de las cuestiones puntuales de las elecciones, extendieron el peligro de ETA a la política del Gobierno Vasco, a los partidos nacionalistas gobernantes y al fanatismo ideológico que los fundamentaba, concluyendo que todo ello constituía la raíz de los problemas del País Vasco. Lo novedoso de esta interpretación estaba en la ampliación del concepto de problema hasta cuestiones sociales, económicas, morales e ideológicas.

Y, por último, hay que resaltar el pésimo criterio que los partidos mostraron del electorado, al que con un gran descaro dirigieron sus planteamientos basados más en la supuesta estupidez o credulidad de los ciudadanos que en la rigurosidad de sus argumentaciones. Todos los partidos forzaron la realidad en una clara pretensión de manipular al electorado. El PP y el PSOE lo hicieron forzando la realidad del momento, mientras que el nacionalismo lo hizo desde su inmutable y fundamentalista sistema de creencias. 